
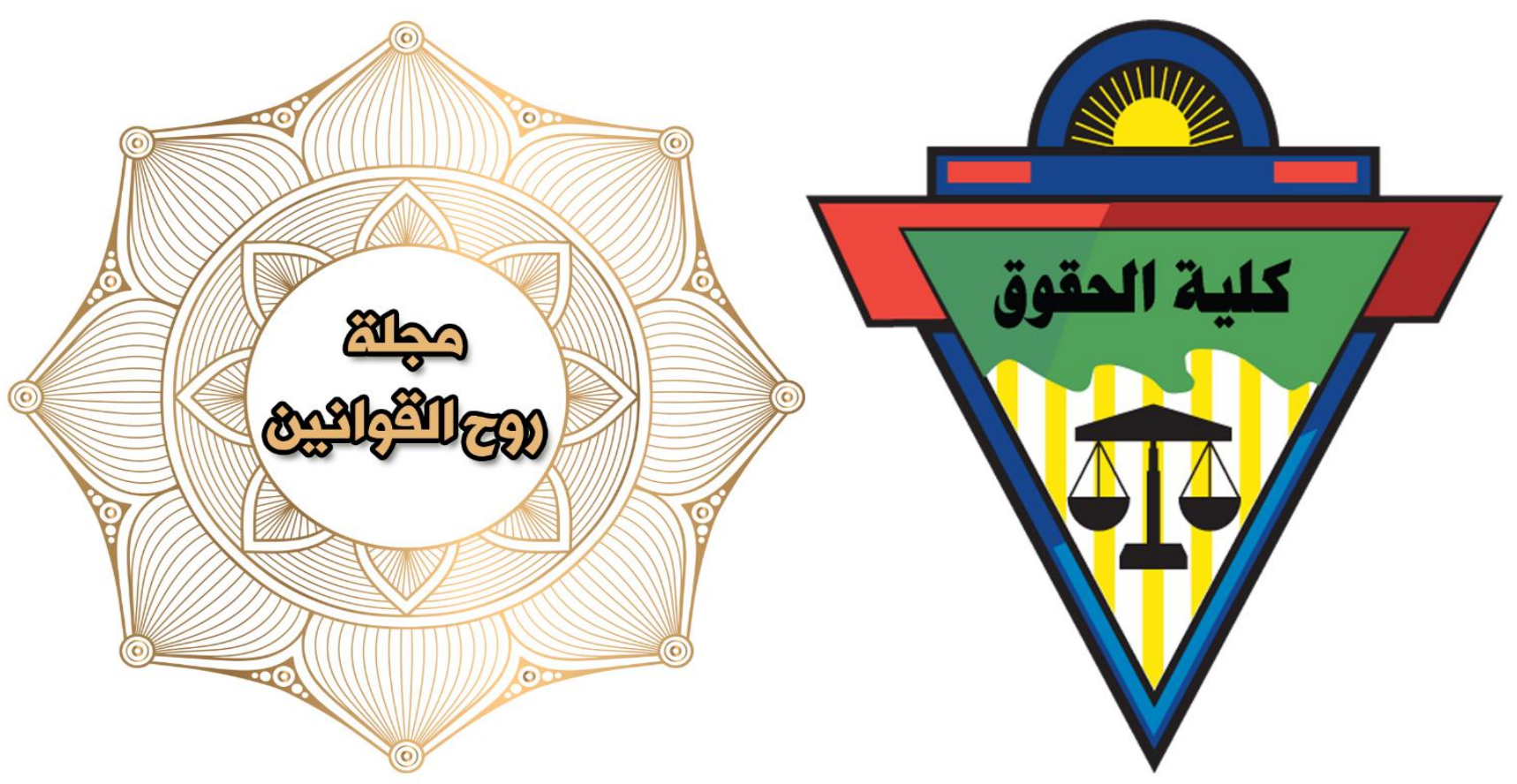

العنوان : تعويض الأجنة عن الأضرار المدنية دراسة مقارنة بين القانون المدني المصري ، و الشريعة الإسلامية .

الناشر : مجلة روح القوانين - كلية الحقوق - جامعة طنطا .

المؤلف : محمد حمدان عابدين ·

المجلد : الثانى . n - n

العدد : الثامن و الثمانون .

محكمة : نعم .

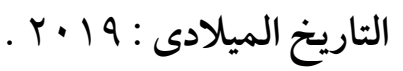

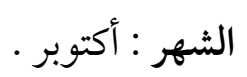

الصفحات : r -

مواضيع : تعويض الأجنة - الأضرار المدنية .

C 9 ـ ـ مجلة روح القوانين - جميع الحقوق محفوظة . 
الحمد الله الذي خلق الإنسان من سلالة من طين، ثم جعله نطفة في قرار مكين، ثم سوّاه ونفخ

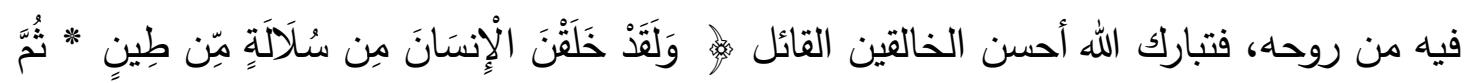

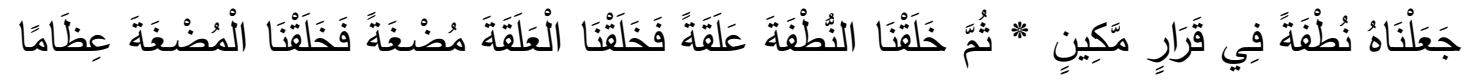

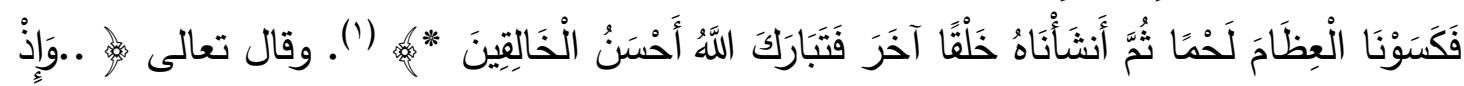

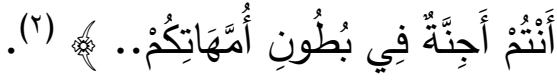
لقد جعل الإسلامُ للطفل حقوقًا منذ بَذْع تكوينه في هذه المرحلة وهو في بطن أمه، فحافظ عليه

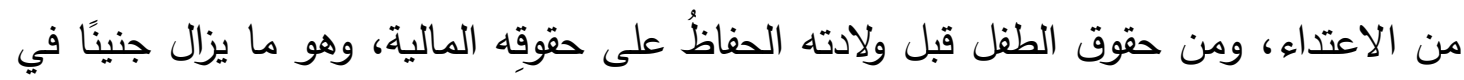

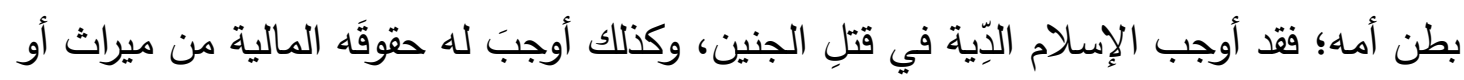

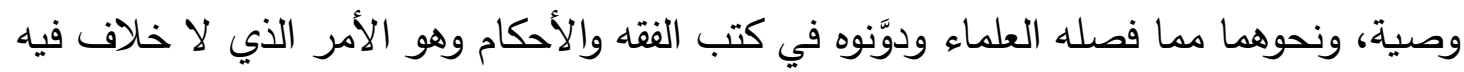

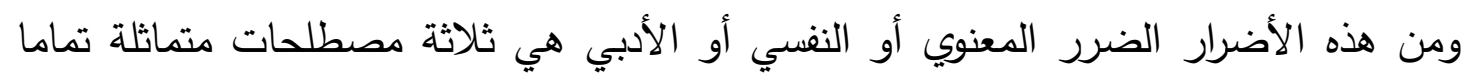

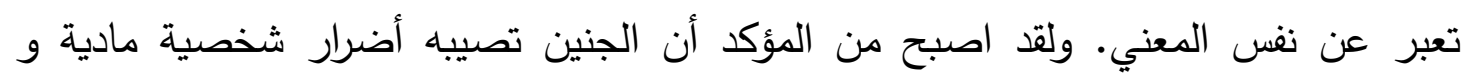

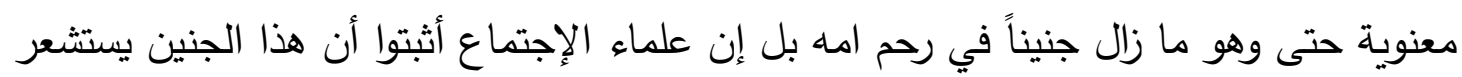

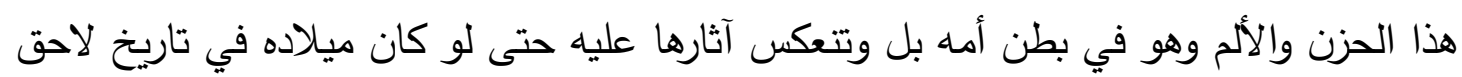

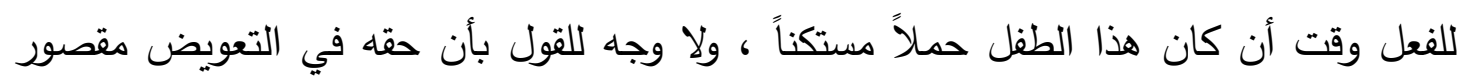

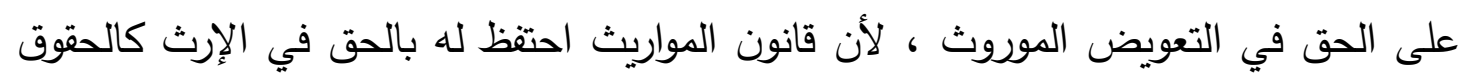

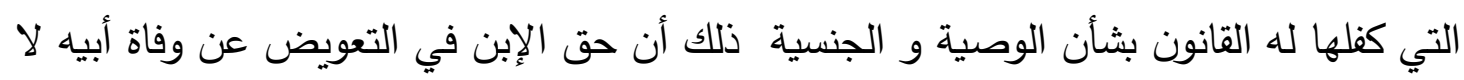

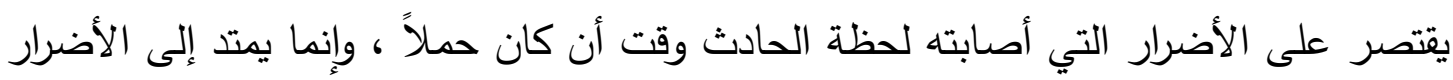

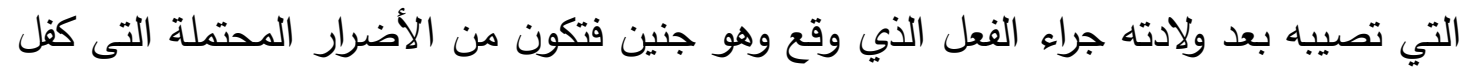

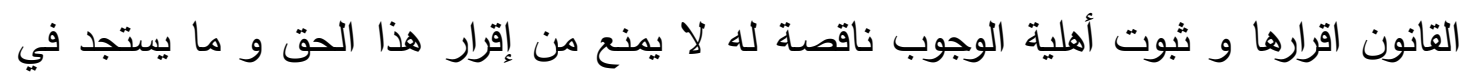

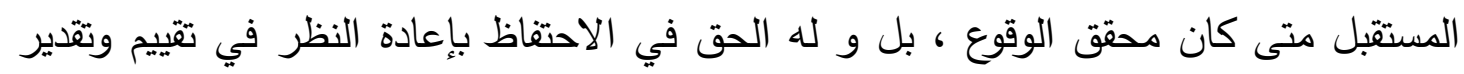
هذا الضرر .

فمن حقوق الطفل قبل الولادة الحفاظُ على حياته وهو جنين في بطن أمه، وقد جعل الإسلامُ للطفل حقوقًا منذ بَذْع تكوينه في هذه المرحلة وهو في بطن أمه، فحافظ عليه من الاعتداء (r).

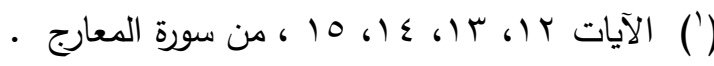

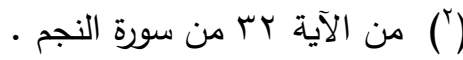

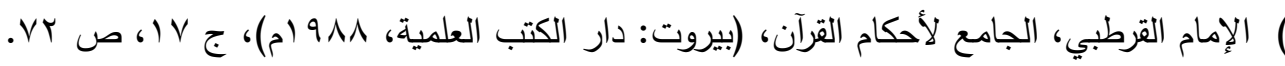


ومن حقوق الطفل قبل ولادته الحفاظُ على حقوقِه المالية، وهو ما يزال جنينًا في بطن

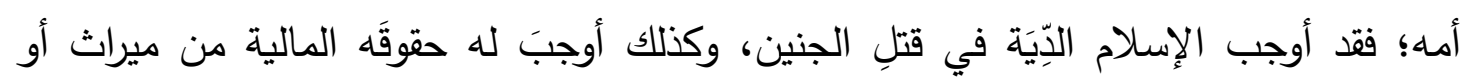

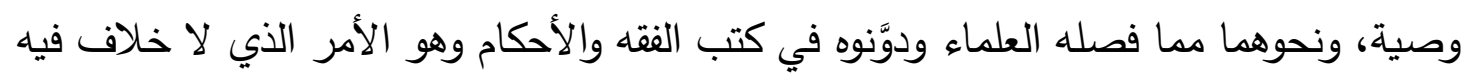

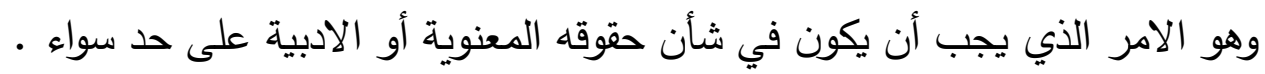

\section{المشكلات التي يناقشها موضوع البحث:}

لا يخفى على كثيرين الجدل الفقهي والقضائي حول الإعتراف للجنين بالذمة المالية

والأهلية الددنية التى تكون الثخصية القانونية له وكذا حقه في تعويض الأضرار المادية والأدبية له حال الاعتداء عليه وهو في طور التكوين .

ولكون للجنين شخصية مستقلة ومتميزة عن أمه فإن الإعتراف بالاستقلالية هذا يعطيان له مركزًا

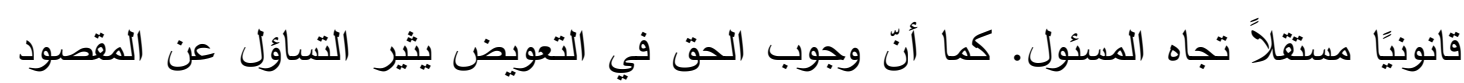

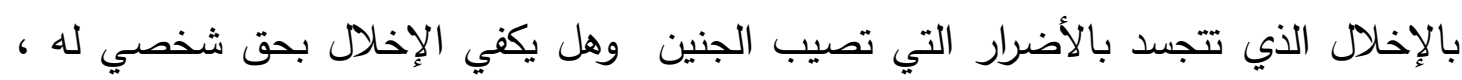

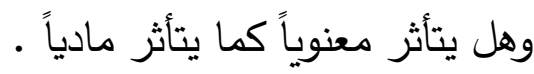

\section{أهمية موضوع الدراسة:}

تتمثل أهمية هذه الدراسة في كونها تساهم في تقديم حلول لبعض مشكلات نظرية

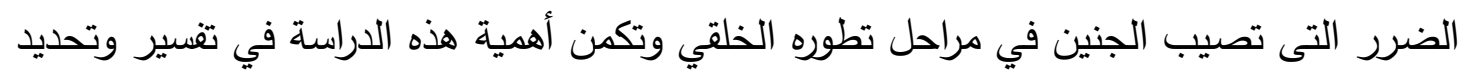

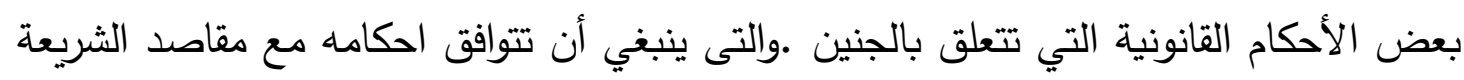

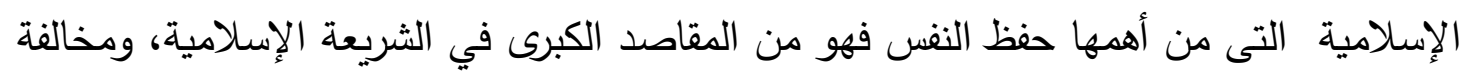

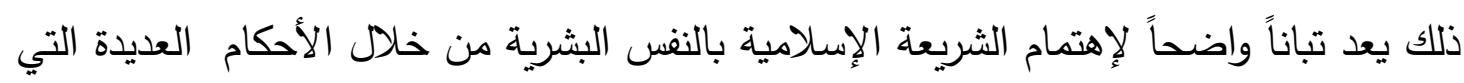

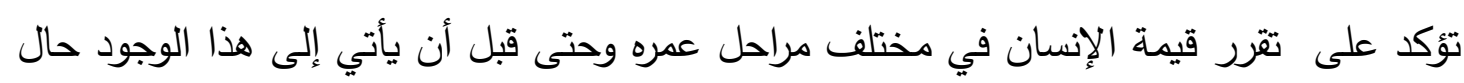
كونه جنيناً .وحقه في الحياة

منهج الاراسة:

اعتمد الباحث في هذه الدراسة على منهجين : وذلك على النحو الآتي:

أولاً: المنهج المقارن

وذلك من خلال عرض موقف الفقه والقضاء المقارن، وكذا موقف الفقه الإسلامي في تطبيق

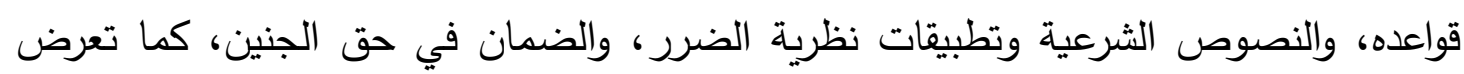
الدراسة القوانين المقارنة وفى مقدمتها القانون المدني المصري، والقانون الفرنسي، والقانون الإنجليزي، وكذا القوانين العربية التي أقرت تعويض الجنين سواء في صورتها المادية أو الأدبية. 
كان اللجوء إلى المنهج الاستتباطي بهذف التعرض للنصوص القانونية المتعلقة بموضوع تعويض ضرر الذي يصيب الجنين ومدأ ملائمة النصوص لحل المشكلات القانونية حيال إقرار

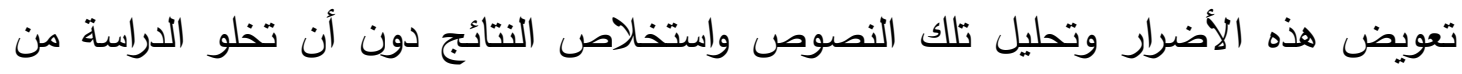

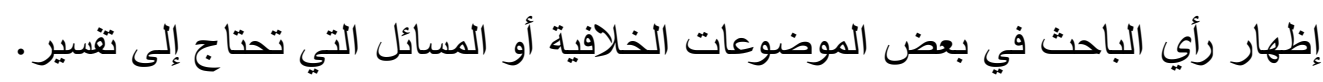
خطة البحث: تم تقسيم هذه الدراسة إلى :.

مقدمة

المبحث الأول : التعريف بالجنين والتعويض عنه

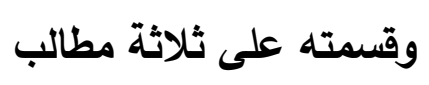

المبحث الثاني : شروط استحقاق الجنين للتعويض مطاب

$$
\text { وقسمته الى مطلبين: }
$$

المبحث الثالث : أهلية اكتساب الجنين للتعويض

$$
\text { وقسمته الى ثلاثة مطالب : }
$$

المبحث الرابع :موقف القضاء من تعويض الجنين

$$
\text { وقسمته الى مطلبين : }
$$

المبحث الخامس :انواع الأضرار التى تصيب الجنين ويمكن التعويض عنها

$$
\text { وقسمته الى مطلبين : }
$$

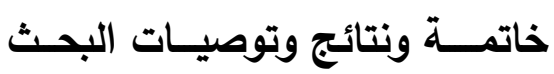

دكتور : محمد حمدان عابدين

الأستاذ المساعد بكلية العلوم الإدارية قسم الأنظمة

جامعة نجران المملكة العربية السعودية 
تعويض الأجنة عن الأضر ار المدنية دراسة مقارنة بين القانون المدني المصري ، والشريعة الإسلامية

\section{المبمث الأول : التعريف بالجنين والتعميض عنه}

تمهيد وتقسيم لما كان الجنين في طور النمو تطلب الامر التعريف بالجنين لغة واصطلاحاً ، وكذا تعريف التعويض ، وبيان مفهومه في حق الجنين وأنواعه ، ومن ثم تطلب تقسيم المبحث

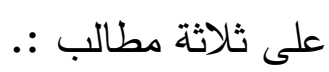
المطلب الأول: التعريف بالجنين المطلب الثاني : التعريف التعويض المطلب الثالث : مفهوم التعويض فى حق الجنين وأنواعه

\section{المطاب الأول}

\section{التعريف بالبنين}

الجنين لغة: جاءت لفظة الجنين من مادة "جن وجنن"،. وهي تعني في أغلبها الإستتار والاختفاء. والجنان بالفتح هو القلب لاستتاره ـ في الصدر فقد جاء في لسان العرب لابن منظور، أن الجنين سمي بهذا الاسم لاستتاره في بطن أمه،.ومنه إذا قلنا: جن الثيء يجنه جنا أي ستره، وجن عليه الليل أي ستره. والجنن بالفتح هو القبر لستره الميت، وهو أيضا الكفن، والجنين: المقبور ، ، والجنين الولد ما دام في بطن أمه، وجمعه أجنة وأجنن. ('). كما جاء في معنى الجنين أجن الثيء في صدره أي أكنه وأجنت المرأة ولداً ، والجنيني الولد ما دام في البطن ، وجمعه أجنه (r). مثل دليل وأدلة (l)

(') محمد بن مكرم بن منظور الأفريقي المصري، لسان العرب، الطبعة الأولى، دار صادر ، بيروت، دون تاريخ

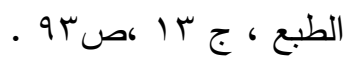

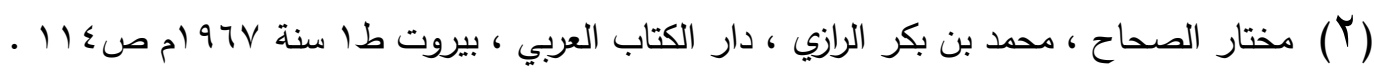


والتعريف الاصطلاحى للجنين : هو الولد ما دام في البطن (؟). وفي هذا يرى الفقه الحنفي: انه لا يحكم على ما في الرحم بأنه جنين ، حتى يستبين بعض خلقه ، فإن ظهر فيه شيء من آثار النفوس فإنهم يحكمون عليه بأنه ولد _ جنين _ اما اذا لم يستبين فيه شيء من الآثار فهذه علقة أو مضغة أو دم جامد لا يدرى حقيقته ندهم (").وقيل أن الجنين على وزن فعيل بمعنى مفعول مجنون اي مستور من جنه اذا ستره والجنين اسم الولد في بطن الأم ما دام فيه والجمع

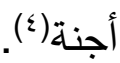

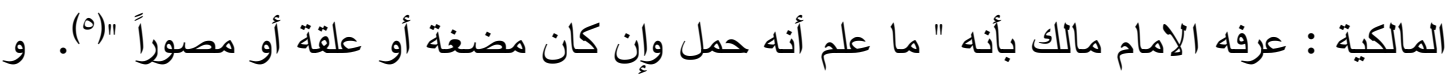

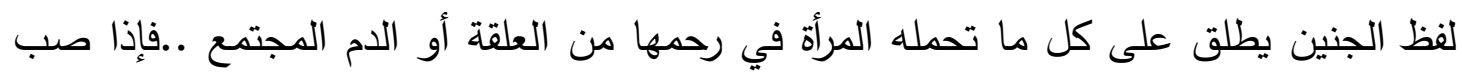
الماء الحار على هذا الدم ولم يذب فيه فهو جنين فإذا ذاب فليس بجنين (־). وعرفه بعض الماليكة بأنه " كل ما طرحته المرأة مما يعلم أنه ولد سواء أكان تام الخلقة أم كان

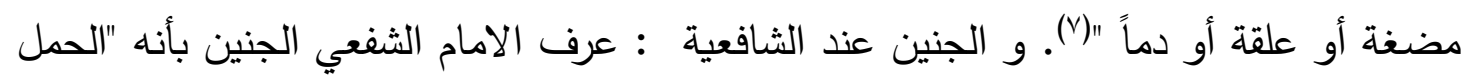

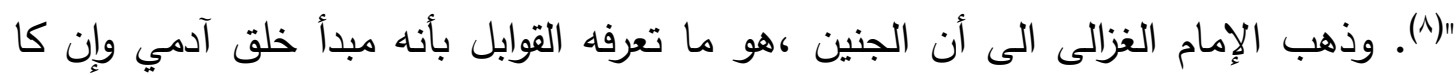

$$
\text { المصباح المنير ، احمد بن محد اليومي ، مكتبة البنان ، بيروت ط اسنة 19Av م صب؟ . }
$$

(")الجامع لأحكام القرآن " للإمام شمس الدين ابي عبدالله محمد بن احمد بن ابى بكر بن فرج الانصاري

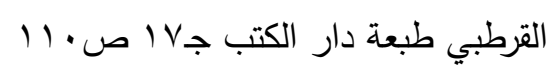
(") المبسوط شمس الدين السرسخي دار المعرفة بيروت جr صبَ آץ ؛ البحر الرائق كنز الدقائق ابن نجيم

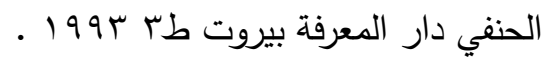

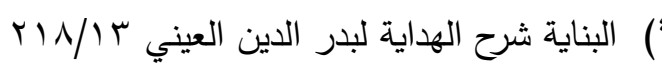

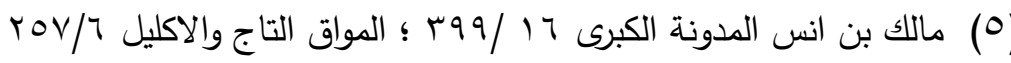
(7) الخرشي على مختصر سيدي خليل وحاشية الثيخ على العدوي على الخرشي ، دار الكتاب الاسلامي ،

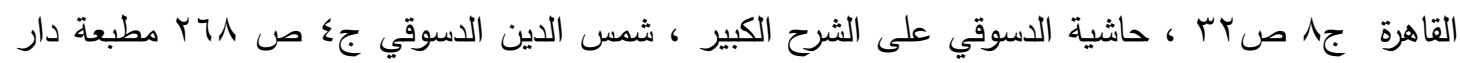
احياء الكتب العربية .

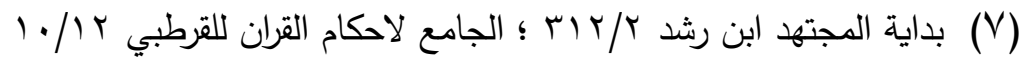

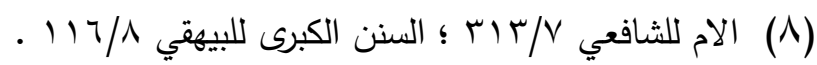


تعويض الأجنة عن الأضرار المدنية دراسة مقارنة بين القانون المدني المصري ، والشريعة الإسلامية

مضغة أو علقة سواء تصور فيه صورة آدمي او لم يتصور بشرط أن تقول القوابل .. أما اذا

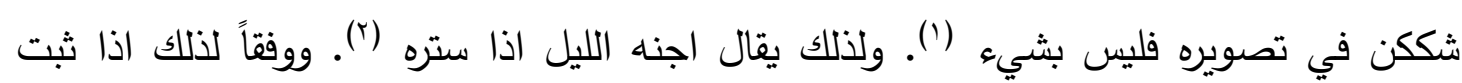
تصور الجنين استحق الضمان فإن قام الثك فلا ضمان ويرئ الحنابلة أن بداية الجنين تكون مع بداية تكون صورة الآدمي فيه اما قبل ذلك فلا يعلم أنه

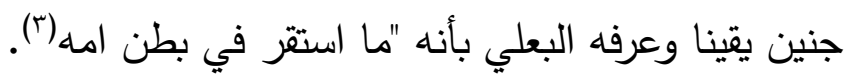
قال تعالى واذ أنتم اجنة. وقوله صل ان احدكم يجمع في بطن امه.

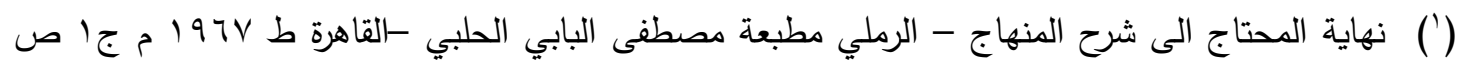

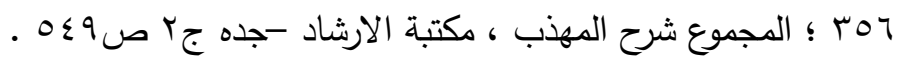

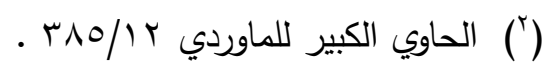

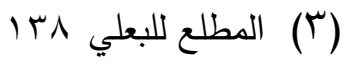




\section{الإنب الثاني}

\section{التعريف بالتعويض}

وجاء في لسان العرب: العوض البدل والجمع أعواض، عاضه منه وبه والعوض:

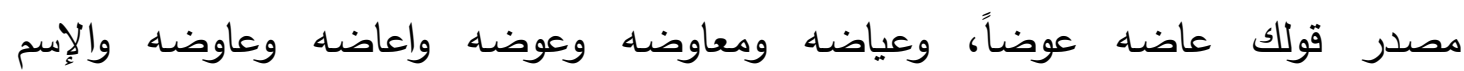

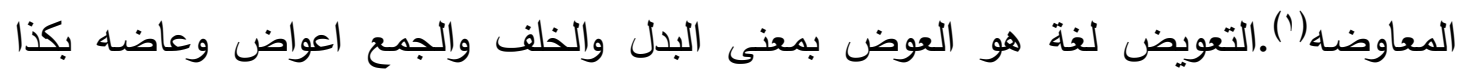

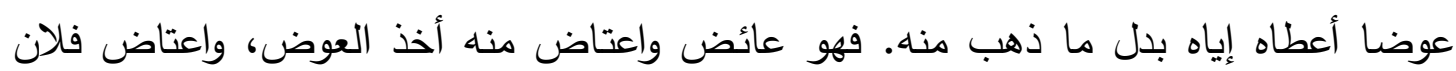

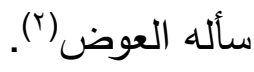

يعرف الضمان بمعنى التعويض بأنه إعطاء مثل الثيء أن كان من المثليات وقيمته إن

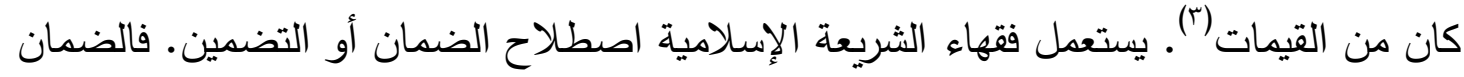

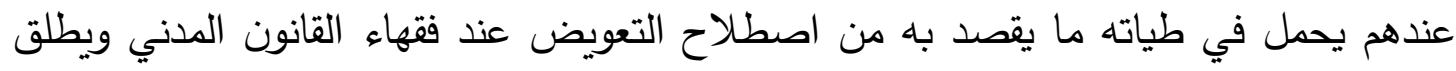

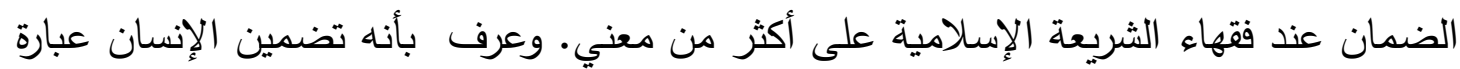

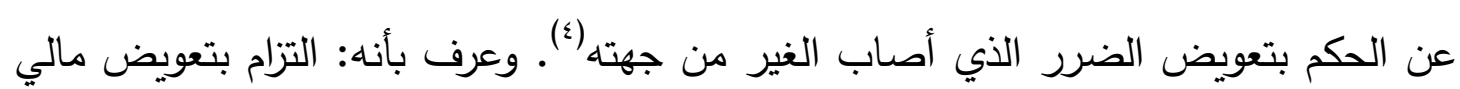

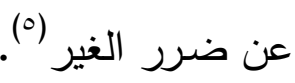
الأول: الضمان بمعنى الكفالة وهو خارج عن نطاق موضوعنا الثاني: الضمان بمعنى التعويض وهو ما سوف نتتاوله بالبحث والدراسة

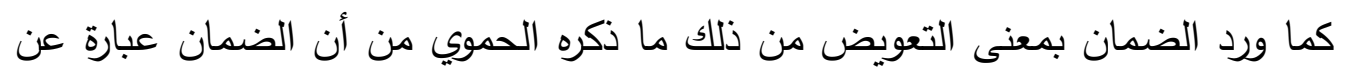

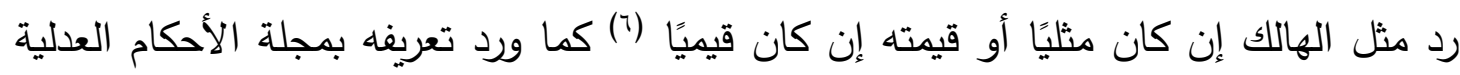

(') لسان العرب -لابن منظور طبعة الدار المصرية للتأليف والترجمة صد 00 .وكذا طبعة دار إحياء التراث

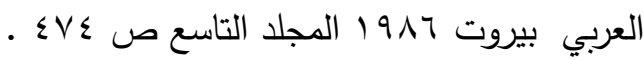

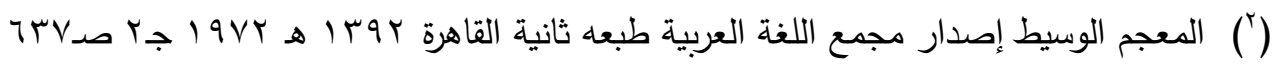

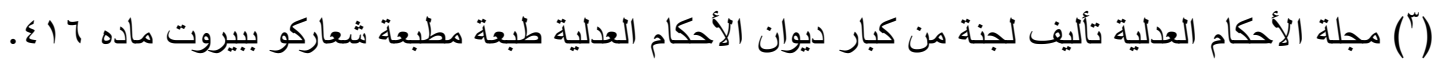

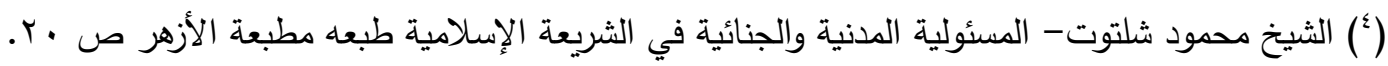

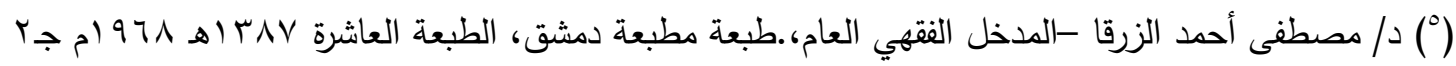

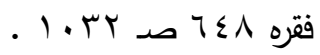

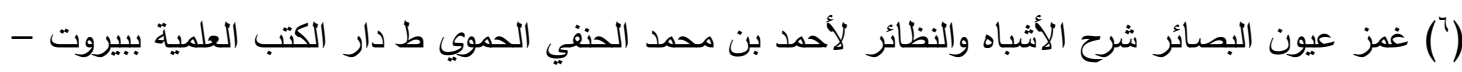

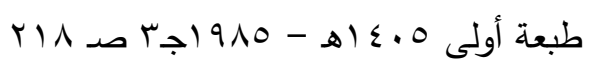


تعويض الأجنة عن الأضرار المدنية دراسة مقارنة بين القانون المدني المصري ، والشريعة الإسلامية

بأنه إعطاء مثل الثيء إن كان من المثليات وقيمته إن كان من القيميات. (') وذكر الثيخ على الثلى

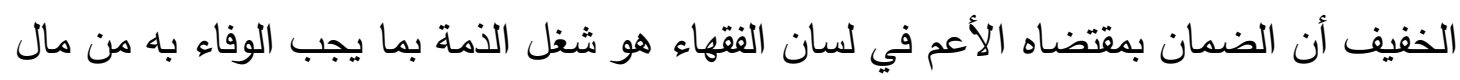

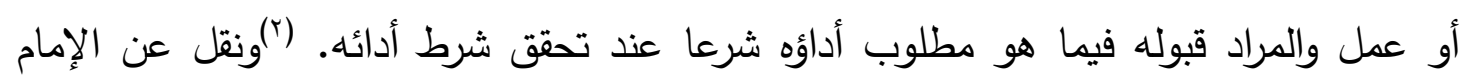

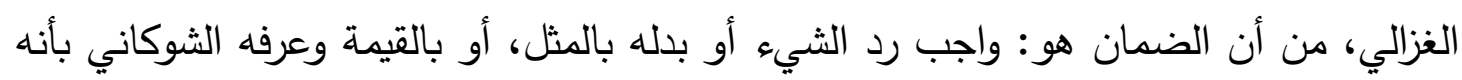

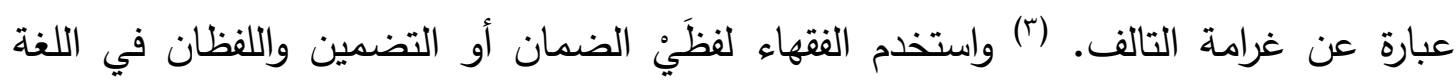
بمعنى واحد فيقال: ضمنته المال وبه ضماناً فأنا ضامن وضمين, ضمنته المال ألزمته إياه,

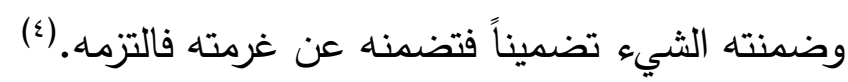

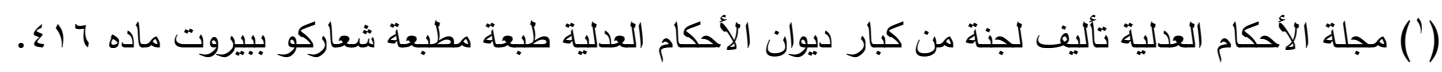

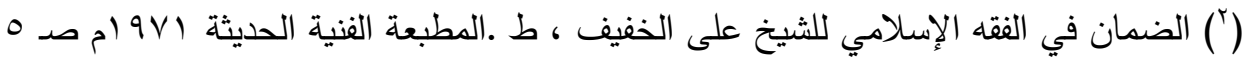

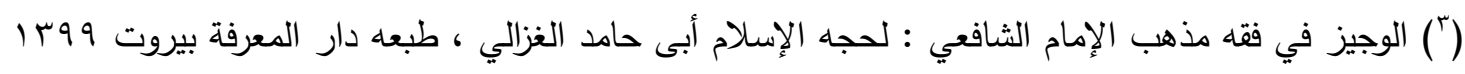

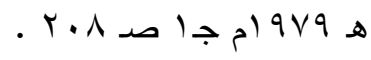

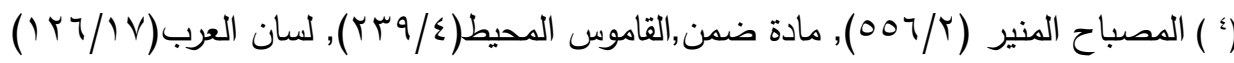




\section{الالمبلب الثالث}

\section{هفهوم التعويض فى حق الجنين وأنواءه}

التعويض هو مايلتزم به المسئول فى المسئوليه المدنيه تجاه من اصابه ضررفهو جزاء المسئوليه (')، وقيل هو جزاء المسؤولية المدنية بنوعيها العقدية والتقصيرية، ويهدف إلى جبر الضرر الذي هوني لحق بالمضرور وعرف بأنه ما يعطى للمرء مقابل ضرر لحق به (广)،جبر وازالة الضرر الناشئ عن المسئوليه الددنيه واعادة المضرور الى الحاله التى كان عليها قبل وقوع الضرر. وبذلك يرتبط التعويض بالضرر ، ويقيم على اساسه اعمالا للقاعده (r)، والحكم بالتعويض يكون باعادة المضرور الى ما كان عليه قبل وقوع الضرر ما امكن ، والا كانت الاعاده بالتضمين ، وهو الحكم بالضمان وذلك يكون بالزام المعتدى بمثل ما اتلفه من المال او بقيمته. ان التعويض هو

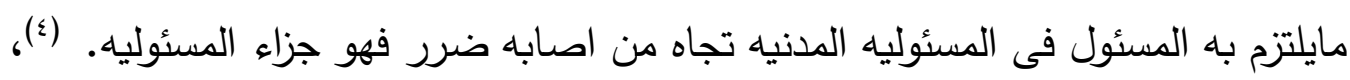
التعويض المعنوي يشمل التعويض النفسي نتيجة الاهانة او التعرض لحادث او الثتم والتحقير من قبل الغير الضرر الذي لا يصيب الثخص في ماله وإنما يصيبه في حسه وعواطفه (ه)، وعرف بأنه: الضرر الذي يصيب الثخص في شعوره أو عاطفته أو كرامته(آ).

اما التعويض المادي في حق الجنين : فهو التعويض الجسدي والتعويض المالي عن

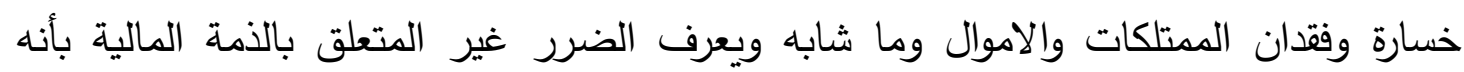

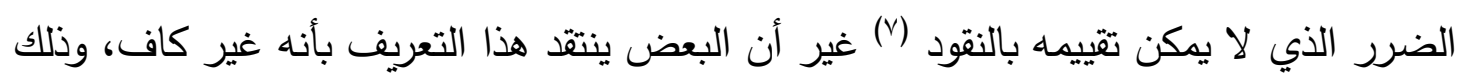

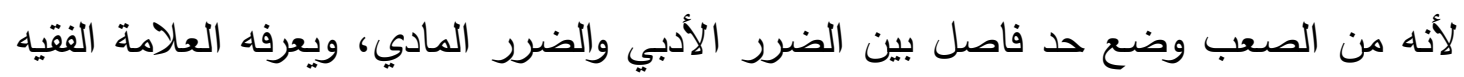

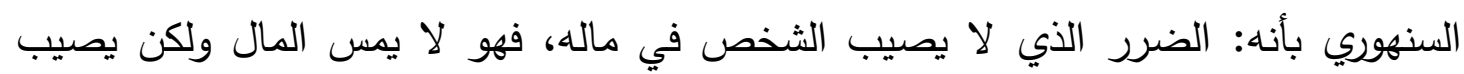

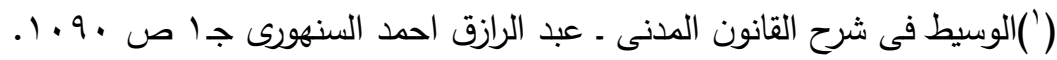

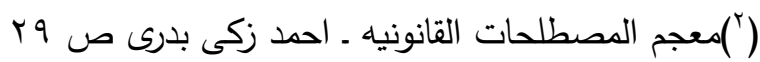

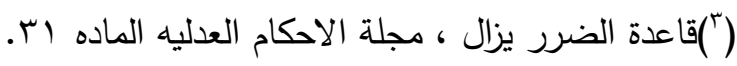

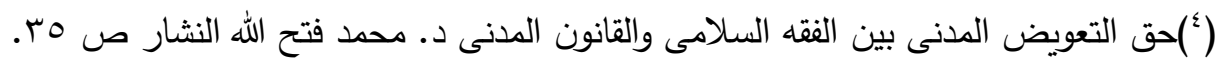

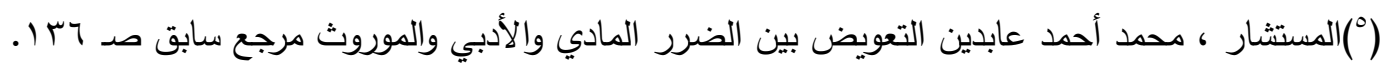

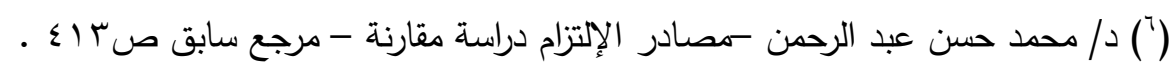

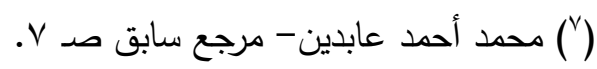


مصلحة غير مالية(1)، ويعرفه الدكتور محمد إبراهيم دسوقي بأنه: كل إخلالٍ بمصلحة أدبية

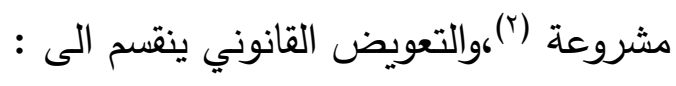

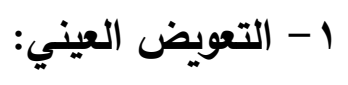

التعويض العيني معناه إزالة الضرر الذي اصاب الجنين عيناً أي إعادة المتضرر عن هذا الطريق إلى الحالة التي كان عليها قبل وقوع الفعل الضار ويفرق البعض بين التعويض العيني وبين التنفيذ العيني المعروف في المسئولية العقدية والذي يعني قيام المدين بتنفيذ ما التزم به عيناً ذلك أن التعويض العيني لا يعني سوى حصول المتضرر على بديل عن عين حقه الذي انتهك بالفعل الضار في حين أن التنفيذ العيني يعني حصول الدائن على عين حقه وليس على لئ بديل عنه في حين لا يفرق البعض الآخر بين الاثثين بل يعتبر أن التتفيذ العيني والتعويض بلين العيني مفهومان مترادفان فيقول البعض أن التعويض العيني أو التتفيذ العيني هو الوفاء بالالتزام عيناً ويقع هذا كثيراً في الالتزامات العقدية أما في المسئولية التقصيرية فيمكن كذلك في قليل من المفروض أن يجبر المدين على التتفيذ العيني(")

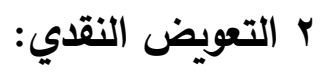
في معظم حالات المسئولية التقصيرية الذي يتعرض فيه الجنين للضرر يكون التعويض النقدي هو الملجأ الأخير والوحيد لجبر الضرر خاصة عندما يتعذر الحكم التعويض العيني وهذه لهن الصفة الغالبة للتعويض هي التي دفعت المشرع إلى النص عليه وكأنه القاعدة العامة من

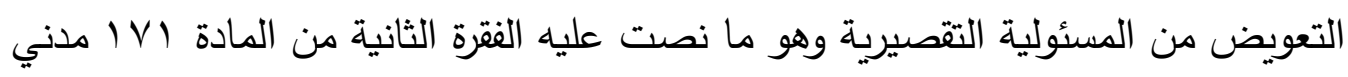
مصري (๕)، من (ان)

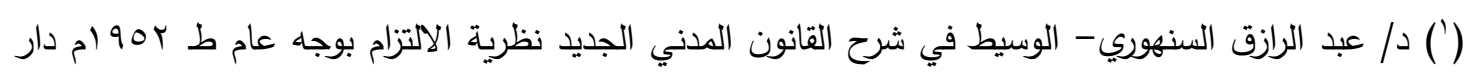

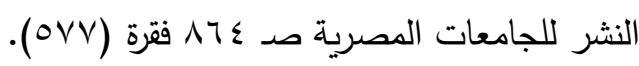

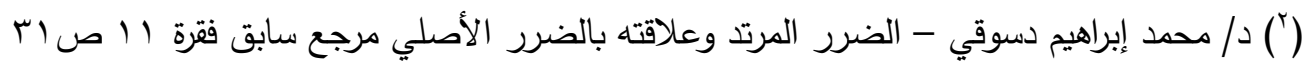

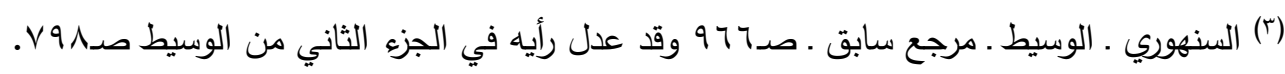

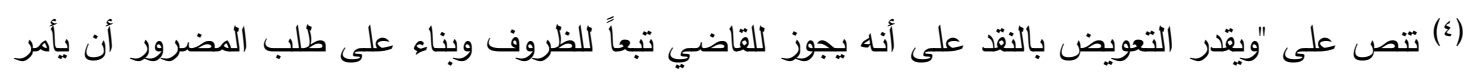
بإعادة الحالة إلى ما كانت عليه وذلك على سبيل التعويض". 
قد يستعصى في بعض الحالات التعويض العيني والنقدي ولا يبقى إلا التعويض غير النقدي ويبرز ذلك في التعويض الأدبي فالمتضرر بإمكانه المطالبة بإصلاح ضرره الأدبي على سبيل المثال عن طريق نشر الحكم في إحدى الصحف أو المجلات ، وقد تأمر المحكمة بنشر بحكم القاضي بإدانة المدعى عليه في الصحف وعلى نفقه الأخير (') أو إذاعته عن طريق وسائل الإعلام الأخرى كالمذياع والتلفاز أو بتعليق صورة منه في مكان بارز في محل العمل أو لوحة إعلانات مكان عام وبهذا الخصوص ذهبت محكمة النقض المصرية في أحد قراراتها إلى أن تعويض الضرر الأدبي بنشر الحكم في الصحف على نفقة المحكوم عليه من سلطة قاضي الدعوى التقديرية والمطلقة بما لا رقابة لمحكمة النقض على محكمة الموضوع فيه والتعويض بهذه الصورة مقبول في حق الجنين خاصة في الاضرار الأدبية التى تصيبه كتشويه سمعته بانكار نسبه مثلا ـ فقد يكفى في التعويض عن الضرر المعنوي نشر الحكم بطريق اللصق أو الإعلان على نفقة المسئول وهو ما يؤكده الفقه في مصر (r).

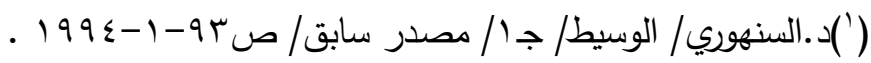

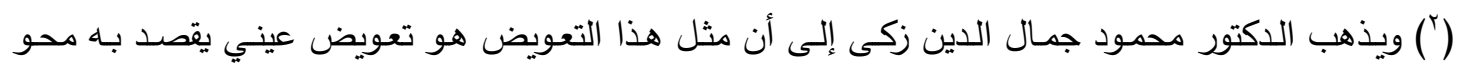

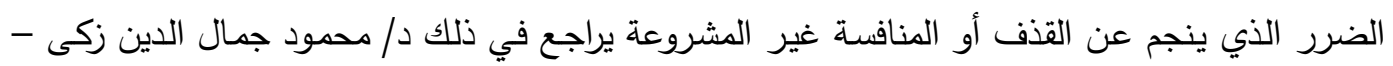

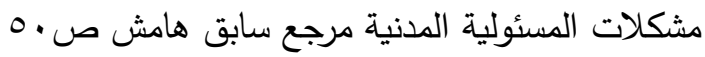




\section{البمث الثاني}

\section{مشروعية استمقاق الجنين للتعويض وبيان شروطه}

في ظل الاعتراف بمشروعية الجنين للحصول على تعويض حال الاعتداء عليه كان

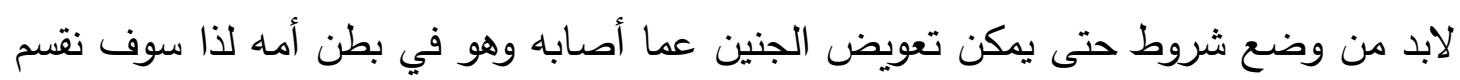

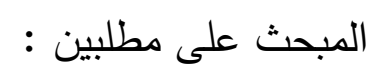

المطلب الأول : مشروعية تضمين ضرر الجنين المطلب الثاني: شروط استحقاق الجنين للتعويض

\section{الإhلب الأول}

\section{مشروعية تضمين ضرد المنين}

لا خلاف في ثبوت مشروعية تضمين الضرر في الفقه الإسلامي والقانون الوضعي فالمصلحة التي يعد الإخلال بها ضرراً يستوجب التعويض هي المصلحة المشروعة، أما

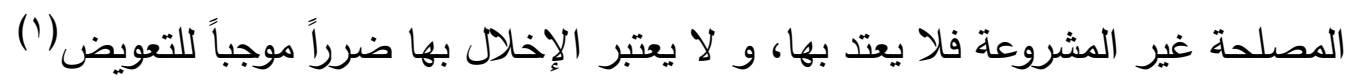
أن التعويض لا يشمل إلا الأضرار المباشرة سواء في المسئولية العقدية أو التقصيرية وعليه فإن

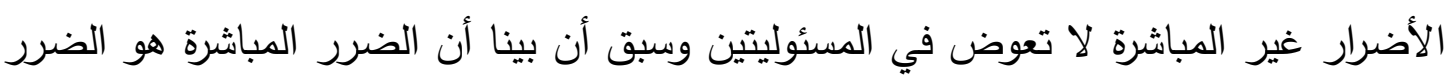

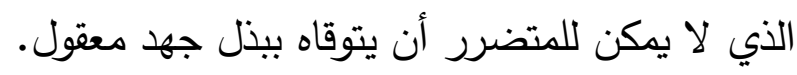
كما أن التعويض لا يقتصر فقط على ضمان الخسارة التي حلت بالجنين جراء الفعل الضار وإنما

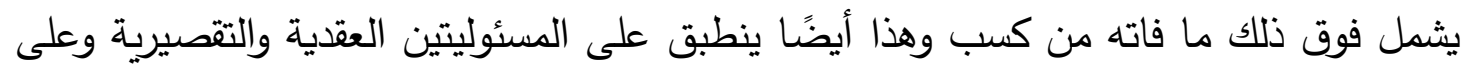

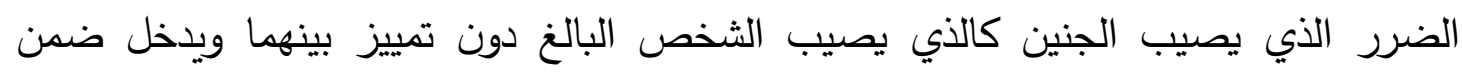

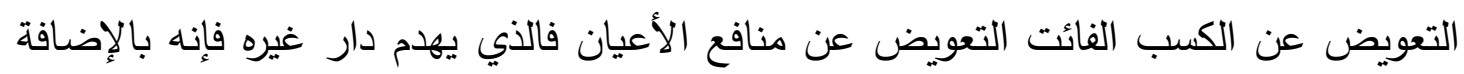
إلى قيمتها يضمن بدل منفعتها التي فوتها على صاحبها (r).

والجدير بالذكر أن التعويض في المسئولية التقصيرية لا يقتصر على الضرر المباشر

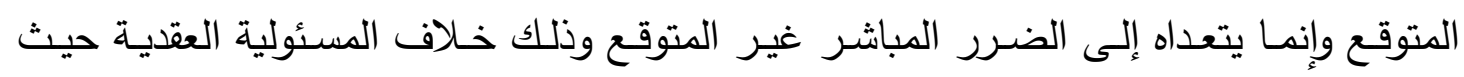

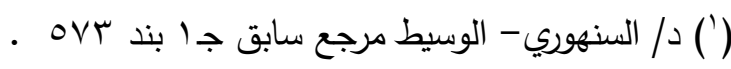

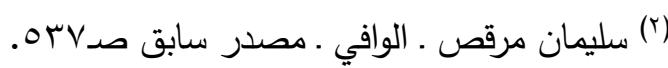


يقتصر التزام المسئول فيها بالتعويض عن الأضرار المباشرة المتوقعة فقط .كذلك فإن التعويض عن الكسب الفائت لا يحكم به إلا إذا طلبه المتضرر بشكل صريح' .وهذه العناصر تؤخذ في الاعتبار عند تقدير التعويض الذي يستحقه الجنين

والفقه الاسدلامي : لا يفرق في ذلك بين الجنين ناقص الأهلية أو غير كامل الأهلية فقد أنـاط الفقـه الإسـلامي الضــمان عن الضـرر إعمـالاً لقاعدة لا ضـرر ولا ضـرار الثابتة بالحديث النبوي قال "صلى الله عليه وسلم" لا ضرر ولا ضرار (r) وقوله ـ صلى الله عليه وسلم ـ حرمة مال

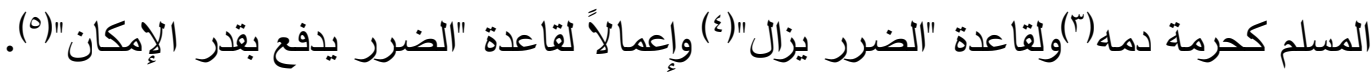
وعن أبى بكرة رضي الله عنه أن النبي صلى الله عليه وسلم قال في خطبته يوم النحر بمنى: إن دماءكم وأموالكم عليكم حرام كحرمة يومكم هذا في شهركم هذا في بلدكم هذا(؟). والفقه الإسلامي قد عرف الضرر بأنه إلحاق مفسده بالغير مطلقًا(V) مما ينفى الضرر في مقابلة الضرر وذلك بتضمين الضار جبراً لما فوت على المضرور من حق. (^) وهذه قاعدة عامة يترتب عليها أنه لا يجوز لأحد أن يبادئ أحداً بضرر بغير وجه حق، ولا أن يقابله به فلو أن

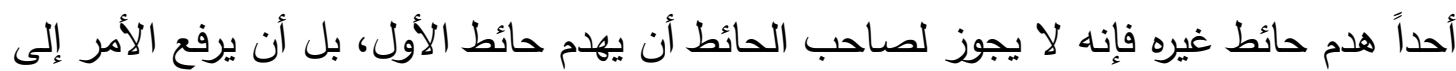
الحاكم فيضمّنه قيمة الحائط الذي هدمده(9).

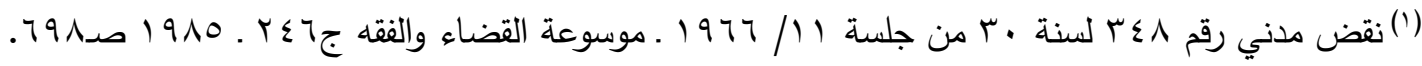
(') (اوواه البخاري ومسلم ومالك في موطئة وقال الحاكم في المستدرك أنه صحيح الاسناد وقال عنه الدار قطني أنه حديث حسن - النووي شرح الأربعين النووية لابن دقيق العيد- القاهرة طبعة السلام العالمية صـ 01 اومسند

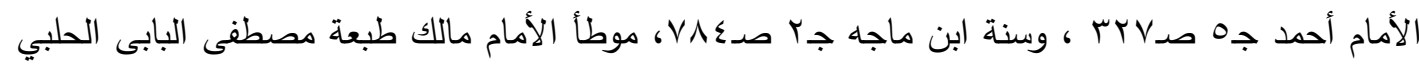

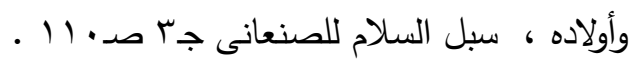

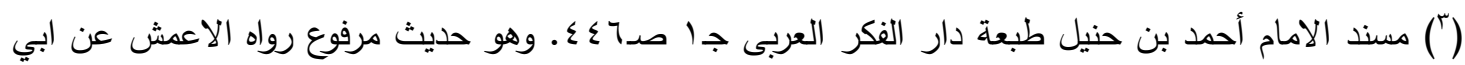
وائل عن عبد الله بن ابي مسعود يراجع سنن الدار قطني والبحر الزخار بمسند البذار

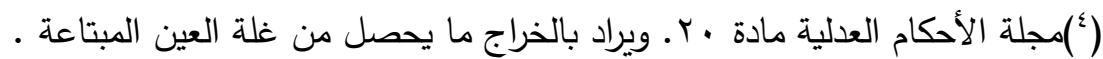

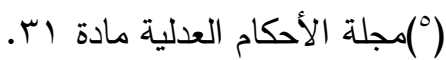

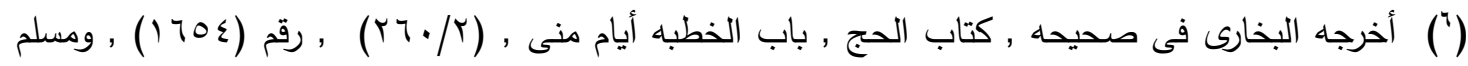

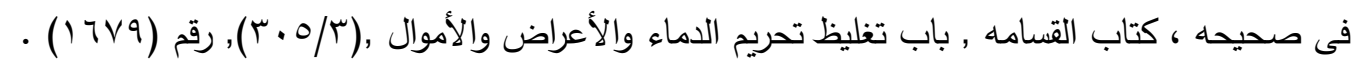
( ل) يراجع في ذلك فتح المبين ، لثهاب الدين ابى عباس احمد بن محمد بن على بن حجر الهيثمي ،دار احياء الكتب العربية - طبعة ror ( (المدخل للفقه الإسلامى، للدكتور محمد سلام مدكور ، طبعه مكتب عبد الله وهبه القاهرة طبعة أولى ع 90 ام هربه

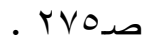

(9)شرح المجلة، لسليم بن رستم باز اللبناني، طبعة المطبعة الأدبية، بيروت 191 ام طبعة ثانية شرح المادة 19 


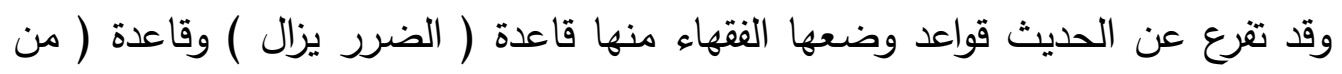

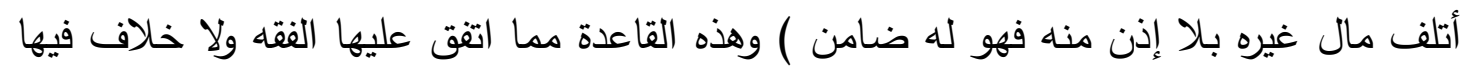

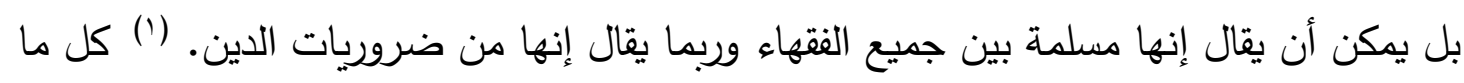

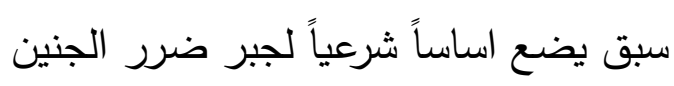

وأدلة مشروعية ضمان ضرر الجنين نجد سردها في الكتاب والسنة ففي الآيات القرآنية

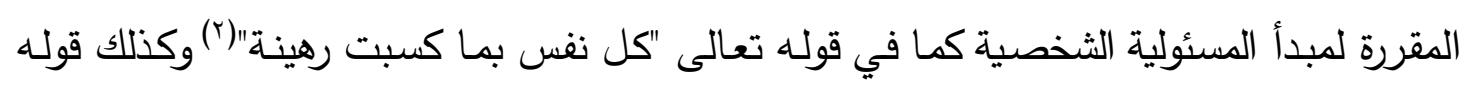

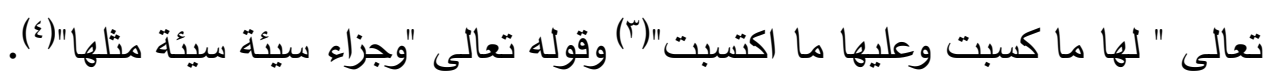
كما نجدها في حديث رسول الله _صلى الله عليه وسلم_ الخراج بالضمان وعلى هذا الأساس ثم وضع القواعد في علم أصول الفقه فان. فقد ذكر الثيخ شلتوت: أن تضمين الإنسان عبارة عن الحكم بتعويض الضرر الذي

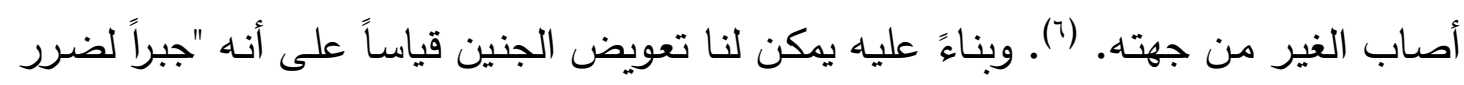
الجنين عما أصاحبه من نقص في النفس أو الذات "(V).

وتطبيقات الضمان في فروع الفقه نجدها تقوم على مبدأين عامين الأول: هو مسئولية

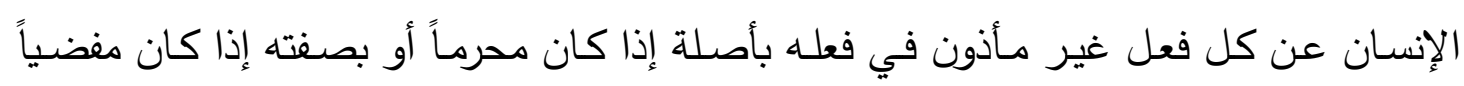

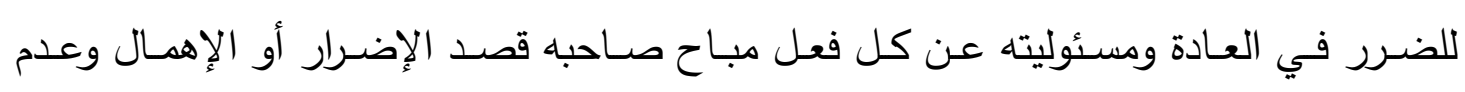
التبصر . n

(')د/ محمد فتح الله النشار - حق التعويض الدني بين الفقه والقضاء الإسلامي والقانون الددني ، طبعة دار

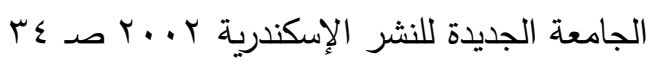

$$
\begin{aligned}
& \text { (')(المدثر - الآية حبr. }
\end{aligned}
$$

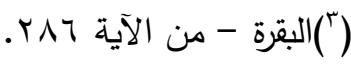

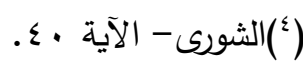

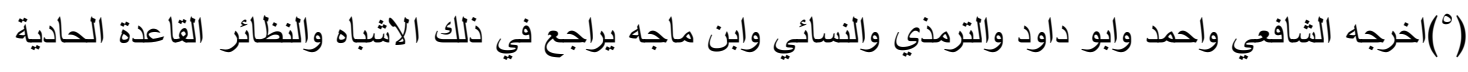

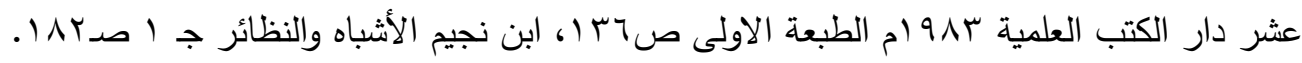

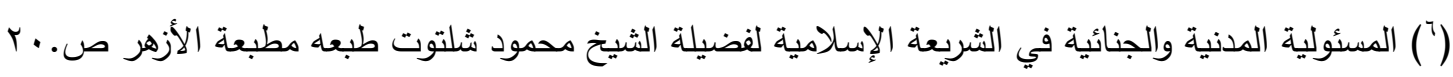


والثاني: تحول الضمان لكل ما يتأذى به المرو في جسمه ونفسه وحقوقه التي كفلها له

والفقهاء يعتبرون كل فعل يؤدي إلى إلحاق الأذى بالغير ضرراً غير أنه إذا لم يترتب

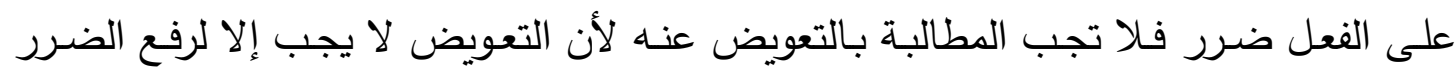

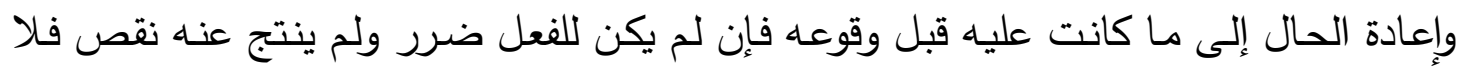
شيء على فاعله (r). والثريعة الإسـلامية تتضمن أصسلاً عاماً يقضي بأن كل عمل غير مشروع يلحق ضرراً بالغير

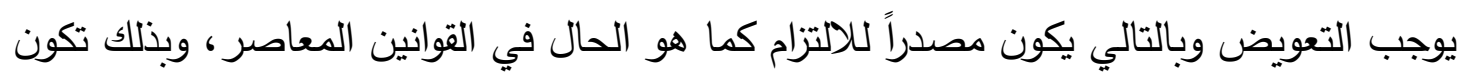
قد فتحت الباب أمام المسائلة وخاصة في المسئولية التقصيرية حيث إنها لم تثترط التمييز لإقرار

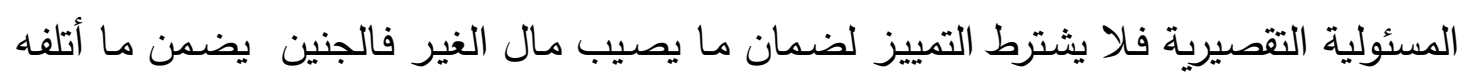

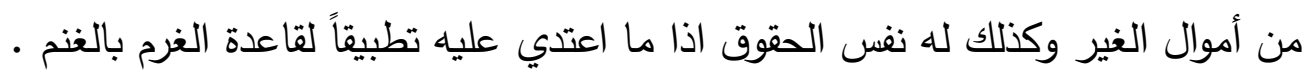

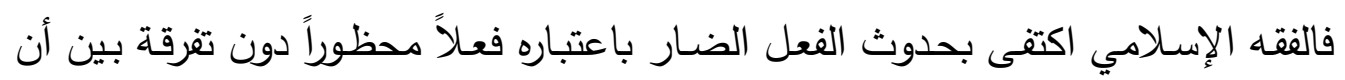

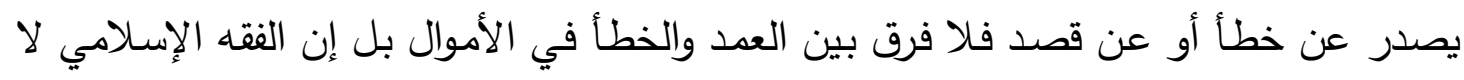

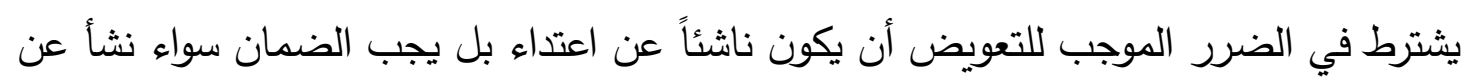

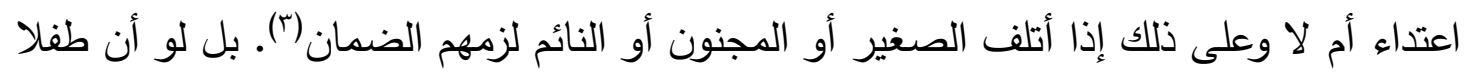

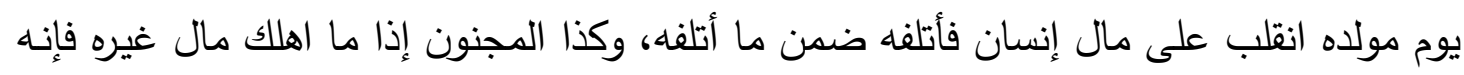

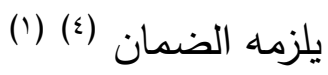

(')د/ مصطفى محمد الجمال القانون الددني في ثوبه الإسلامي مصادر الالتزام ط الأولى بدون تاريخ طبع الفتح

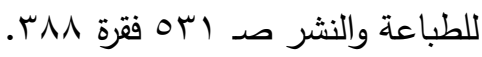

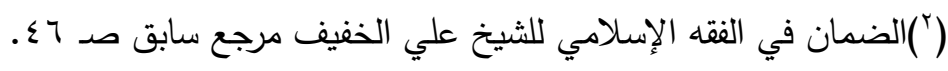

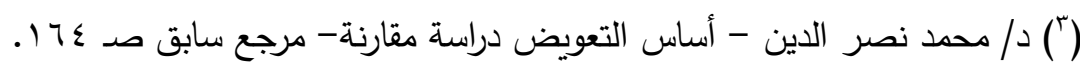

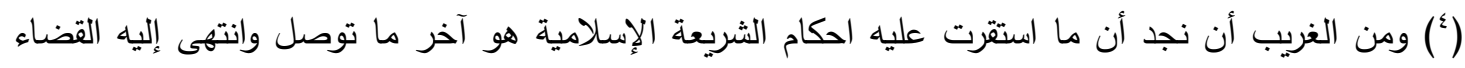

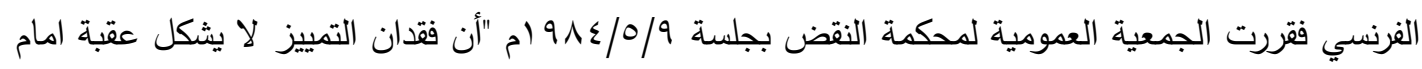

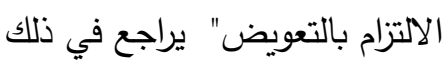

Viney $(G$ ) la réparation de dommages causes sous l' empire d'un état d' inconscience un transtet nécessaire de la responsabilité vers l' assurance, j.G.P. $1910,1-r 119$ 
وجاء في بدائع الصنائع "إإن سقطت فإن ثبت مكانها أخرى ينظر إن ثبتت صحيحة فلا

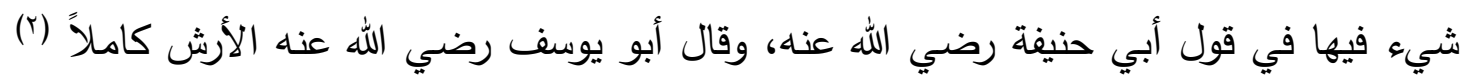

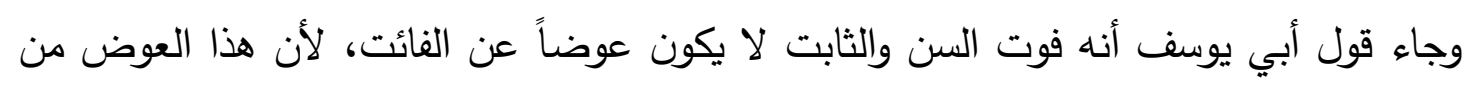

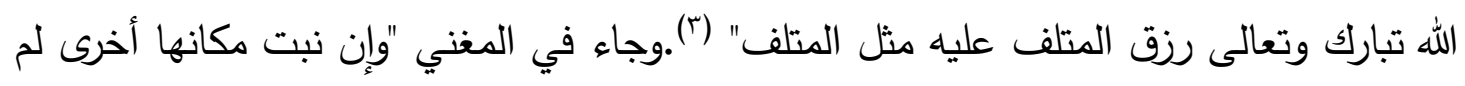
تجب ديتها كما لو نتف شعره فعاد مثله"(i). واعتقد أنه وإن كان هذا الرأي له حجيته إلا أنه ليس هناك ما يمنه لهاد أن أن يعوض الجنين جراء الآلام والأحزان التي اعترته فله الحق في التعويض عن الضرر المادي و الضرر المعنوي .

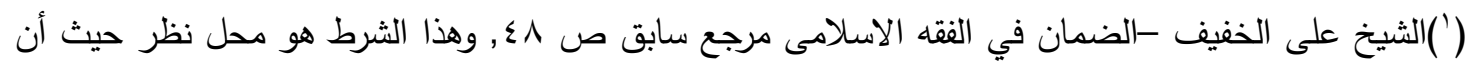

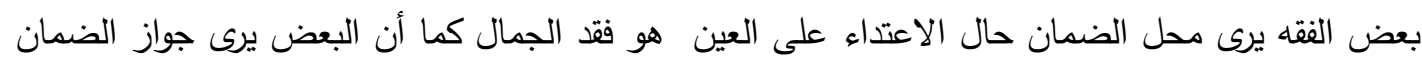

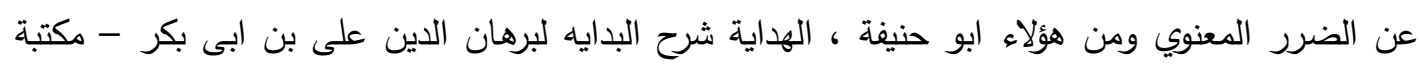

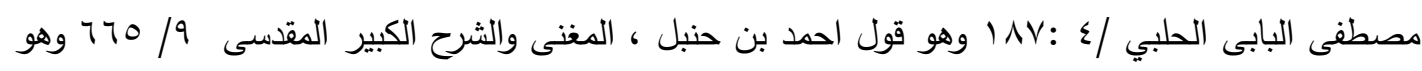

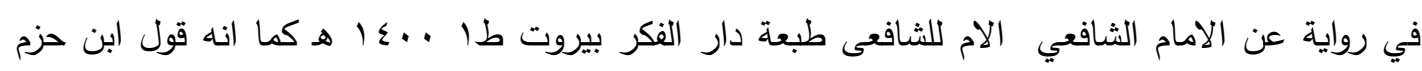

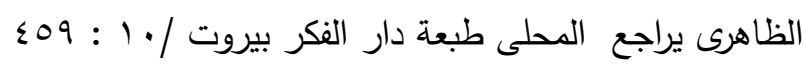

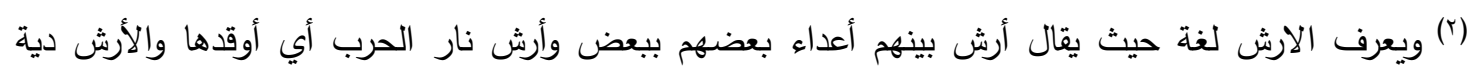

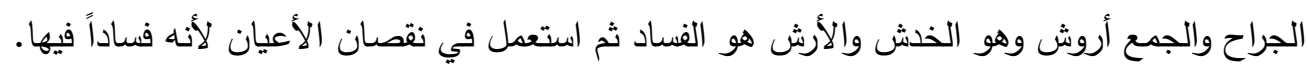

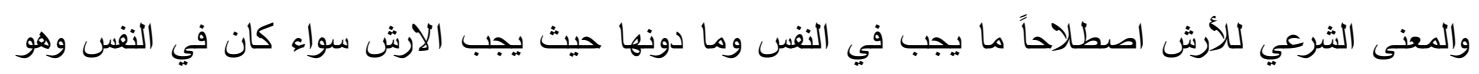

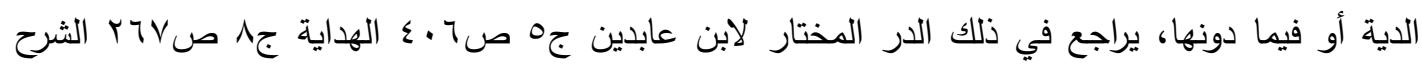

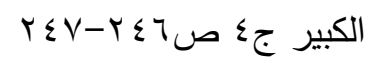

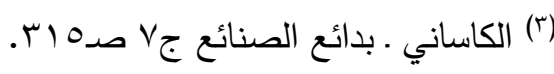

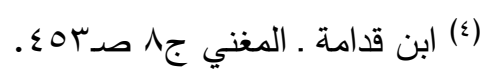




\title{
الإلب الثاني
}

\section{شروط استمقاق المنين للتعويض}

ذهب الفقهاء الى امكانية تملك الجنين للحقوق المالية خلال مدة الحمل غير أن هذه

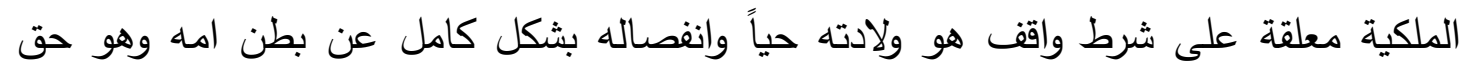
مكتمل يسمى بالحق الشرطي وهو حق مكتمل الاركان ومن ثم فان للجنين ان يتملك الاموال وهو في بطن امه غير ان هذه الملكية لا تتاكد الا منذ ولادته حيا وهذه الملكية ليست على سبيل

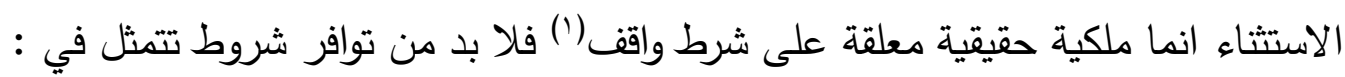

الثرط الأول: يجب أن يكون ضرر الجنين ضرراً محقًا (؟)

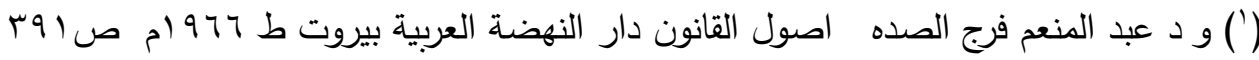

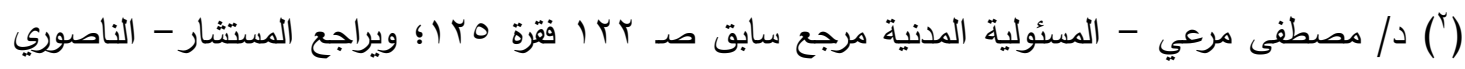
والدكتور/الثواربي مرجع سابق صـ lov إ؛ وفى شأن اشتراط تحقق الضرر حتى يمكن التعويض عنه يقارن في الفقه الفرنسي
\end{abstract}

Le Tourneau (PH.), Droit de la responsabilité et des contrats, D. ... ₹, No.1 1 ., p.rro; Mazeaud (H.J.) et Chabas (F.), Leçons de droit civil.. op. cit No.s।, p 17.

كما أنه لا خلاف بين فقهاء الثريعة الإسلامية على اشتراط تحقق الضرر حتى يمكن ضمانه والمقصود من

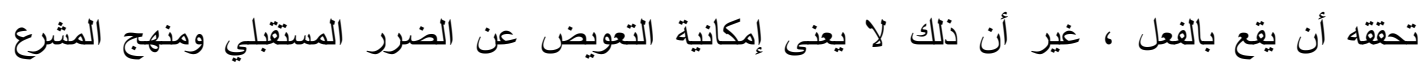

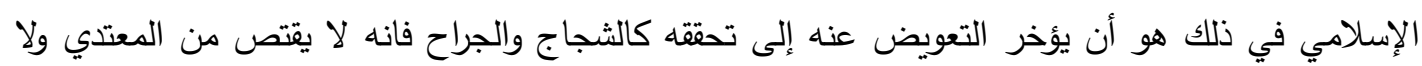

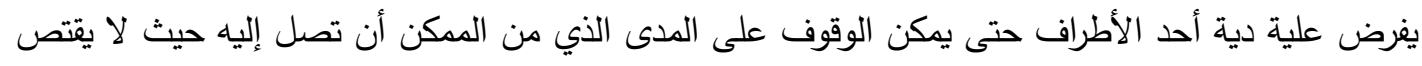

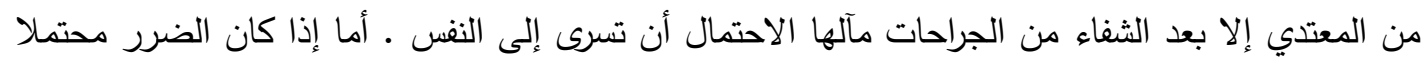

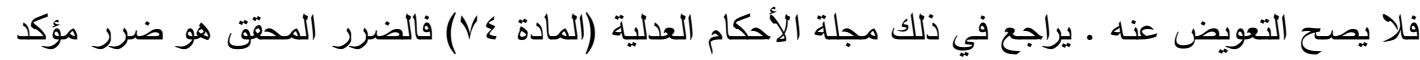

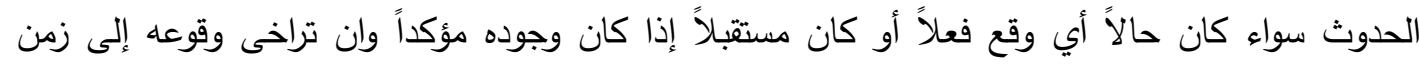

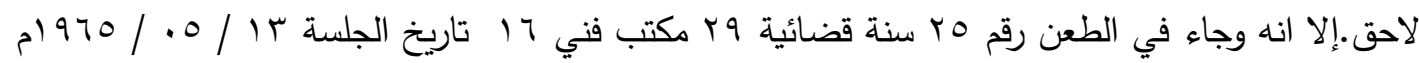
،لا يجوز التعويض عن الضرر المحتمل وهو الضرر الذي لم يقع ولا يوجد ما يؤكد وقوعه مستقبلاً.ويعتبر

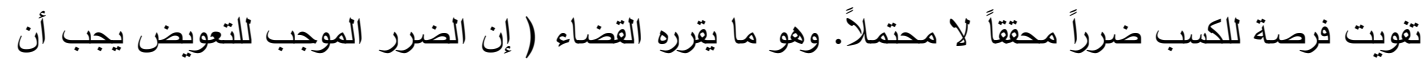

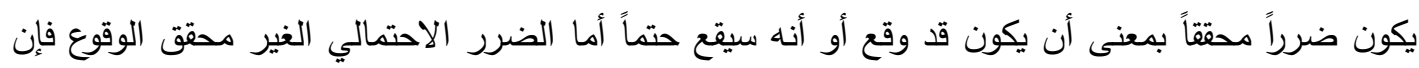
التعويض عنه لا يستحق إلا إذا وقع فعلاً ). 


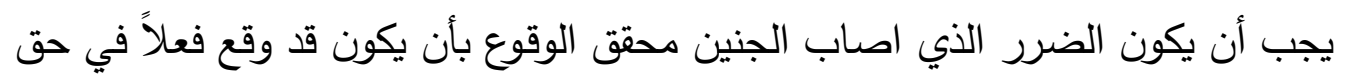

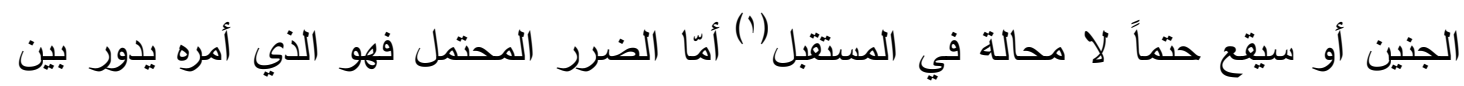

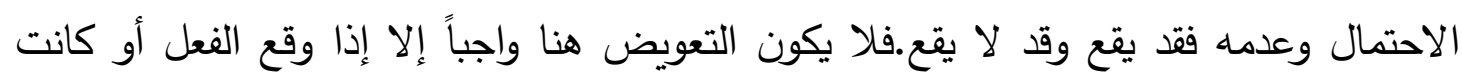

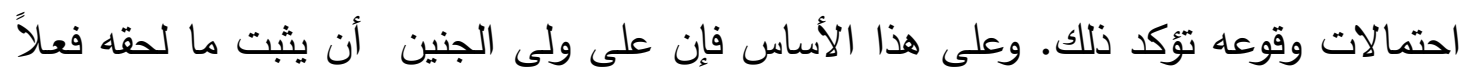

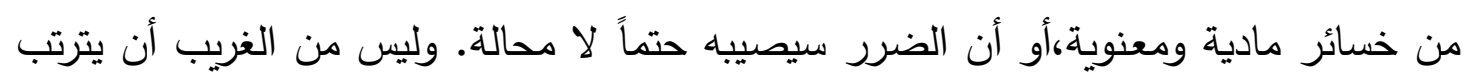

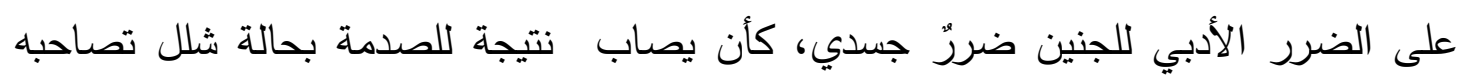

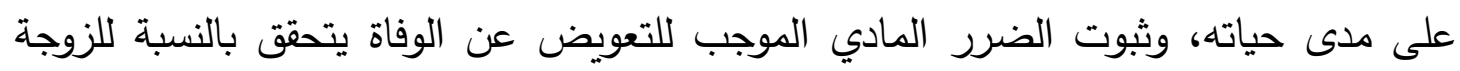

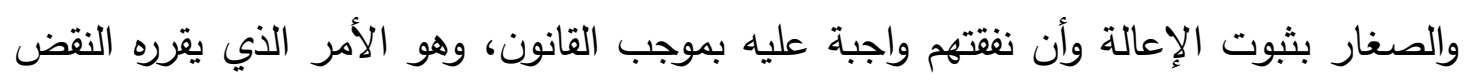

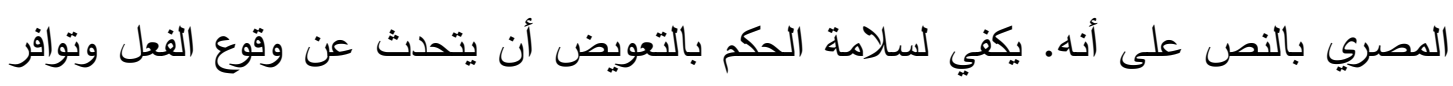
الضرر ...) فإذا لم يتحقق شرط وجوب النفقة يكون الحكم في مثل هذه الحالة معيبا بالقصور (r).

الثرط الثاني: أن يصيب الضرر حقاً أو مصلحة مشروعة للمضرور (") مشروعية الضرر شرط أولي لقيام المسئولية المدنية وإمكانية المطالبة بالتعويض لا

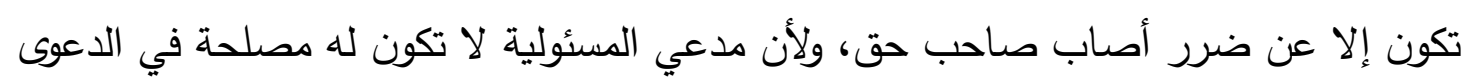

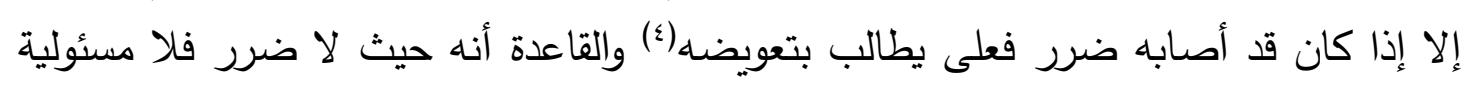

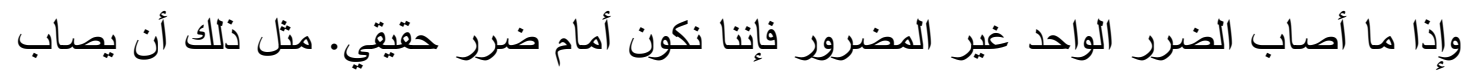

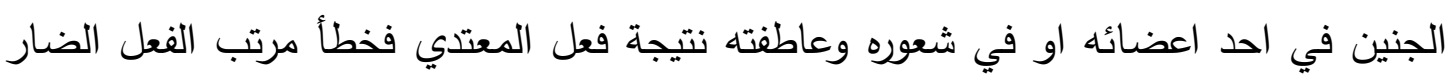

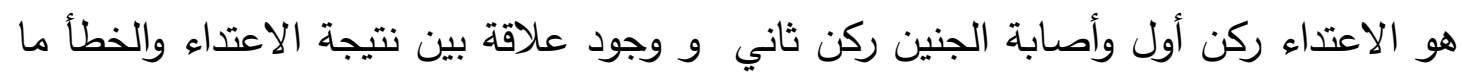

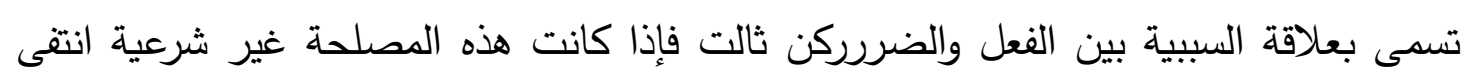

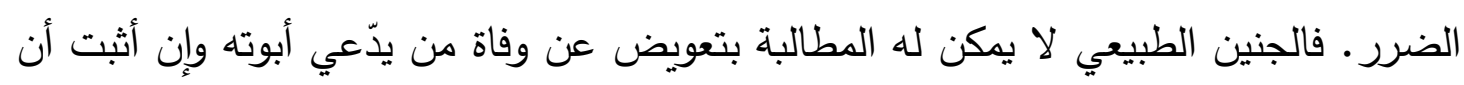

(') د/ محمد حسن عبد الرحمن - مصادر الالتزام دراسة مقارنة - طr، ـ ـ . r، دار النهضة العربية، القاهرة،

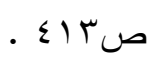

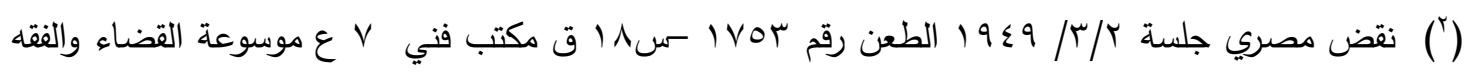

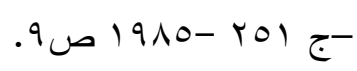

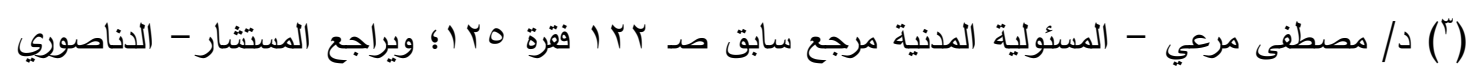

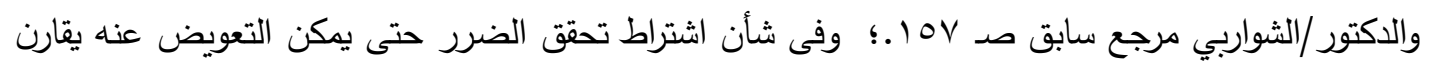
في الفقه الفرنسي Le Tourneau (PH.), Droit de la responsabilité et des contrats,op.cit No. I rq , p.rT (') Mazeaud (H.L.)Taité de la responsabilité civile, T.r, re éd., op.cit. No.roN. 
والده الغير شرعي كان يغدق عليه من ماله، ويعتبره ابنا له دون أن يسعى إلى إلحاقه بنسبه أمّا

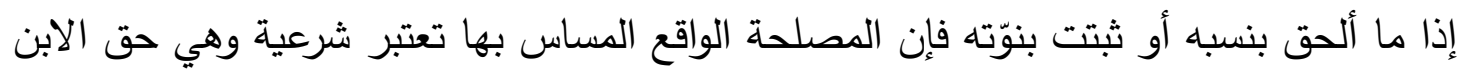
في النفقة. ولم يُعلم في القضاء العربي مثل هذا الحكم الذي يسمح بتعويض الأضرار الأدبية

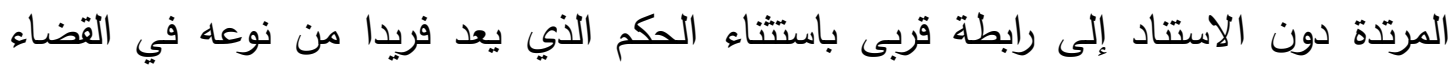

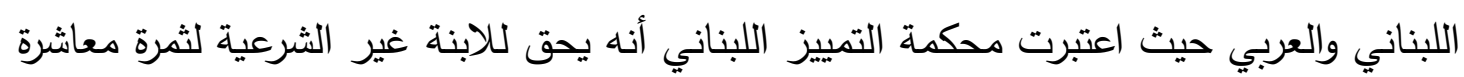
خارج نطاق الزواج أن تطالب والدها غير الشرعي بالتعويض عن الضرر الذي لحقها بتسببه بوجودها في هذه الدنيا على هذا النحو (') الثرط الثالث: علاقة السببية بين الفعل الضار الذي صدر من الفاعل وبين الضرر الذي

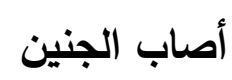

يشترط في الضرر الذي يصيب الجنين حتى يمكن التعويض عنه أن يكون نتيجة

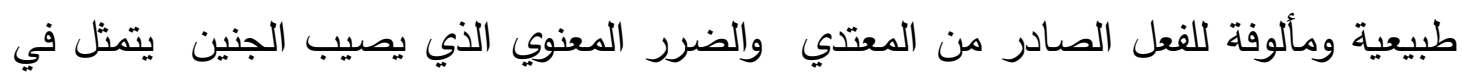

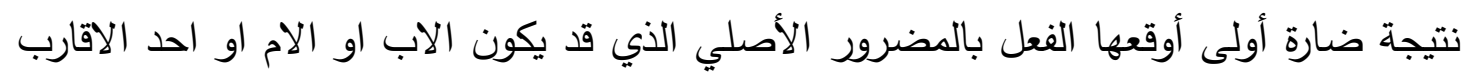

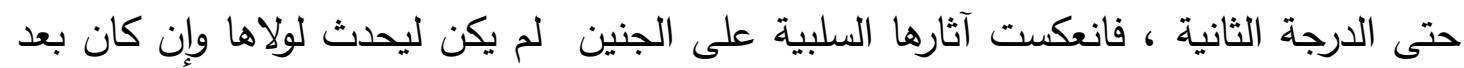

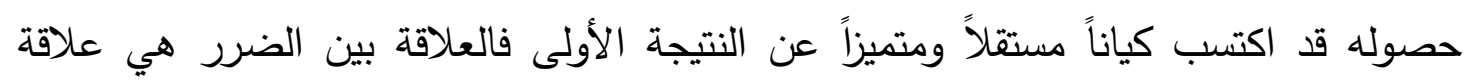

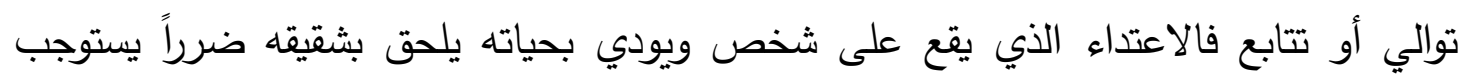

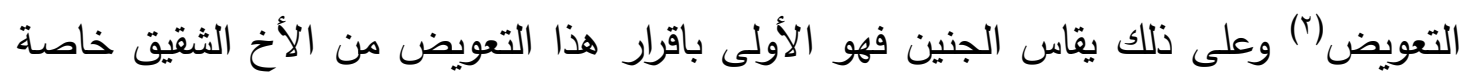
في مجال الأضرار الأدبية

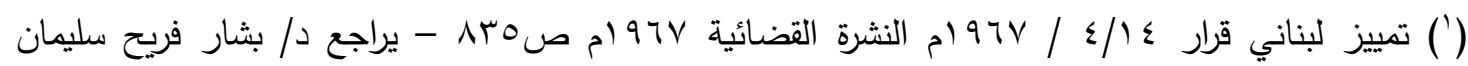
دراغمه - التعويض عن الضرر المعنوي في المسئولية التقصيرية وفقا لأحكام القانون المدني الأردني -رسالة

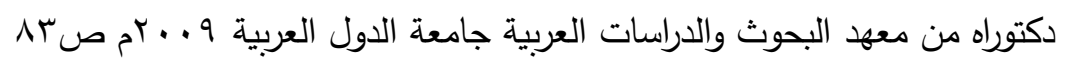

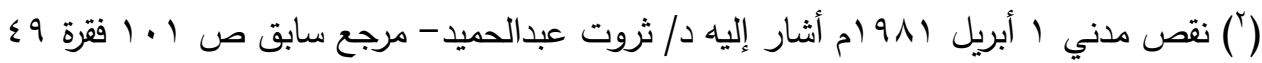

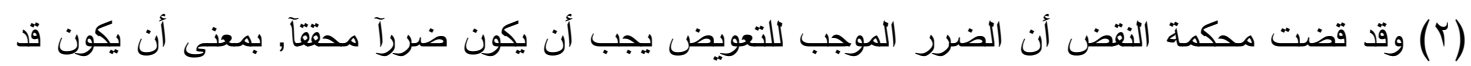

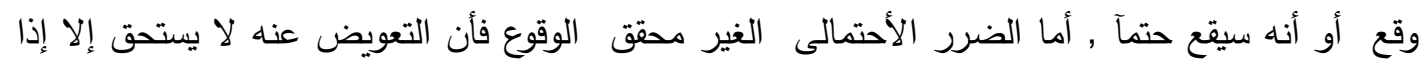

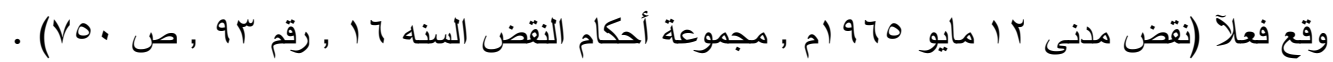
(ץ) د/ عبد الرازق السنهورى :الوجيز فى شرح القانون المدنى , الجزء الأول , نظرية الألتزام بوجه عام , الطبعة

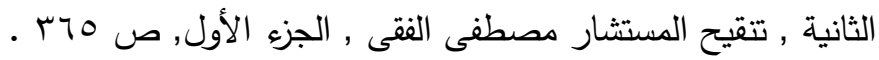


تعويض الأجنة عن الأضر ار المدنية دراسة مقارنة بين القانون المدني المصري ، والشريعة الإسلامية

وقد يكون الضرر محتملا فلا هو قد تحقق فعلاً, ولا هو محقق الوقوع في المستقبل,

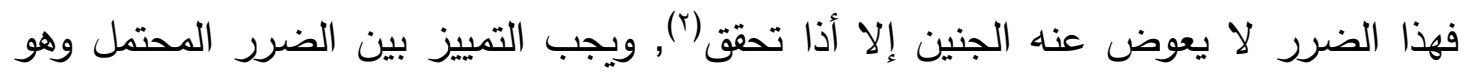
الذي لا يعوض عنه الجنين إلا إذا تحقق فعلاً وبين تفويت الفرصة (perte d"une chance)

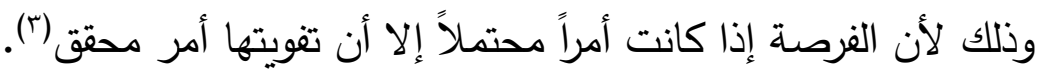




\section{المبمث الثالث}

\section{أهاية اكتساب الجنين للتعويض}

وقد قسمت المبحث هذا الى ثلاث لمطالب :

المطلب الاول : الإقرار بالثخصية القانونية للجنين المطلب الثاني : موقف الفقه الإسلامي من صلاحية الجنين لاكتساب الحقوق المطلب الثالث : موقف الفقه القانوني من حق الجنين في التعويض

\section{المباب الاول}

\section{الإقرار بالشخصية القانونية للجنين}

من سمات الثخصية القانونية اتصافها بالأهلية ولأهلية مشتقة من كلمة أهل، وتعنى الاستحقاق

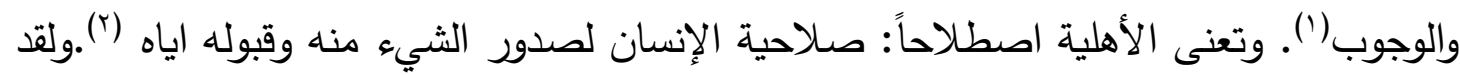
اعتبر فقهاء الثريعة أن للجنين أهلية وجوب ناقصة ويعبرون عنها بالذمة المالية (أ. ومعنى أن أهلية الجنين ناقصة أي تتبت له بعض الحقوق دون البعض ولا تجب عليه الواجبات

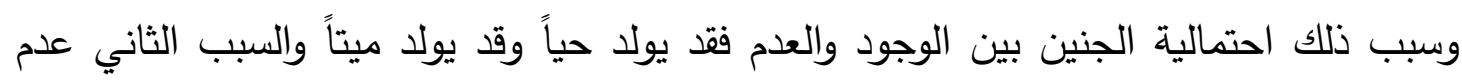
استقلاله عن امه فيعتبر جزء منها (')

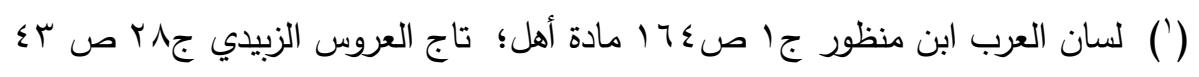

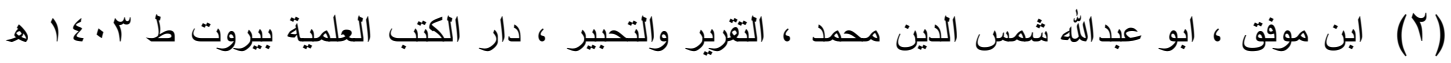

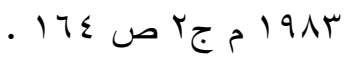

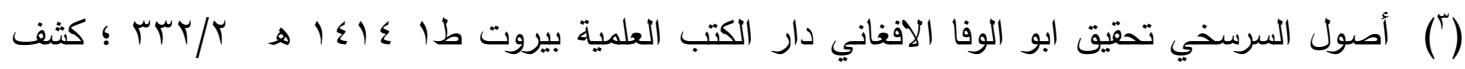

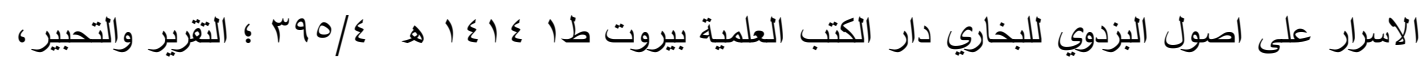

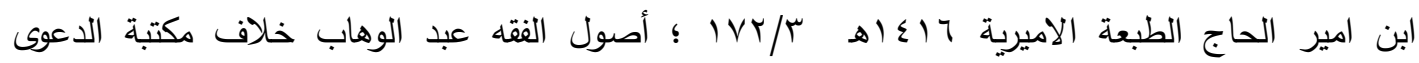

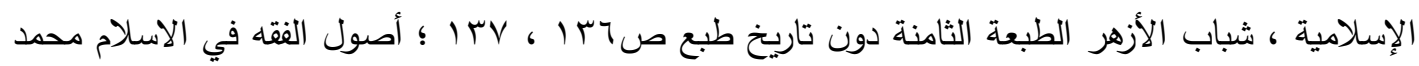

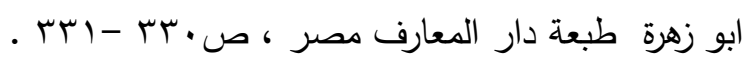


والأهلية نوعان أهلية وجوب وأهلية اداء الاولى: تعني صلاحية الانسان لوجوب الحقوق

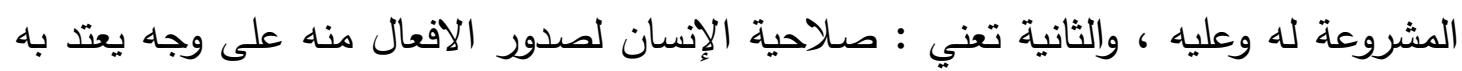

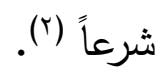

واختلف الفقهاء حول ثبوت الثخصية القانونية للجنين ما بين معترف ومنكر ، حسب النظر إلى كأى الجنين ككيان مستقل أو منفصل عن أمه، فتكون له شخصية قانونية مستقلة عنها، أو باعتباره

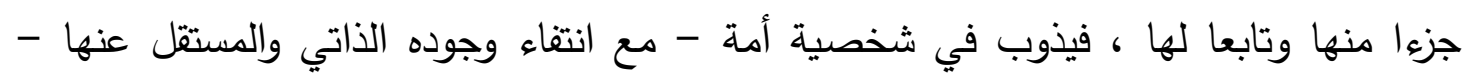

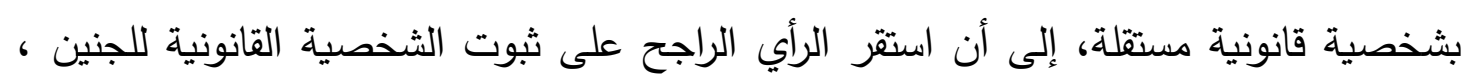

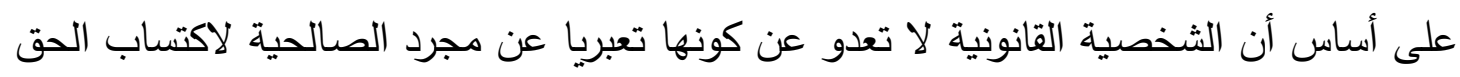

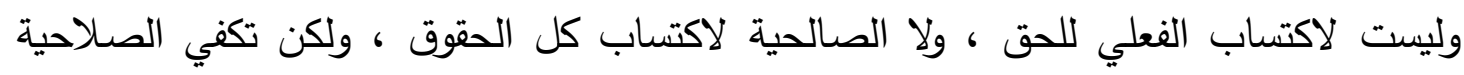

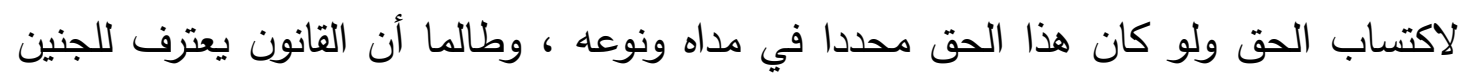

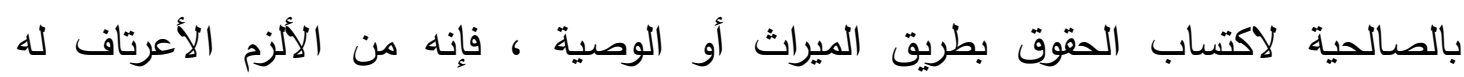

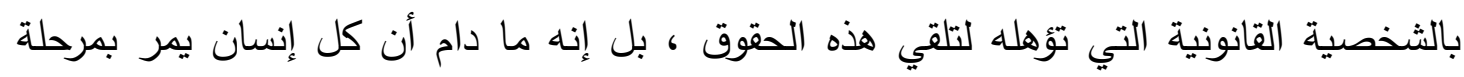

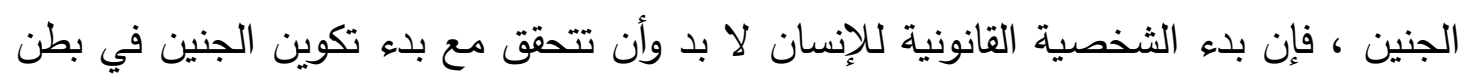

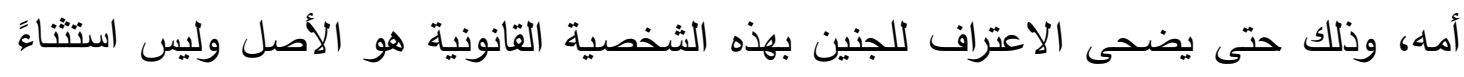

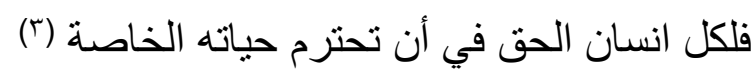
بما يكفل له الحماية الفعالة تجاه الكافة بما فيهم والديه ، لأن افتراض الثخصية الكاملة تثبت له

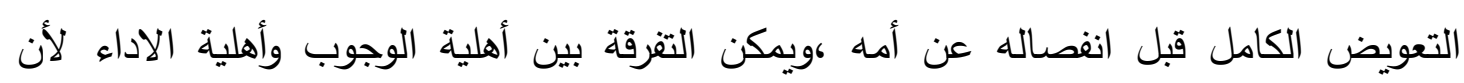

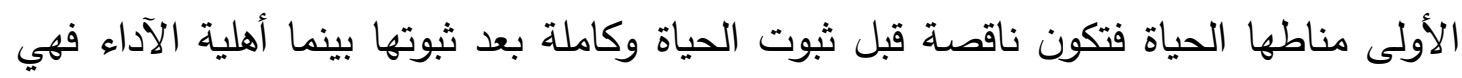

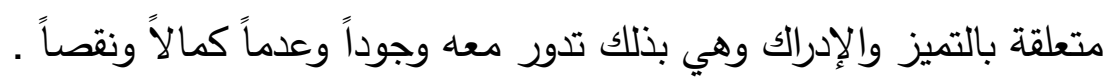

(') (') أصول الفقه لأبي زهرة ص آب (1)

(') د السنهوري الوسيط في شرح القانون المدني الجديد ، ج) مصادر الالتزام ، منشورات الحلبي الحقوقية

$$
\text { بيروت ، 1991 م فقرة }
$$

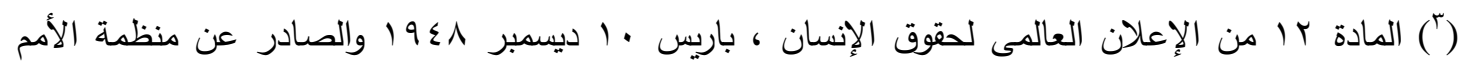

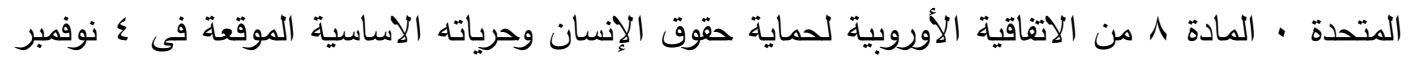

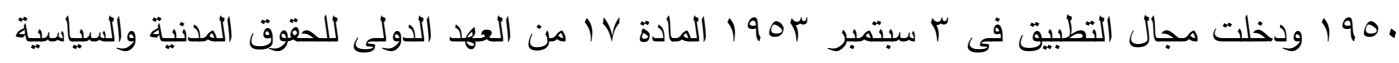

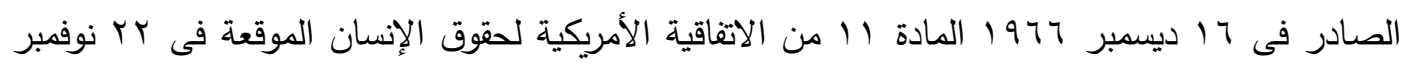

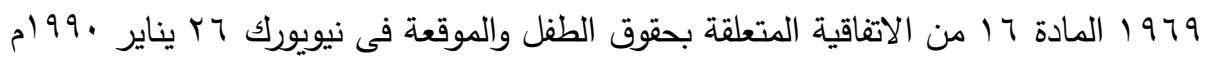




\section{الامطب الثانبي \\ موقف الفقه الإسلامي من صلامية الهنين لاكتساب المقوق}

يرى جمهور الفقهاء من المالكية والحنفية وبعض من فقهاء الثافعية أن الجنين ينعم بالحماية الثرعية منذ لحظة نثأته وتكوينه داخل الرحم وتستمر تلك الحماية طوال فترة وجوده الخداه داخل الرحم على أساس أنه كأن معد للحياة فتتبت له حرمة الحي قياساً عليه ('). عن أبي هريرة رضي الله عنه أنه قال: قضى رسول الله - صلى الله عليه وسلم - في

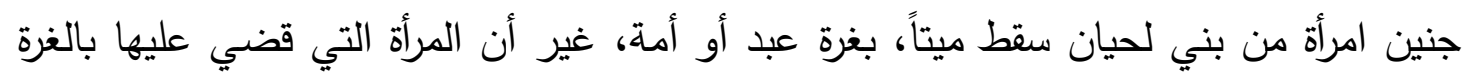

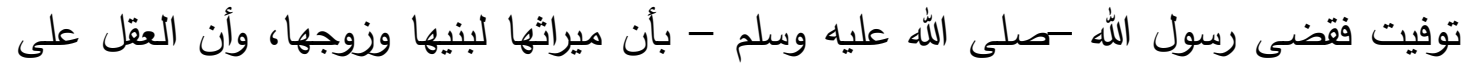
عصبتها فصح أن رسول الله -صلى الله عليه وسلم -قضى بالميراث لغير من قضى عليه

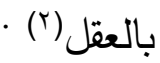

وجزاء الجناية على الجنين في الفقه الاسلامي مضمون بالمال ـ فاذا اتلف الجنين بسبب

الجناية علي امه يكون مضموناً بالمال فتكون الغرة ().

أما اذا انفصل الجنين ثم مات متأثراً بالجناية فتكون الدية ـ والمالكية يوجبون القصاص

من الجاني اذا انفصل الجنين حياً ثم مات من جنايته عمداً (؛).

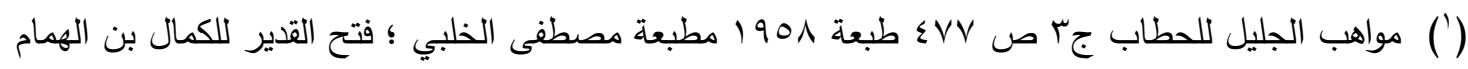

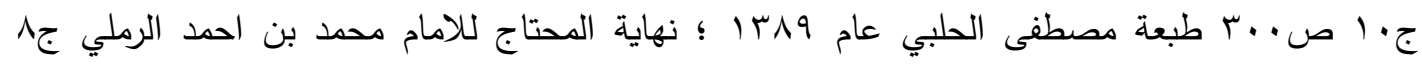

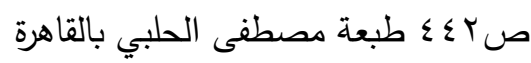

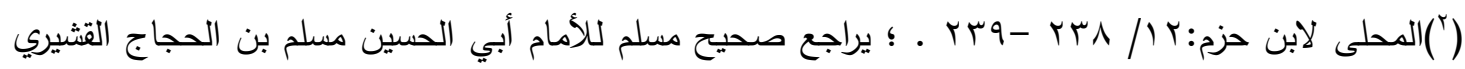

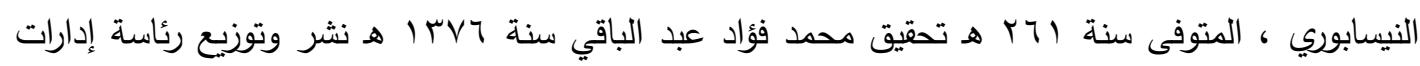

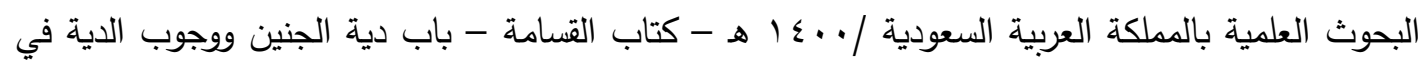

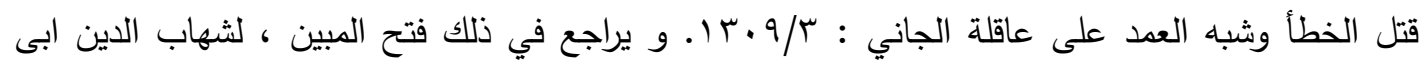

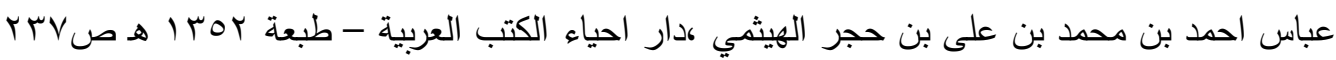

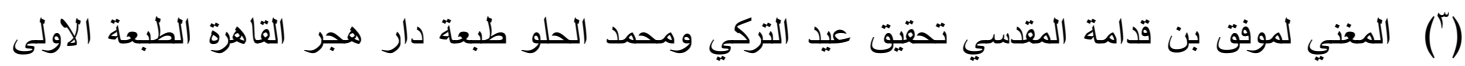
$09 / 1$ r

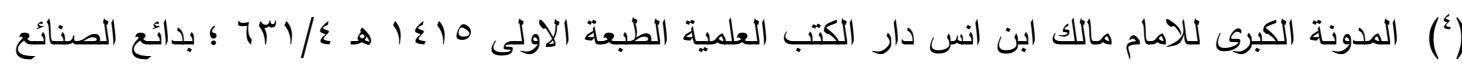

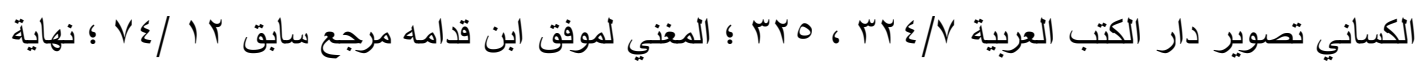


وهذا لايتعارض مع اتجاه الفقه الإسلامي الذي يرى أنه لا يكون للجنين أهلية وجوب كاملة بل

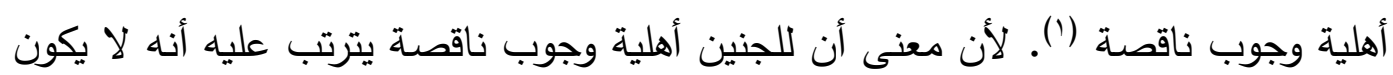

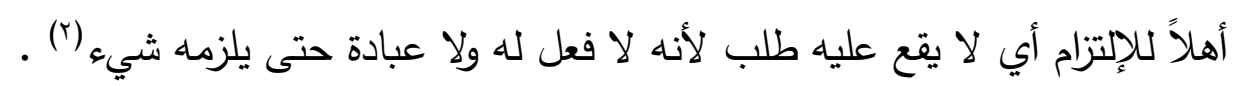

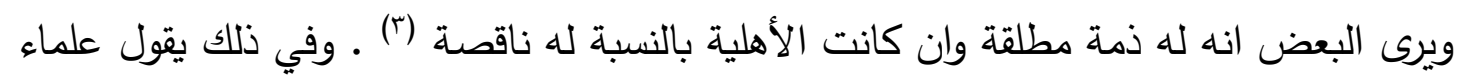

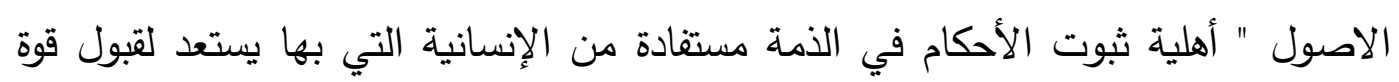

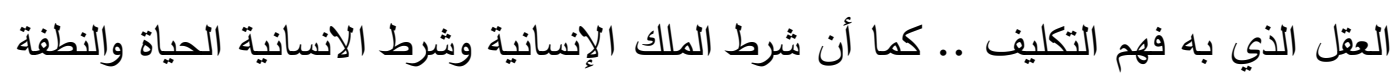

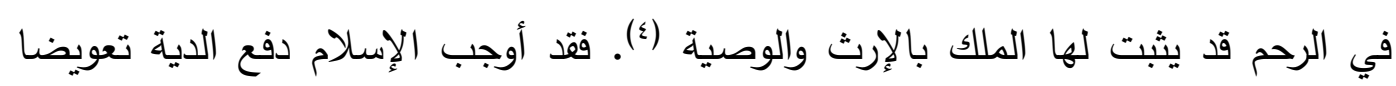

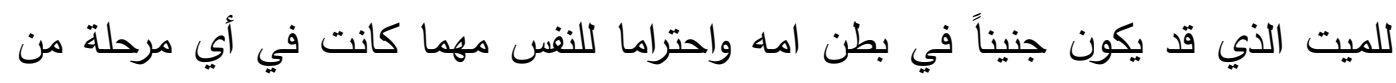

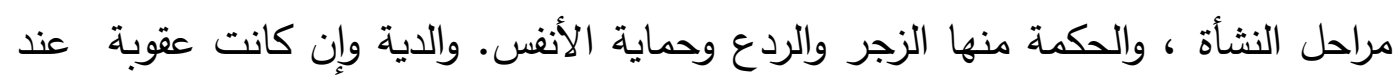

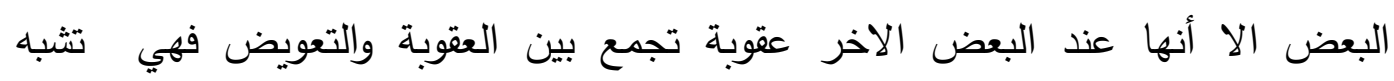

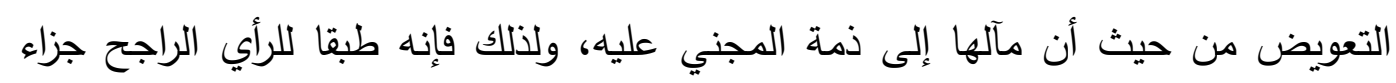
يجمع بين العقوبة والتعويض معا.

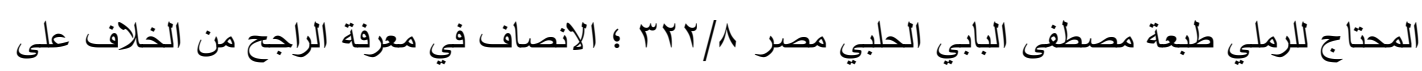

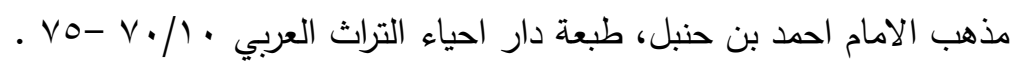

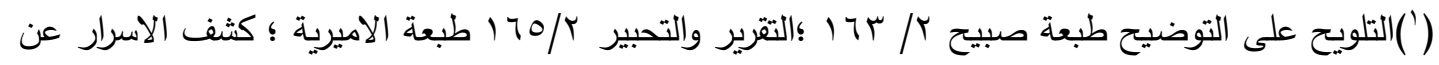

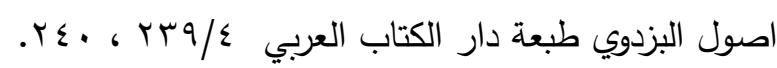

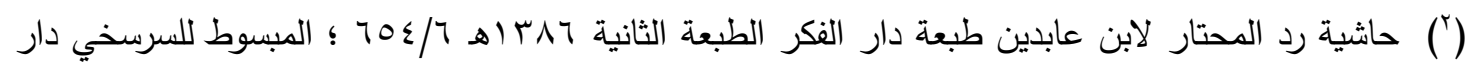

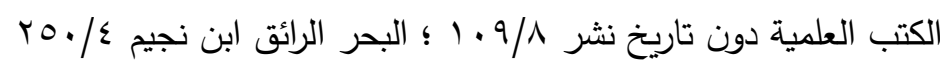

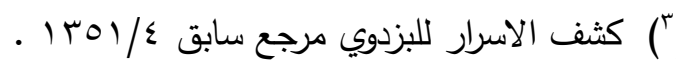

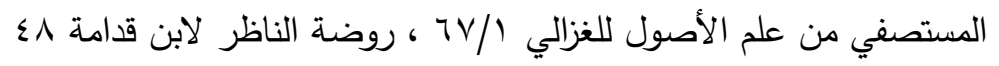




\section{المطالب الثالث}

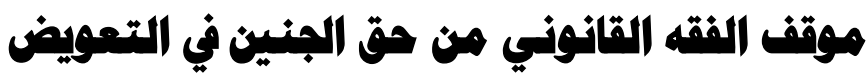

يقسم الفقه القانوني الأهلية إلى نوعين :اولاً. أهلية الوجوب أو تمتع ، وثانياً: أهلية الأداء أو

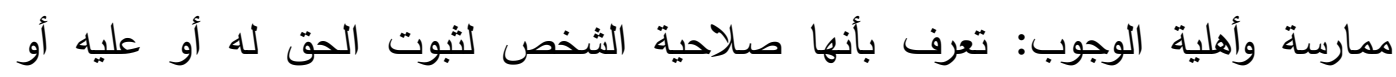

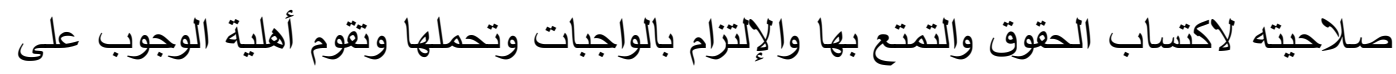
عنصرين هما: أ- صلاحية الثخص أو قدرته على التمتع بالحقوق أي صلاحيته لأن يكون صاحب حق كصاحب حق الملكية.

ب- صلاحية الثخص أو قدرته على الالتزام بالواجبات أي صلاحيته لأن يكون مكلفاً بالتزام.

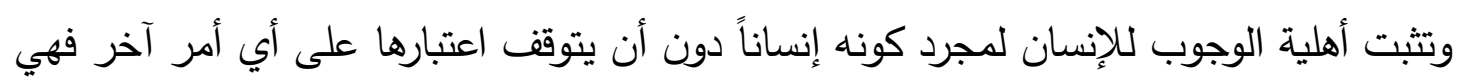

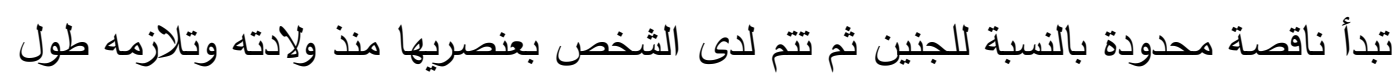

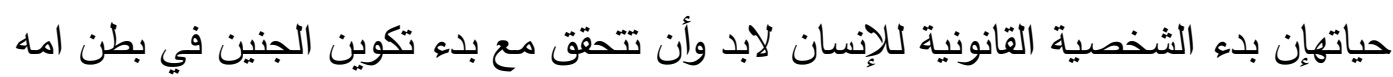
وذلك حتى يضحى الاعتراف للجنين بالثخصية القانونية هو الأصل لا الاستثاء ( (.)وقياساً

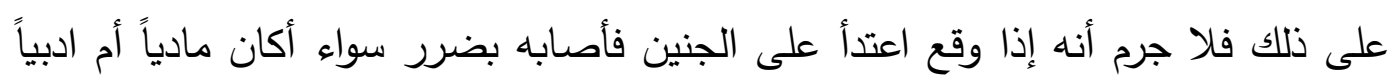

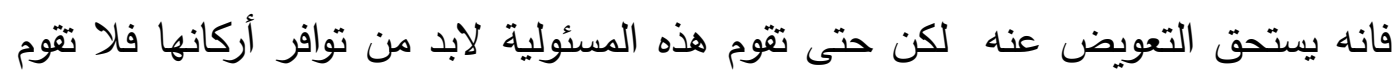

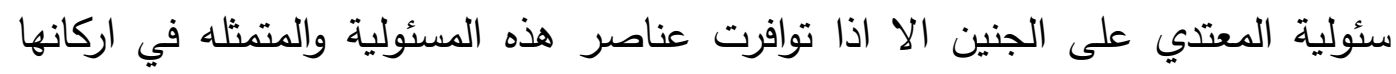

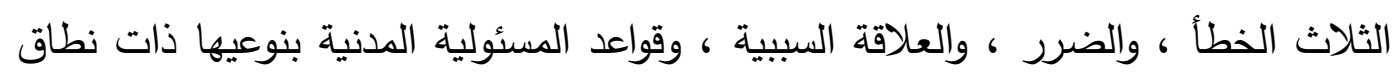

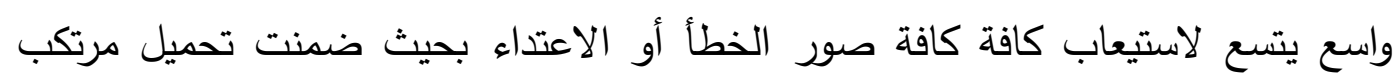
الفعل المعتدي تضمينه تلك الأضرار الواقعة على الجنين اياً كانت شخصية المعتدي واياً

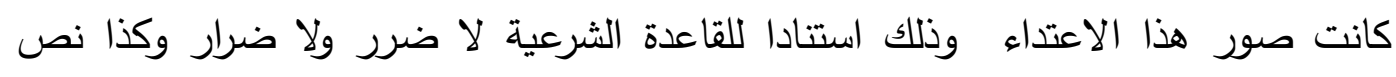

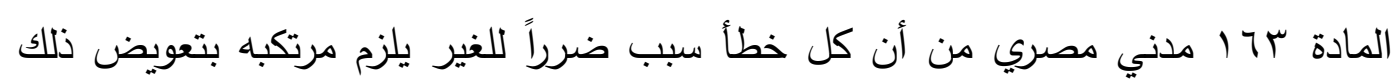

الغير

والحقيقةأن الفقه إنقسم إلى عدة اتجاهات حول أساس صلاحية الجنين لاكتساب الحقوق: الاتجاه الأول:عدم صلاحية الجنين لاكتساب الحقوق و انقسم هذا الاتجاه الدعدة آراء :

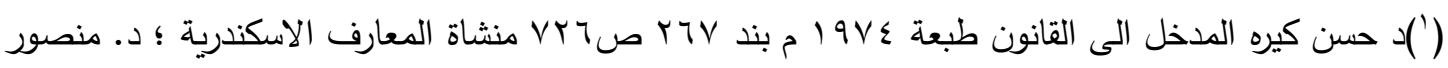

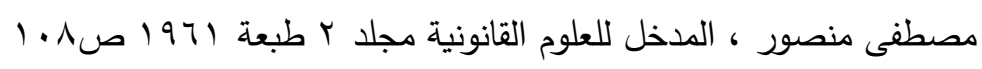


الرأي الأول: يرى أن الأصل عدم ثبوت الثخصية القانونية للانسان إلا بتمام ولادته حيا.حيث يرى أن الجنين

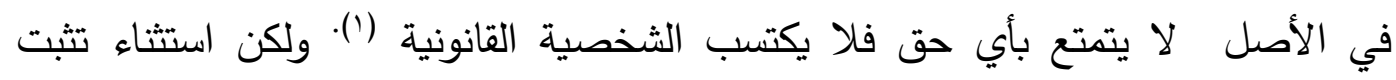

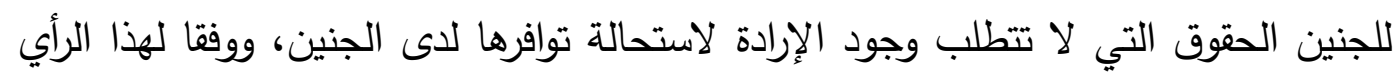
تثبت الثخصية القانونية منذ وجود الحمل وتستمر معه بعد تحقق الولادة حيا.

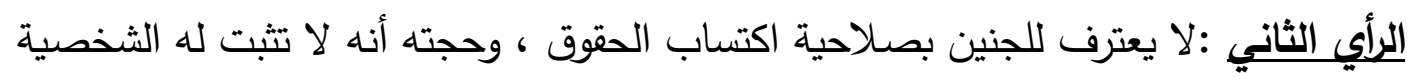

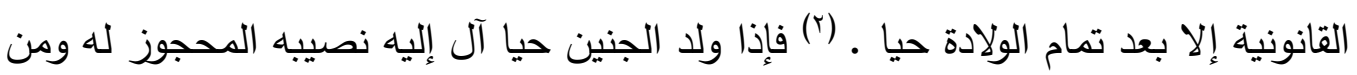

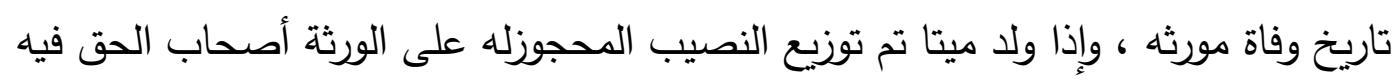

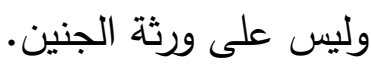

الإنجاه الثاني : يرى ان الجنين يتمتع ببعض الحقوق مما يعني الاعتراف له بالثخصية

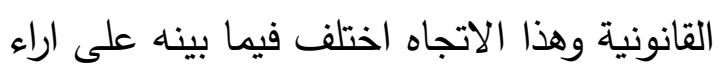

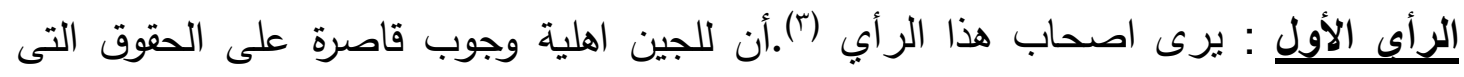

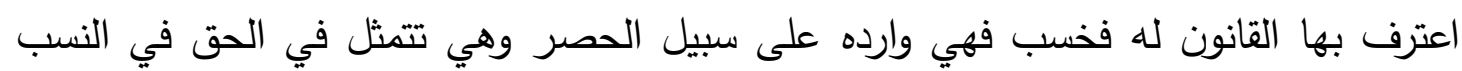

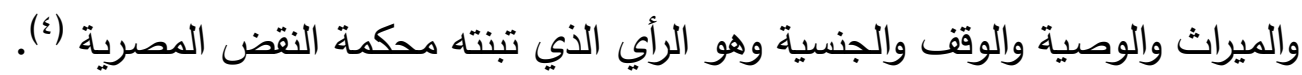
الرأى الثاني : يثبت للجنين من الحقوق ما لا يتوقف ثبوته على قبول منه أما الحقوق التى يتوقف ثبوتها على قبول ممن تمنح له فلا تكون للجنين مثل الهبة وغيرها (0).

(') د. نعمان جمعه دروس في نظرية الحق ط 1970 دون ذكر دار نشر ص109 ، د محمد حسام لطفي ،

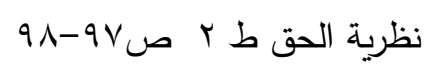

(') ويستثهد هذا الرأي بموقف المشرع من حقوق الحمل المستكن والتي تعتبر من قبيل الحماية القانونية لحق

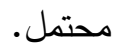

$$
\begin{aligned}
& \text { (") د عبد الدنعم البدراوي مرجع سابق ص rعه }
\end{aligned}
$$

(4) نقض مدني 1990/T/VT المستحدث من المبادئ التى اقرتها الدوائر المدنية بمحكمة النقض المكتب الفني ir.

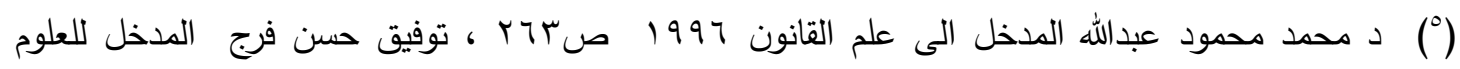

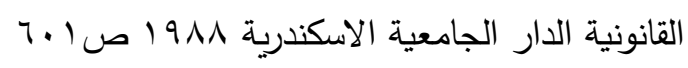


اللرأي الثالث : يراى أن الجنين صلاحية اكتساب اي حق ما دام هذا الحق نافعاً له نفعاً محضاً

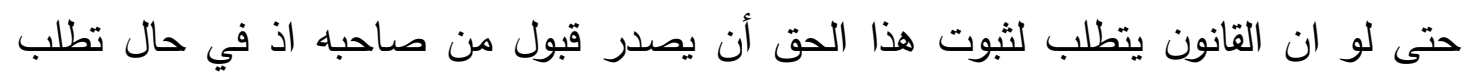
القانون منه هذا القبول فإن الوصي يقبل نيابة عن الجنين ('). الاتجاه الثالث : إن للجنين شخصية قانونية منذ وقت الحمل حيث ان شخصية الجنين تبدأ من

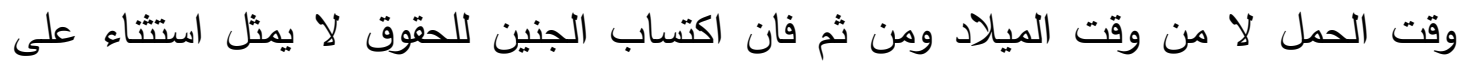

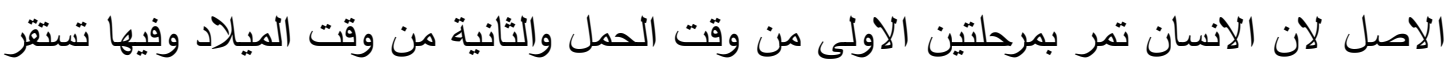

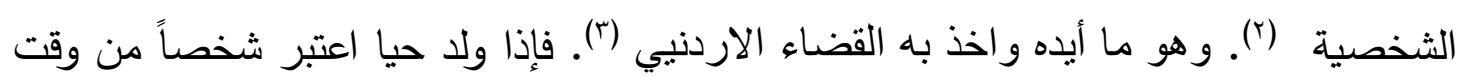

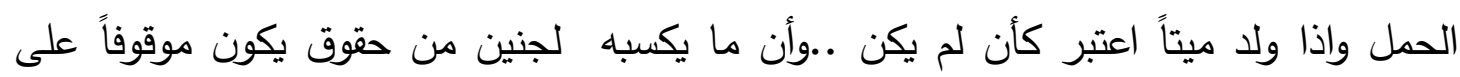

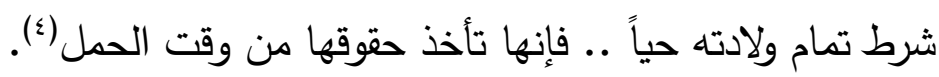

(') د حسام الاهواني مرجع سابق صَه ، د رمضان ابو السعود الوسيط في شرح القانون المدني الدذخل

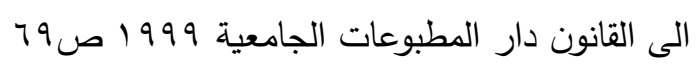

(") أمي القضية التى تتلخص وقائع الدعوى في ان احد الاشخاص توفى في حادث سير وكانت امرأة هذا

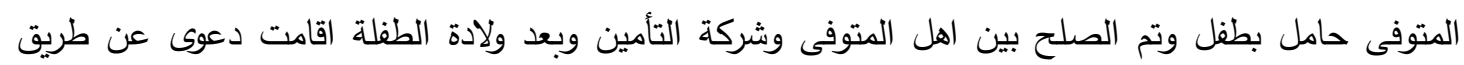

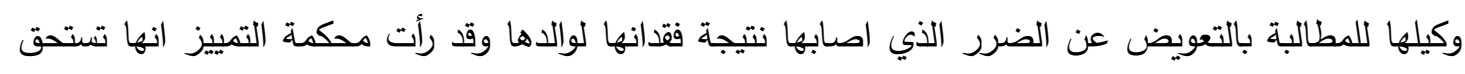

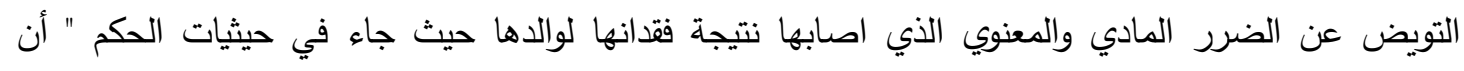

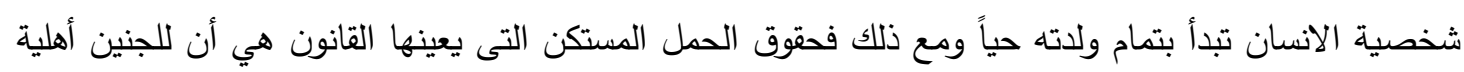
وجوب قاصرة على صلاحيته لكسب الحقوق النافعة له نفعا محضاً

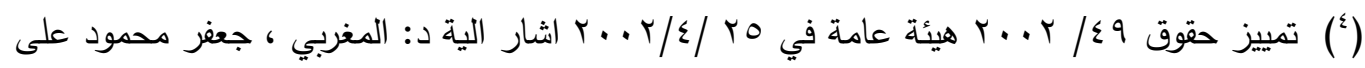

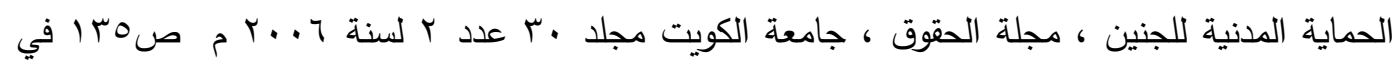

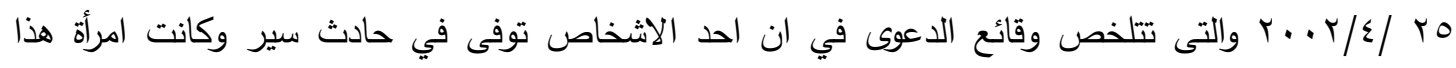

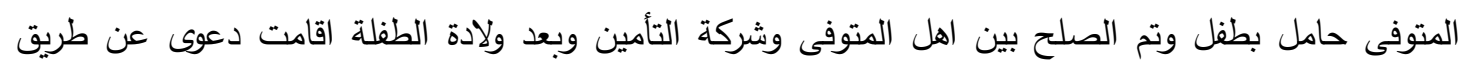

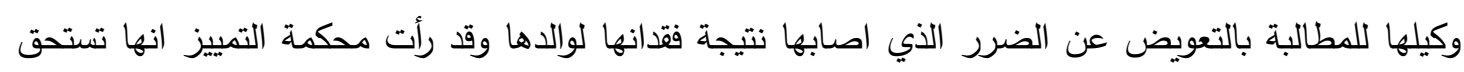

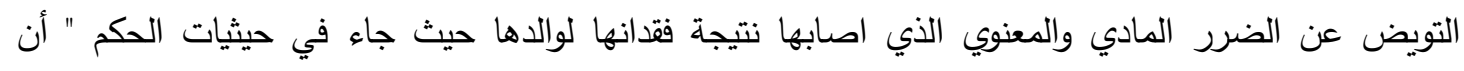

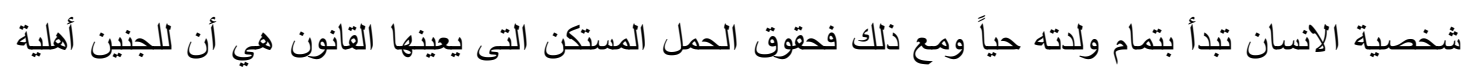

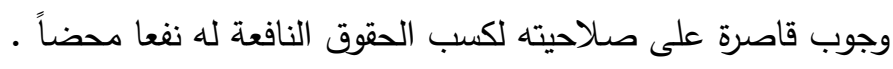




\section{المبحث الرابع}

\section{هوقف القضشاء من تعميض الجنين}

تضاربت اتجهات القضاء في شأن اقرار التعويض للجنين بين احكام تؤيد واخرى ترفض الإقرار

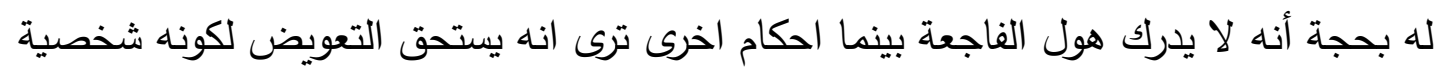

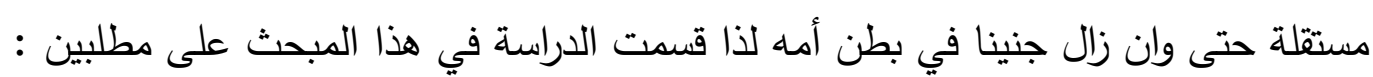

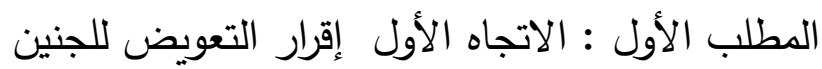
المطلب الثاني : الاتجاه الثاني رفض الورل القرار التعويض للجنين

\section{الإطباب الأول \\ الاتجهاه الأول إقرار التعميض لابنين}

تبنة محكمة النقض المصرية هذا الاتجاه مقررة أن قضاء الحكم المطعون فيه بالتعويض المادى الماء للمطعون ضده الأول عن فقده طفله الحمل المستكن الذى كان جنيناً في أحشاء والدته المتوفاة

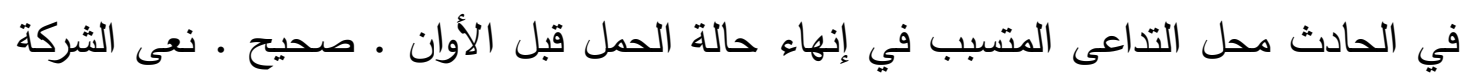

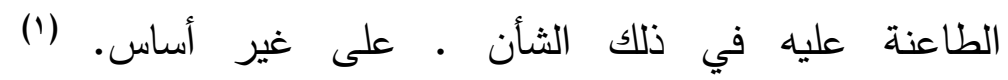

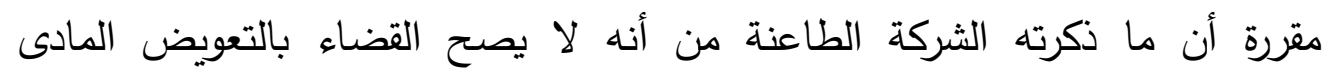

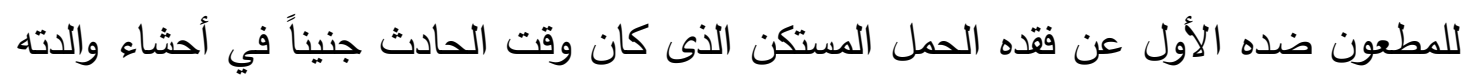

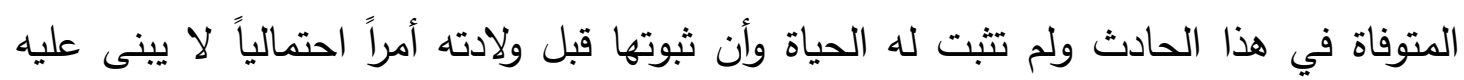

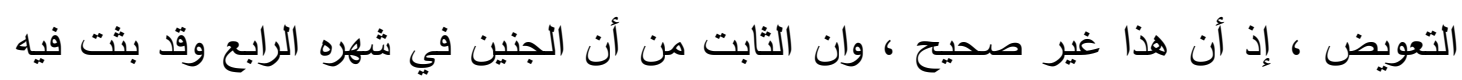

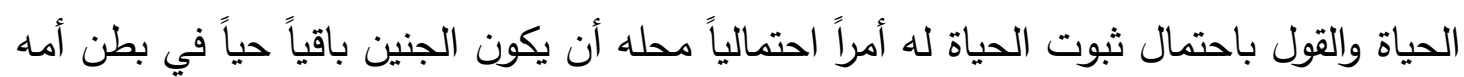

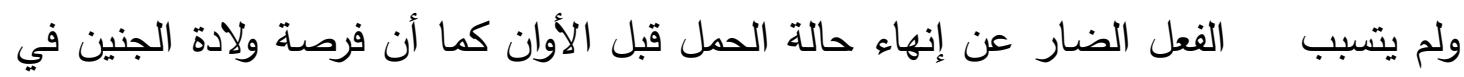

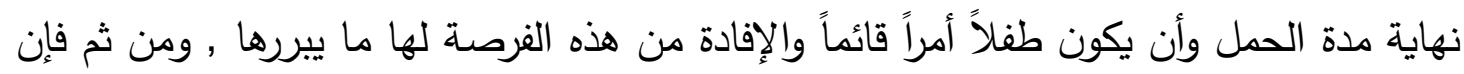

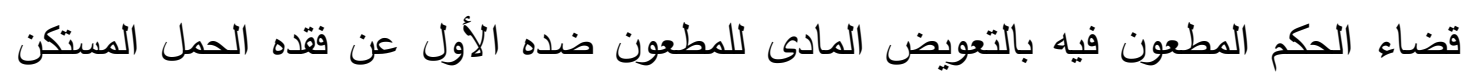

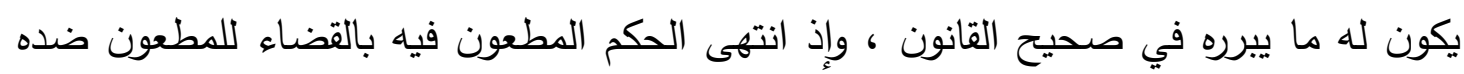

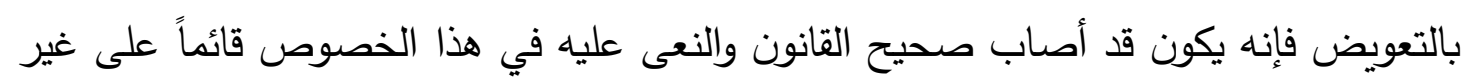


أساس. حيث قررت محكمة الاستئناف اثناء نظر الاعوة أن التزام محكمة الموضوع عن تقدير عناصر التعويض بإدخال ما ضاع على الوالد المضرور من إنهاء حالة حمل زوجته المتوفاة قبل الأوان بسبب خطأ المسئول والآثار المترتبة على ذلك ـ ـعلة ذلك ـ التعجيل بإنهاء الحمل

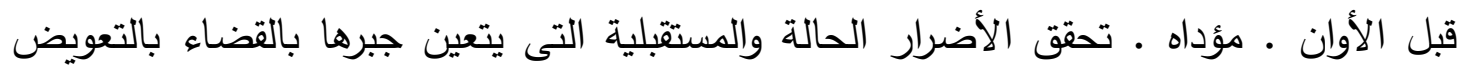
للوالد أو الوالدة عن فقدان هذا الحمل قبل ولادته سواء كان تعويضاً مادياً أو أدبياً . أثره ـ التزام المحكمة بتقدير التعويض الجابر للأضرار التى لحقت بالوالد نتيجة حرمانه من طفله (').

\section{تطبيقات قضائية لحق الجنين في التعويض}

يمكن القضاء للشخص المسئول عن الجنين الحق في رفع الدعوى للمطالبة بحق لله ولا يقوم هذا الحق الا إذا تحقق وقوع الضرر ، بمعنى أن يكون قد وقع بالفعل أو أن يثبت أنه سيقع حتماً في المستقبل لامحالة .

وذا استعرضنا نصت المادة بr T مدنى التى تصص على أنه يجوز الحكم بالتعويض للازواج والأقارب إلى الدرجة الثانية عما يصيبهم من الم من جراء موت المصاب نلاحظ أنه لم يشترط

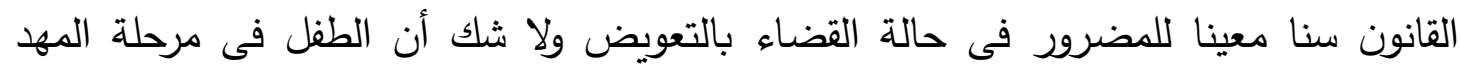
يصيبة الضرر المادي والأدبى من جراء وفاة والده أو والدتة أو اخوتة لارتباطة بمن حولة من هؤلاء ومن الصعوبة فصلة عنهم ويتحقق بفراقهم الألم والضرر • ولما كان القانون المدني يقرر

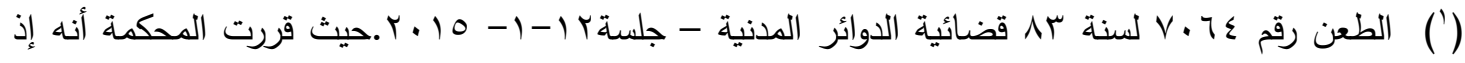
كان الثابت من الأوراق أن محكمة أول درجة قد عرضت في مدونات حكمها للتعويض عن الضرر المادى لماتئ المطالب به ورفضت القضاء به ، وتضمنت أسباب استئناف المضرورين النعى على حكم أول درجة برفضه عنه النه

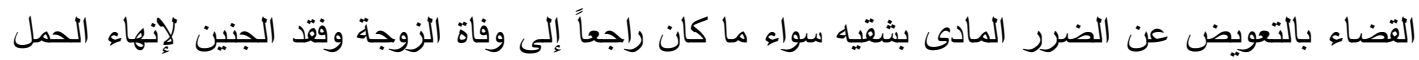

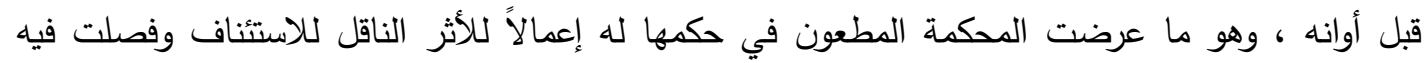
وقضى للمطعون ضده بالتعويض عن فوات الفرصة على سند من استحقاقه لهذا النوع من التعويض فإنه فئه

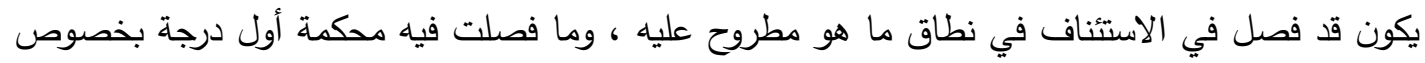

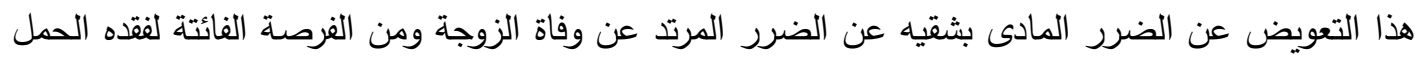
المستكين ، وإذ كان التعويض عن فوات هذه الفرصة يدخل في عموم الضرر المادى فهو فرع لأصل ومن ثن

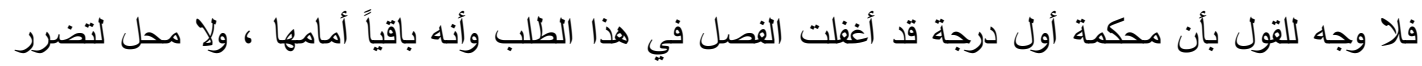
الطاعنة من قضاء الحكم المطعون فيه بالتعويض المادى عن الفرصة الفائتة ، فقد تعرض للفصل فيها عرض على محكمة أول درجة وقضى فيه بما أرتأه ، ومن ثم فإن النعى على الحكم المطعون فيه بهذا الوجه يكون على غير أساس . 
احالة حقوق الحمل المستكن الى القانون رقم 91 السنة 1901 فى شان الولاية على المال بل

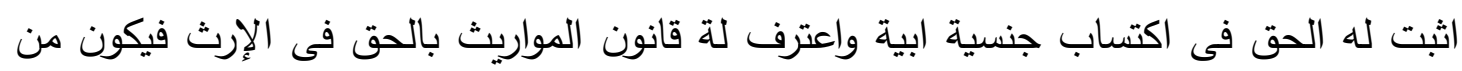

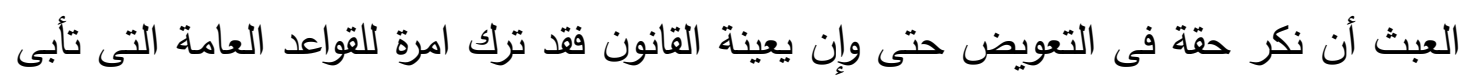

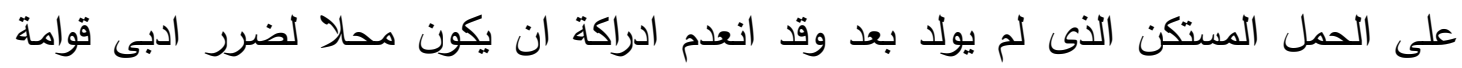
الثعور والعاطفة

• لذلك أري أنه من الغريب تبرير القضاء المصري في عدم إقراره بالتعويض للجنين مدعياً ” أن الحق في التعويض عن الأضرار الثخصية المباشرة التي تدعى أنها أصابتها لم يكن من بين الحقوق التي حددها القانون للحمل المستكن وحددها على سبيل الحصر ولا يتصور أن يصيبها ضرر من جراء وفاة شقيقتها السابق على ولادتها، وإذ خالف الحكم المطعون فيه هذا النظر، وقضى بإلزام الثركة الطاعنة بالتعويض عن الضرر الأدبي الذي أصاب الصغيرة فإنه يكون

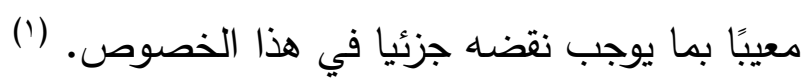

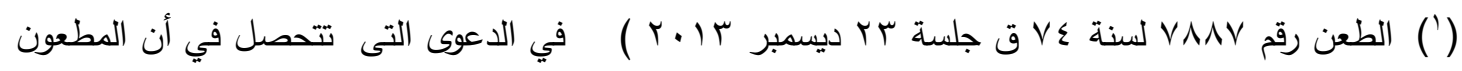

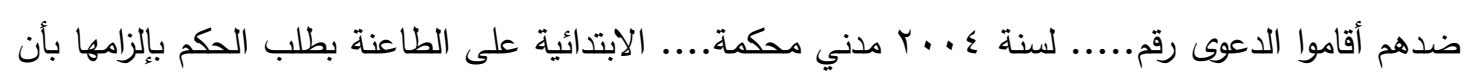

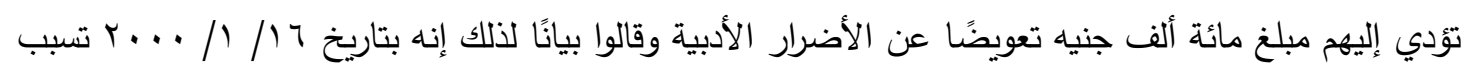

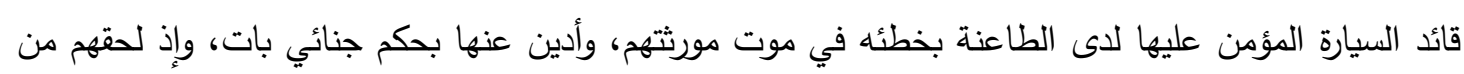

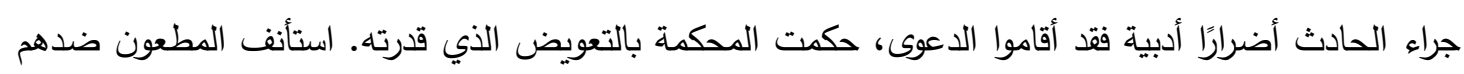

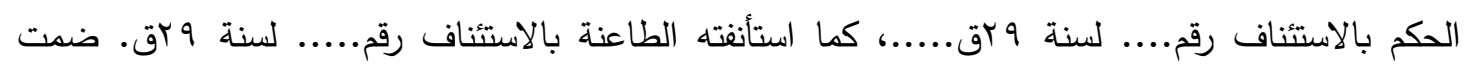

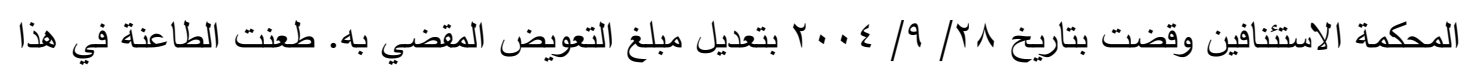

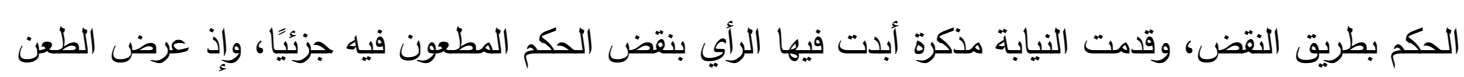

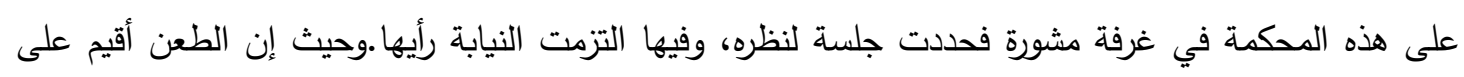

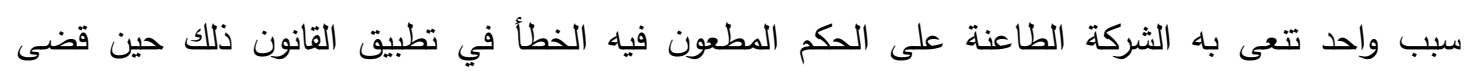

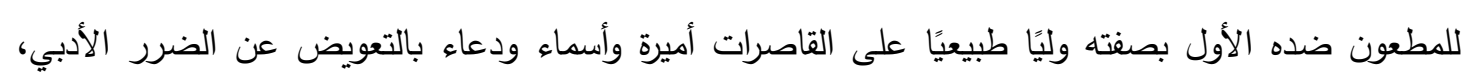

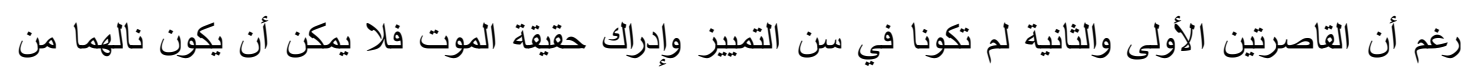

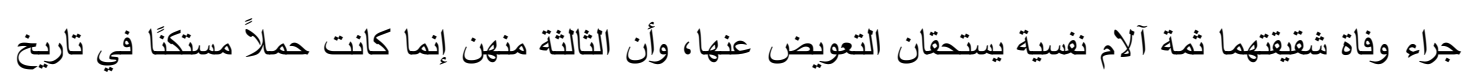

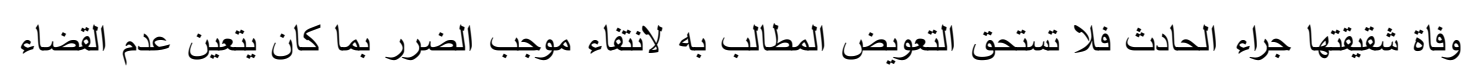

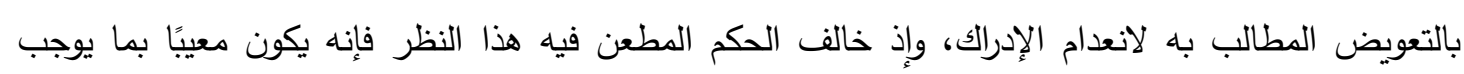


في الحكم الصادر في دعوة تطالب بتعويض الجنين (').

بتاريخ • أ لقد أيد القضاء الفرنسي هذا الاتجاه بوضوح حيث قد صدر في هذا الثأن قرار أكتوبر ع^91 1، جاء في حيثياته الاعتراف في استحقاق الجنين التعويض عن الحادث الذي أودى بحياة الوالد فإن القضاء برفضـه الطلب يكون قد أنكر حقا مكتسبا أقره القانون ومن ثـة أخطأ في التطبيق لذلك أرى أن التعويض عن ضرر الموت ضرورة فرضت نفسها لاسيما في

(') فإن مؤدى نص المادة r (') من القانون المدني أنه يجوز الحكم بالتعويض للأزواج والأقارب إلى الدرجة

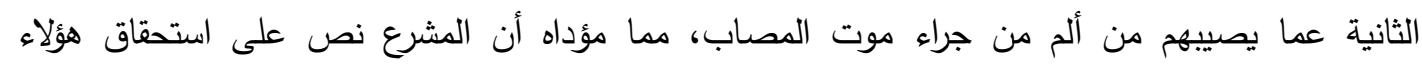

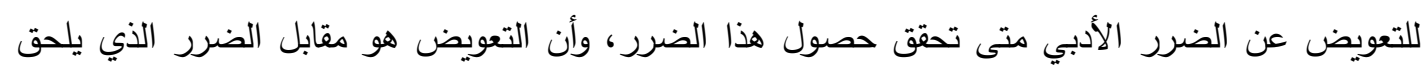

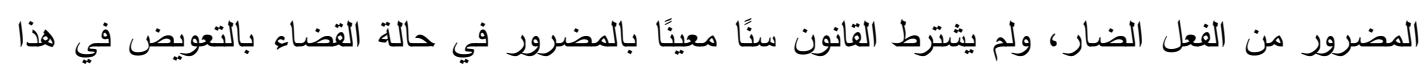

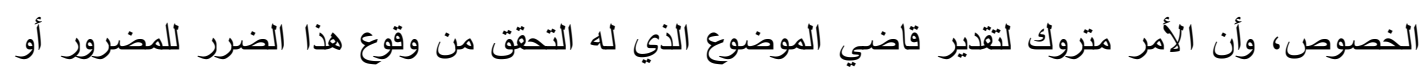

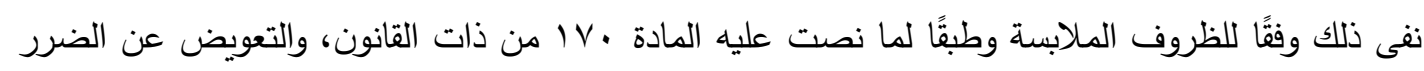

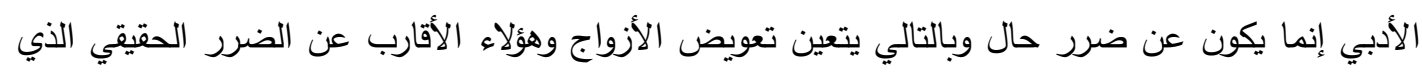

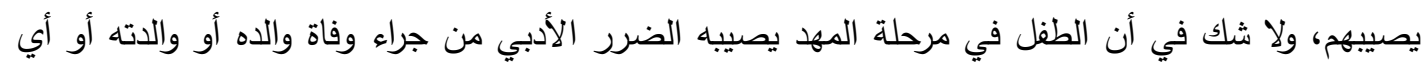
من إخوته لأن الطفل في هذه الحالة يرتبط بمن حوله من هؤلاء ومن الصعوبة فصله عنهم ويتحقق بفراقهم الألم والضرر الأدبي الذي يستحق عنه التعويض، وإذ التزم الحكم المطعون فيه هذا النظر وقضى للقاصني هرتين

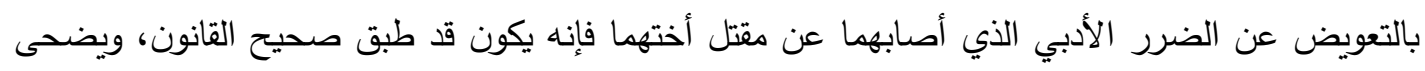
النعي على غير أساس.

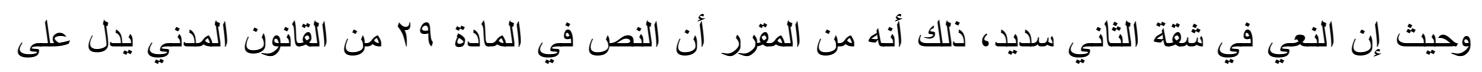

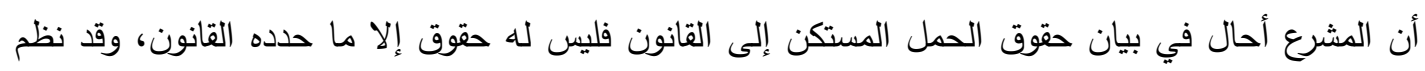

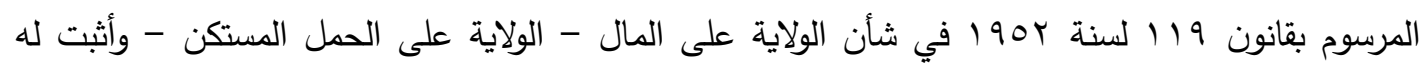

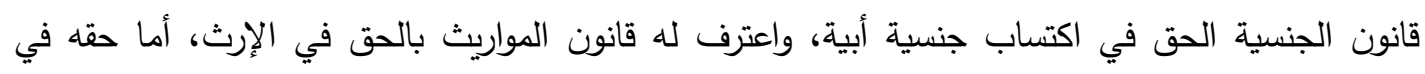

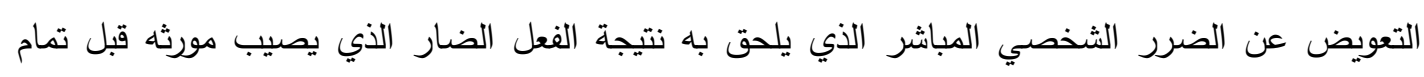

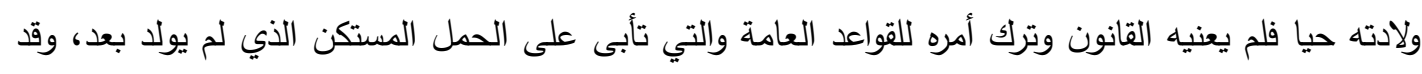

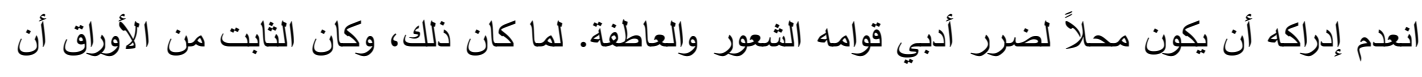

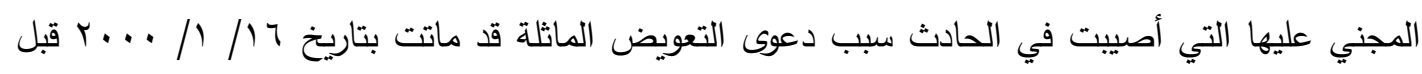

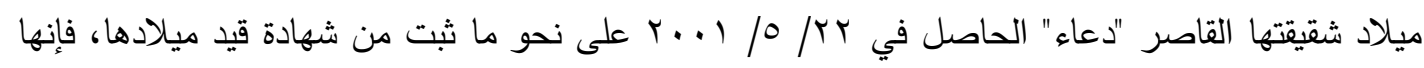

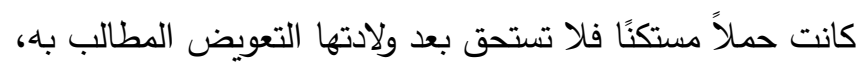
وحيث إن الموضوع فيما نقض من الحكم صالح للفصل فيه، ولما تقدم يتعين الحكم في موضوع الاستئنافين

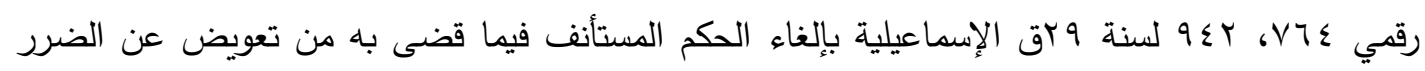

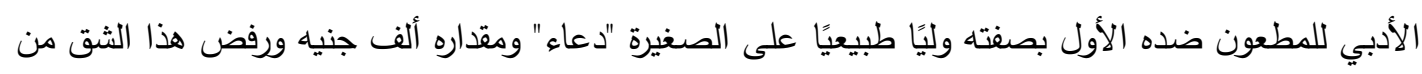


تعويض الأجنة عن الأضرار المدنية دراسة مقارنة بين القانون المدني المصري ، والشريعة الإسلامية

هذا العصر الذي كثرت وتعددت فيه الأضرار وبالتالي الوفاة، هذا من جهة، ومن جهة أخرى

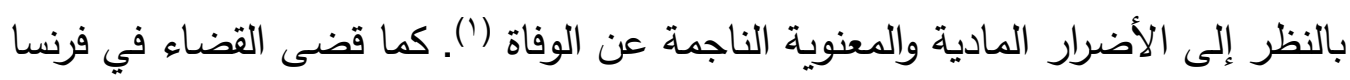

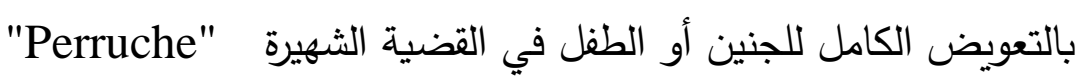
وهو الطفل الذي ولد معاقا بسبب مرض وراثي لم يكثف عنه الطبيب للوالدين في اثتاء الحمل كما أن القضاء الاداري لم يرفض تعويض الجنين اذا كان التدخل الطبي هو السبب المباشر للاعاقة والمرض الذي اصابه وهوجنين لكنه يرفض ذلك اذا كانت هذه الاعاقة او المرض يرجع

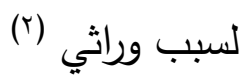

وفي حكم حديث للمحكمة الادارية قضت المحكمة بتعويض للوالدين والطفل ضد مركز طبي لخطأ اثناء الولادة تسبب في ولادة طفل معوق ولم تشرط المحكمة أن يكون الخطأ جسيماً واكتفت بوجود الخطأ الذي أسست عليه المحكة حكمها ـ (r).

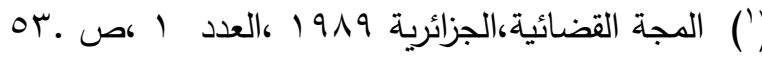

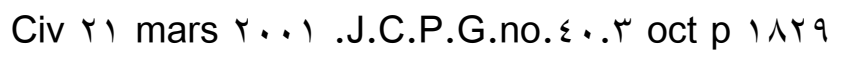

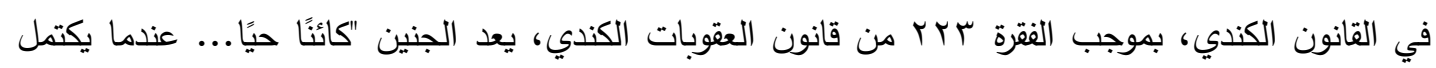

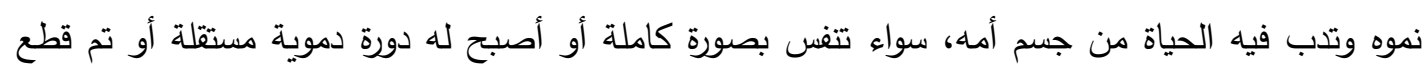

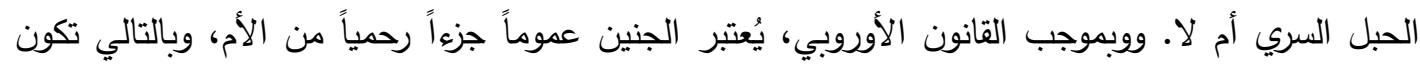

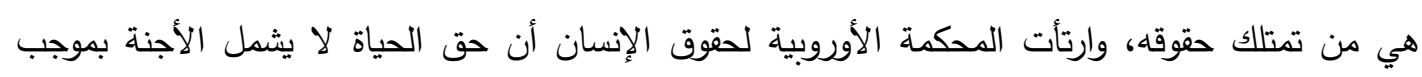

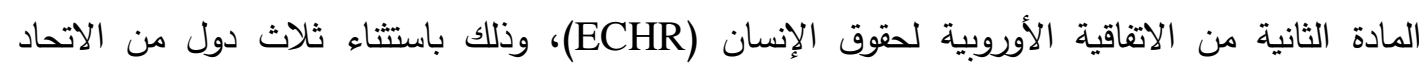

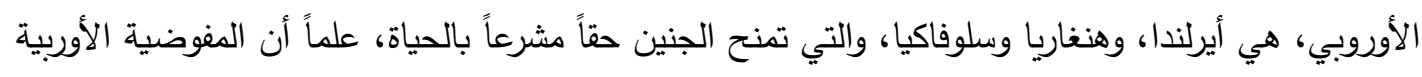

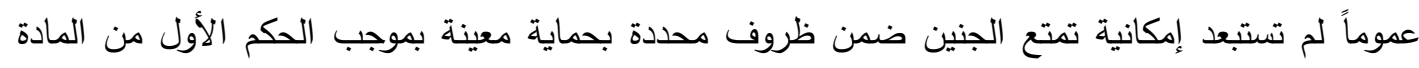
الثانية.

COUR. Adm. Appel paris r-eme ir juin r.. r

تسعى التشريعات أحيانًا لإقرار حق الحياة للجنين منذ لحظة التخصيب. وتعتبر مثل هذه القوانين الجنين

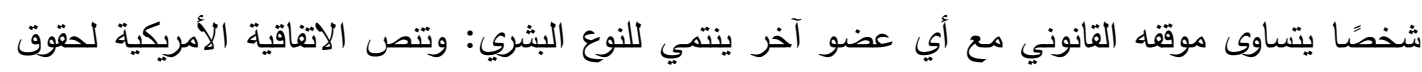

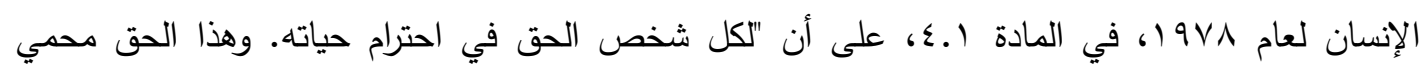

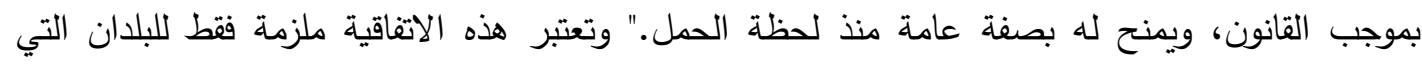

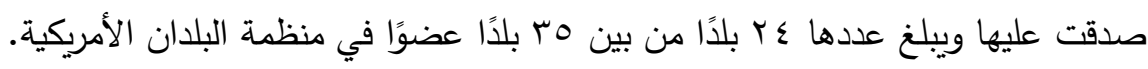


كما قضت المحكمة العليا الجزائرية أن الجنين المولود حيا بعد وفاة والده في حادث المرور يستحق التعويض، وهو ما في قرارها الصادر عن الغرفة المدنية بتاريخ 10 /ع /9 . . ب/ وأهم ما جاء في حيثياته " أن ما تعيبه الطاعنة على القرار المطعون فيه في محله ، ذلك الجنين سيصيبه الضرر جراء وفاة والده ، إذا ولد حيا فإنه و بسبب الوفاة سيفقد معيل له، مما يلحق به

من ضرر (1) (1)

\section{الإلب الثانب}

\section{الاتجاه الثاني رفض اقرار التمعيض للمنين}

حيث ذهب القضاء الى أن إخوة المتوفى الذين كانوا وقت وفاة شقيقهم أطفالاً لا يدركون معنى لفقد أخيهم ولا أثره الأدبي عليهم، فإن الضرر الأدبي لا يتوفر بالنسبة لهم(r) لأنهم أحداث صغار لا يكادون يحسون فواجع الحياة وآلامها (r).

نلاحظ هنا أن القضاء يفرق في اقرار التعويض بين الضرر المادي الذي يسمح بالتعويض عنه وبين الضرر الأدبي فيرفض التعويض عنه للجنين بحجة أنه لا يدرك هول الفاجعة ويقر له بالتعويض عن الضرر المادي لو اصيب به .

وأعتقد أنه من غير المفهوم هذه التفرقة فمن المتصور إن لم يحدث الضرر الأدبي حالاً فإن يتراخى ليحصل مستقبلاً لو توافرت المؤشرات التي تجعل حدوثه في المستقبل أمراً ضرورياً محقق الوقوع كما لا يعني ذلك أن الضرر المرتد الذي يصيب الجنين لا يمكن تصوره في

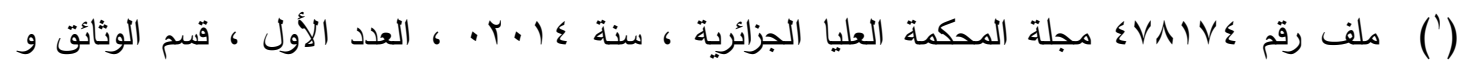

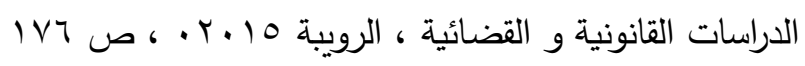

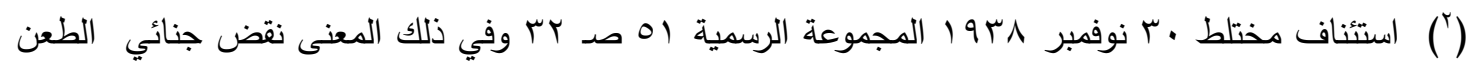

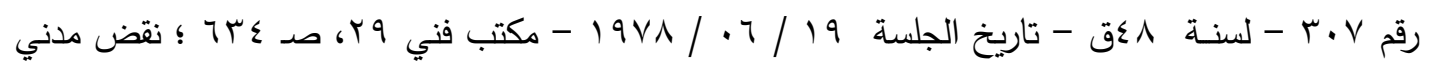

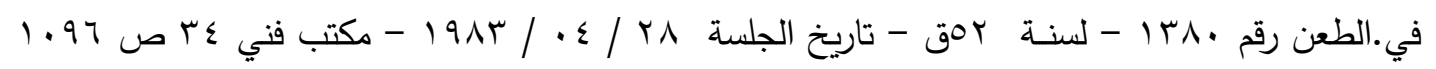

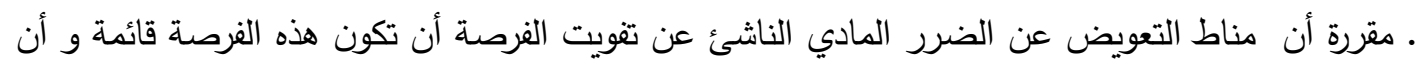

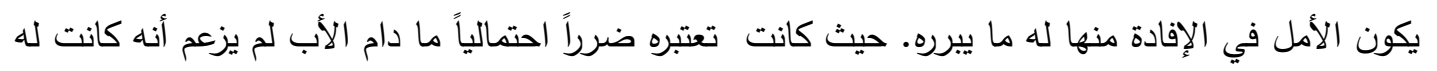

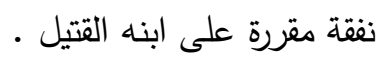

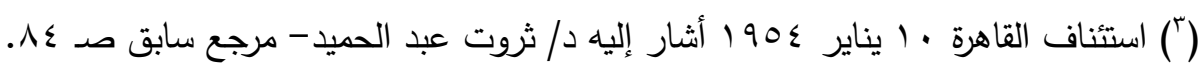




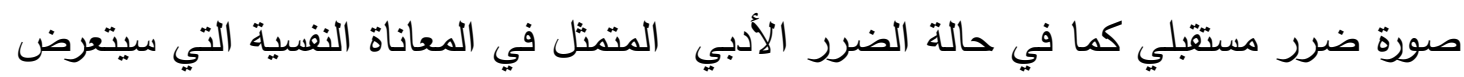

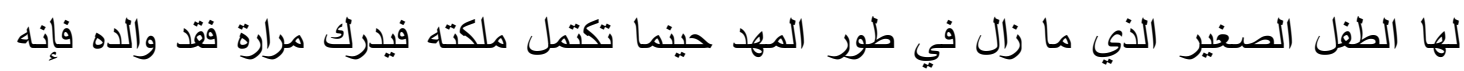

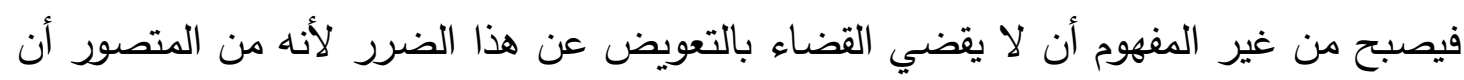

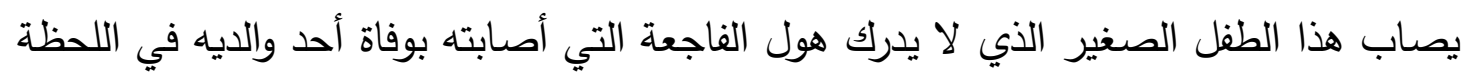

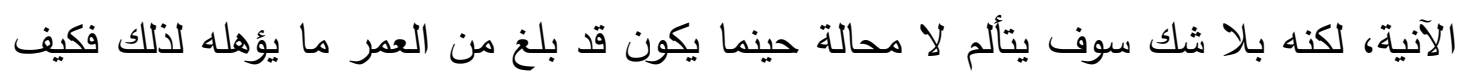

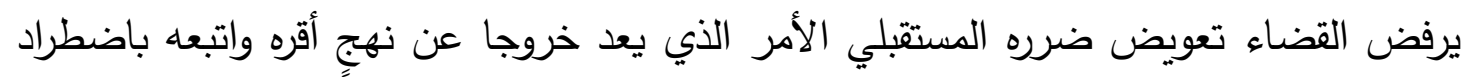

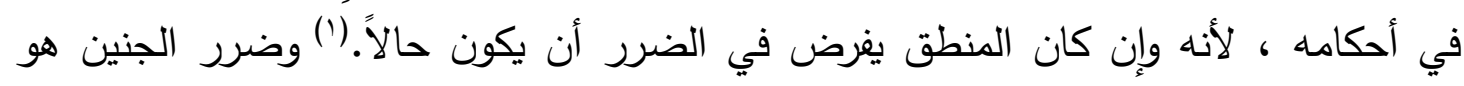

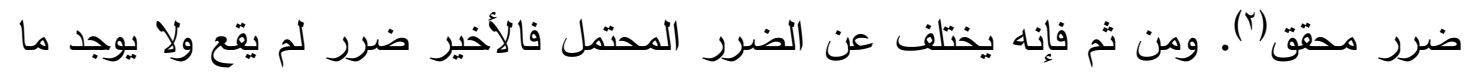

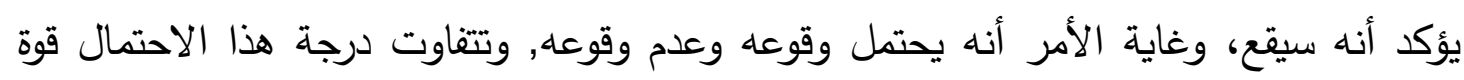

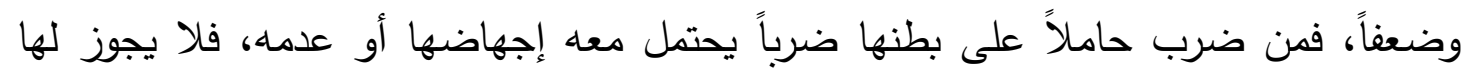

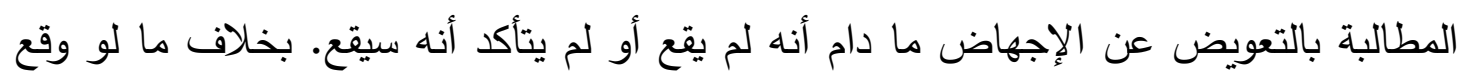

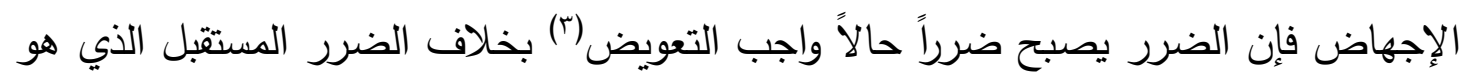

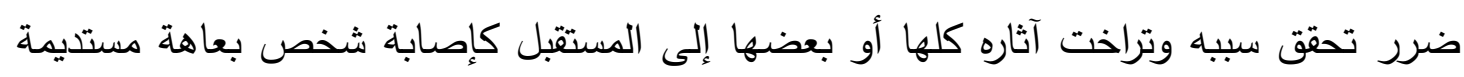

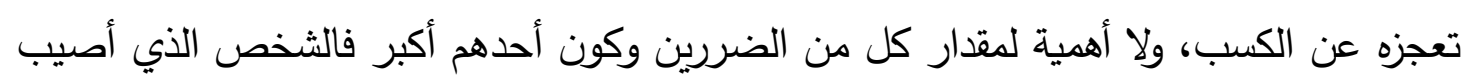

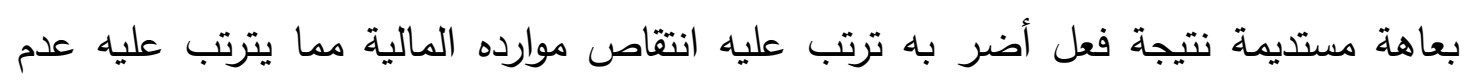

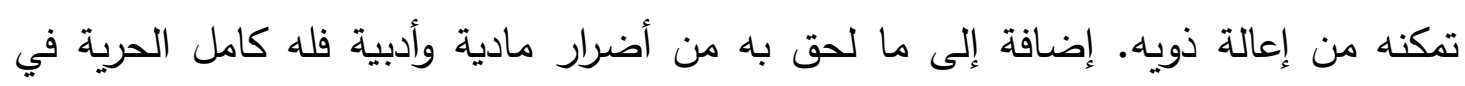
المطالبة بالتعويض، أو عدم المطالبة به فيستطيع مثلا أن يتتازل عن حقه في ذلك، ألكار أو ألا

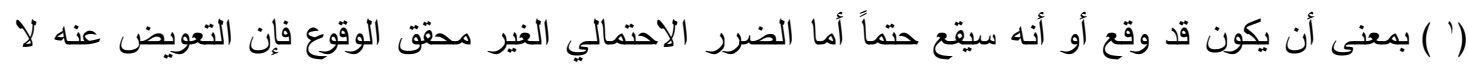

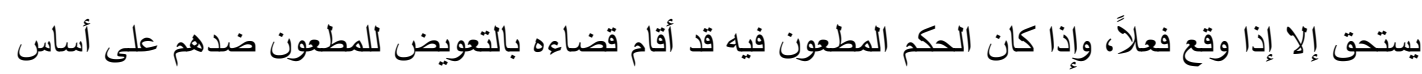

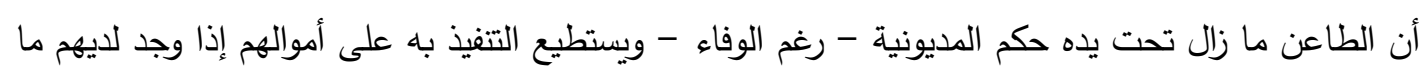

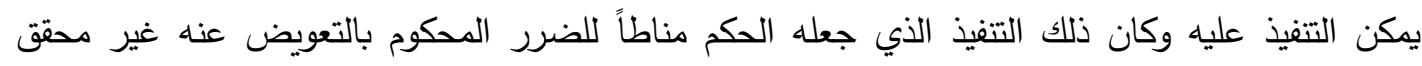

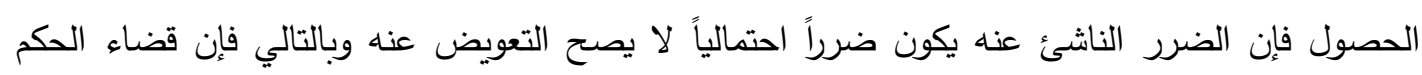
بالتعويض عن هذا الضرر يكون مخالفاً للقانون.

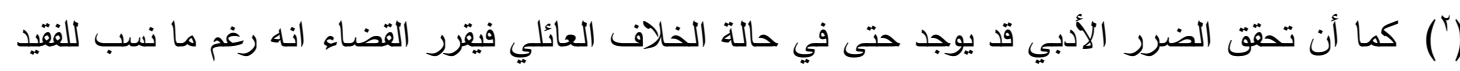

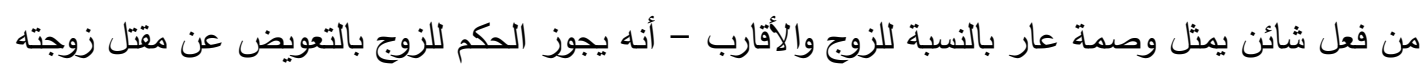

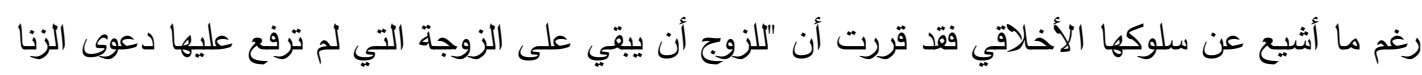

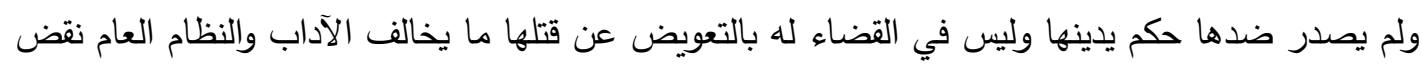

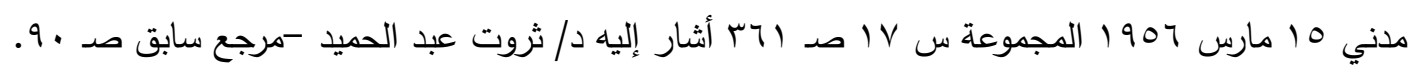

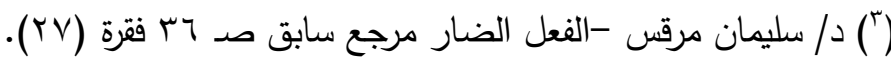


يباشر الدعوى حتى تمر مدة التقادم(1).ومن البديهي أنه ينبغي في الضرر أن لا يكون قد تم تعويضه قبل ذلك. حتى يمكن وصفه بأنه محقق الوقوع(r). و حيث أن قضاة الإستئناف عندما إنتهوا إلى رفض دعوى الطاعنة إستتادا إلى أن وقت الوفاة الجنين كان في بطن أمه لم يصبه ضرر يعد خطأ في تطبيق أحكام ، مما عرض القرار

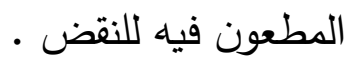

\section{الإلب الثاله}

\section{هموقف النقه الاسلامي من استمقاق الجنين لالضمان}

يقرر الفقه الاسلامي أن الاعتداء على الجنين يؤدي الى الاضرار به مما قد يؤدي الى هلاكه أو انفصال جزء منه كرجل أو يد أو عضو داخلي من اعضائه ومع ذلك يتابع نموه في بطن امه فاذا ما اكتشف ذلك فليس هناك ما يمنع من المطالبة بالتعويض من قبل وليه حتى قبل ولادته ما دام يمكن اثبات ذلك بالاجهزة الحديثة وهو الامر الذي تقره الثريعة الاسلامية قياساً على الانسان المولود فالثريعة الاسلامية ففي اليد نصف الدية وفي اليدين الدية كاملة وعلى ذلك في بقية اعضائه وهو اتجاه الفقه الحنفي (ץ). بينما يشترط الفقه الحنبلي (ع). ان يكون الجنين قد ئ تخلق وعلم انه يده أو رجله بينما يشترط الحنابلة تمامه اربعة اشهر وعند الحنفية يشترطون تمامه ستة اشهر والا ففي اليد نصف الغرة وفيهما الغرة كاملة

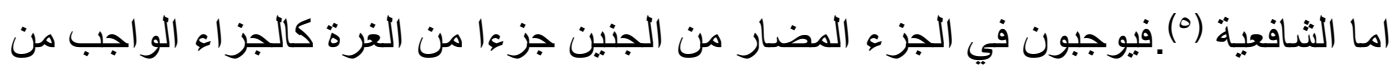
الدية في الجناية على الانسان الحي في الجي

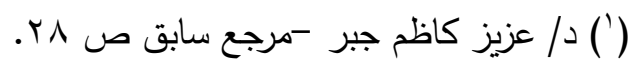

(') Mazeaud (H.J.)et Chabas (F.), Leçons de droit Civil...,op. cit., P.乏) V.

(") جاء " وفي العيون اذا ضرب بطن حامل فأصاب ثد الولد في بطنها فقطعها ثم ولدته حيا ، فنصف الدية

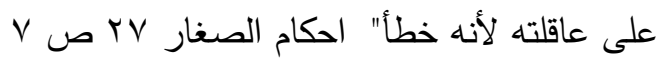

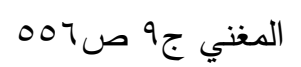

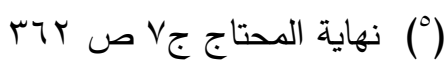




\section{ويعتق الباحث}

من المعلوم بالضرورة أن الطفل تصيبه أضرار شخصية جراء وفاة أبيه حتى لو كان ميلاده في تاريخ لاحق للفعل الذي توفي بسببه الأب وقت أن كان هذا الطفل حملاً مستكناً ، و لا وجه للقول بأن حقه في التعويض مقصور على الحق في التعويض الموروث ، لأن قانون المواريث

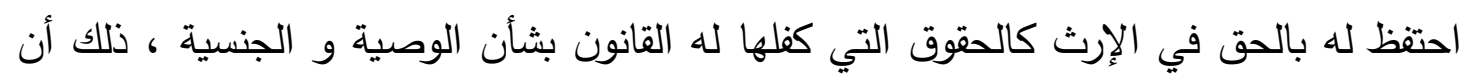

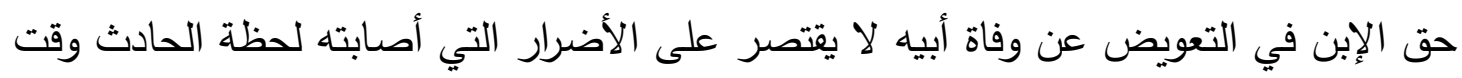
أن كان حملاً ، و إنما يمتد إلى الأضرار التي أصابته بعد ولادته و ثبوت أهلية الوجوب كاملة لله و ما يستجد في المستقبل متى كان محقق الوقوع ، بل و لله الحق في الاحتفاظ بإعادة النظرفي التقديرعملا بنص المادة • V من القانون سالف البيان •

لذلك يعد تكييف المحكمة في رفضها إقرار التعويض للجنين على اعتبار انها قد أقامت الدعوى بعد ميلاد ابنة المتوفي التي كانت حملا مستكناً وقت الحادث و طالبت لها بالتعويض عن الأضرار الأدبية التي أصابتها من جراء وفاة أبيها باعتبارها ابنة له وليست حملاً ، وهو ما قضى به الحكم المطعون فيه ، فإن النعي عليه بهذا السبب يكون على غير أساس ، ولما تقدم

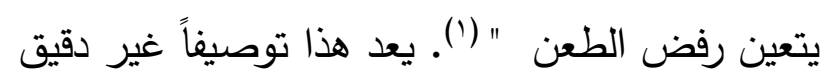

لان تعويض الجنين عن فقد والده ذو شقين شق مادي يتمثل في الضرر المادي الذي يصيب

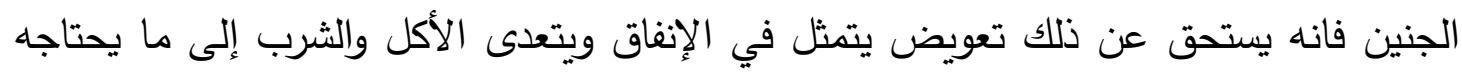

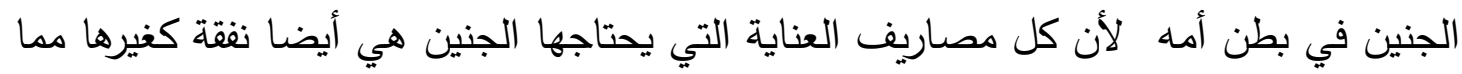
يصرفه الضحية على حاجيات أبنائه قبل وفاته ـ لا يمنع تعويضها بما تستحقه قانونا بعد ولادته

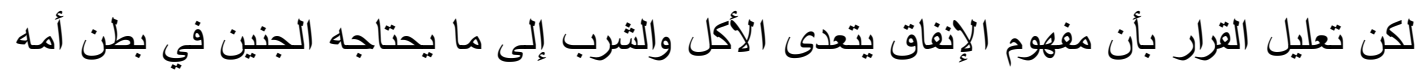

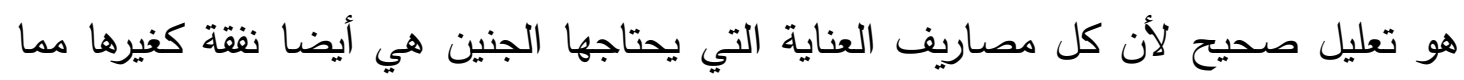

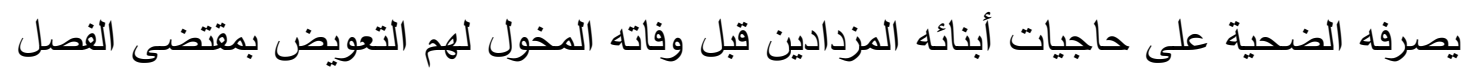

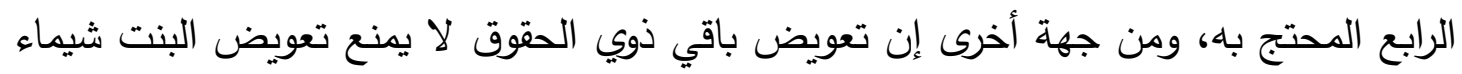

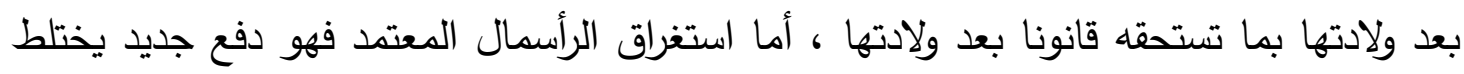


العدد الثامن و الثمانون - الجزء الثانى - إصدار أكتوبر 19 •

فيه الواقع بالقانون ولا تقبل إثارته أول مرة أمام النقض، والوسيلة على غير أساس .

\section{المبمث الخاهس}

\section{انواع الأضرار التى تصيب الجنين ويمكن التعويض منها}

وقسمت هذا المبحث على مطلبين تتاولت في الأول التعويض عن الأضرار المادية التي تصيب الجنين وتتاولت في الثاني التعويض عن الأضرار المعنوية أو الأدبية التى تصيب الإنرال الجنين في بطن أمه:

المطلب الأول : تعويض الجنين عن الأضرار المادية المطلب الثاني : تعويض الجنين عن الأضرار الأدبية

\section{المباب الأول}

\section{تعويض الجنين عن الأضرار المادية}

الجنين وإن كان ناقص الأهلية الا أنه يعد شخصاً طبيعاً له صلاحية التمتع بالحقوق المدنية

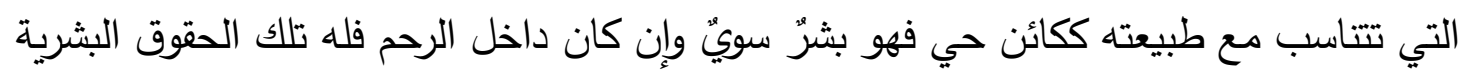

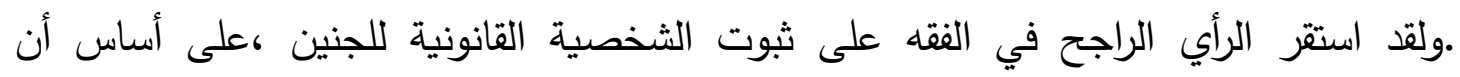

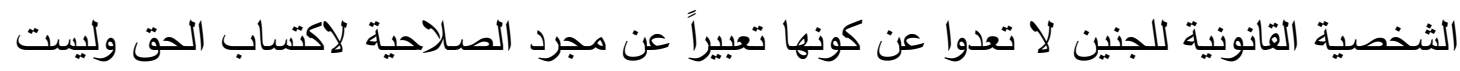
الاكتساب الغعلي للحق ، ولا الصلاحية لاكتساب كل الحقوق ('). الأمر الذي يستتبع الاعتراف له بالثخصية القانونية التي تؤهله لتلقي هذه الحقوق ، بل إنه ما

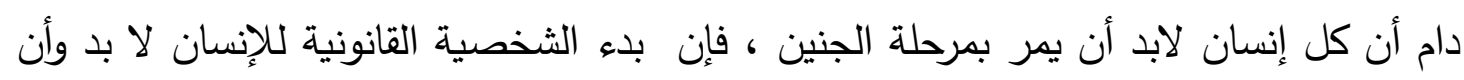

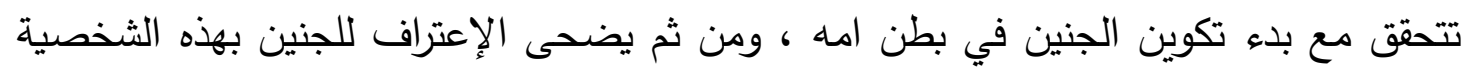
القانونية وهو الأصل وليس الإسنتثاء (「).

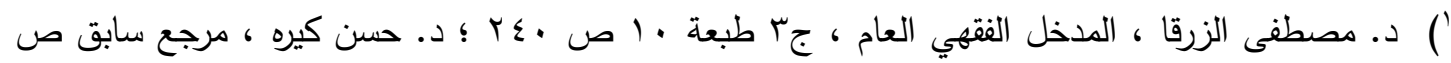

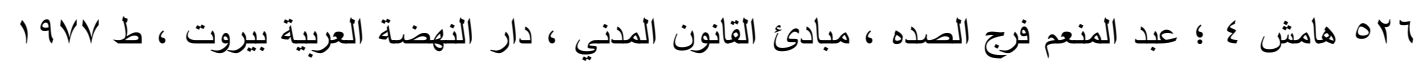

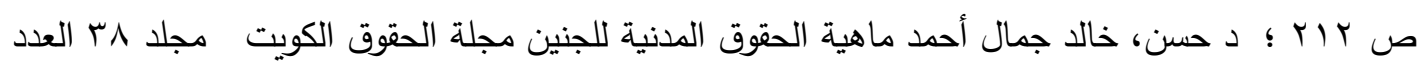
r السنة

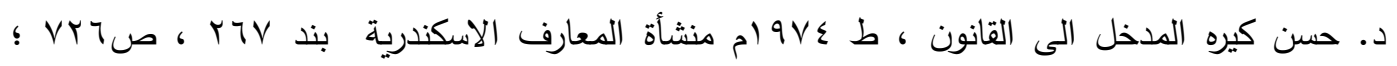

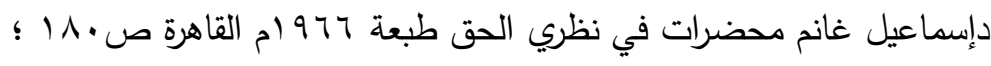


وهذا الإعترف بالثخصية القانونية لا يتنافى مع ما ذهب اليه البعض('). من أن الثخصية

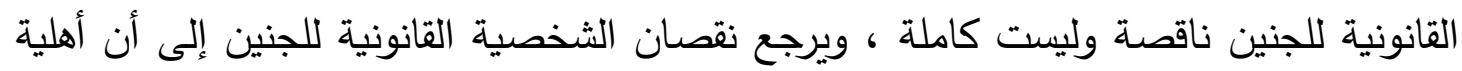
الوجوب لديه ليست كاملة فهي مقصورة على صلاحيته فقط لاكتساب الحقوق دون التحمل

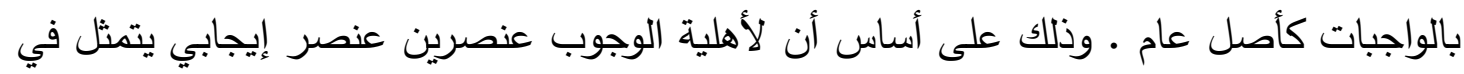

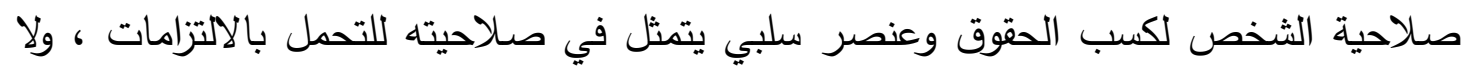

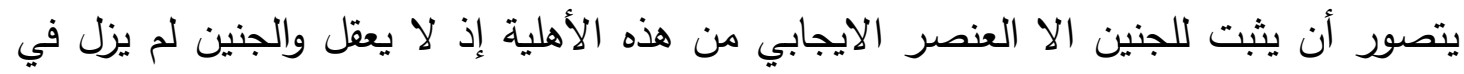

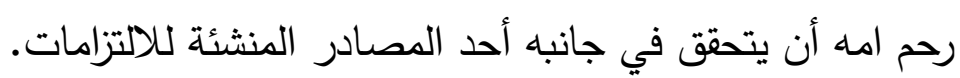
كما أن إقرار الحق في التعويض للجنين لا يتنافى أيضاً مع ما ذهب اليه رأي ثالث من أن :

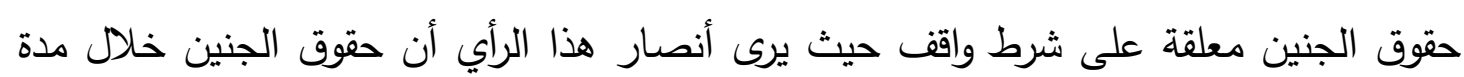

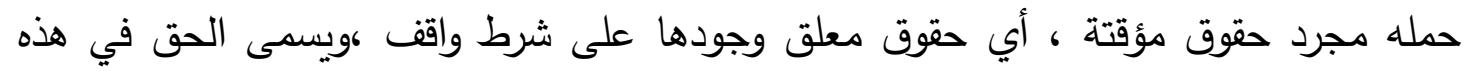

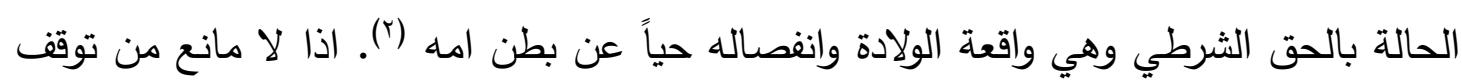
منح التعويض على شرط ولادته وانفاصله عن إمه . كما أن الرأي القائل بأن حقوق الجنين حقوق معلقة على شرط فاسخ: الأوهو عدم ولادة الجنين

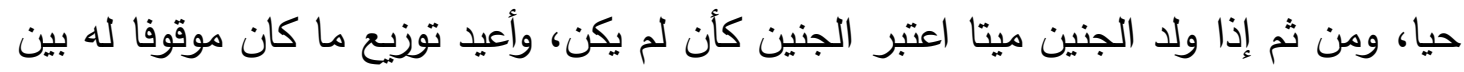
ورثة مورثه وليس بين ورثته هو كجنين (r). أو الرأي القائل بأن حقوق الجنين حقوق احتمالية: أي ليست حالة وغير موجودة - احتمالية -

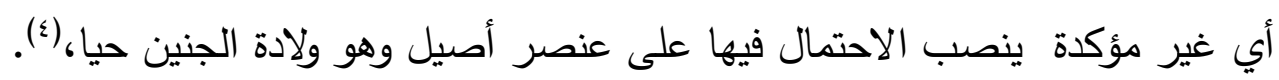
كل هذه الآراء لا تمنع من استحقاق الجنين للتعويض عن الأضرار التى تصيب الجنين في بطن

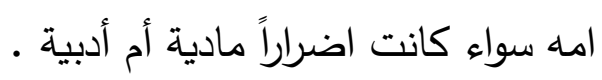

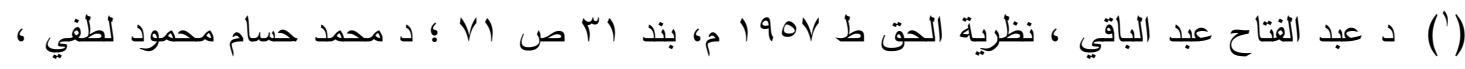

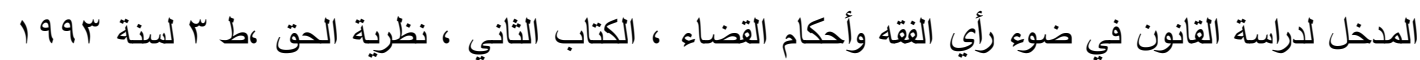

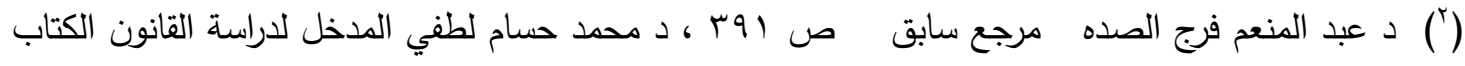

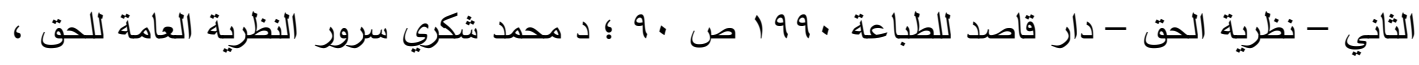

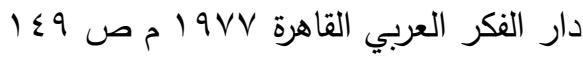
(") د. عبد الحي حجازي - المدخل لدراسة القانون جr الحق وفقاً للقانون الكويتي دراسة مقارنة مطبوعات

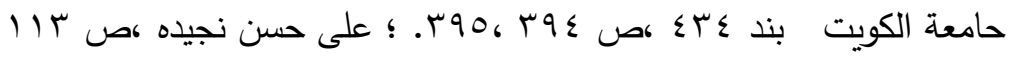

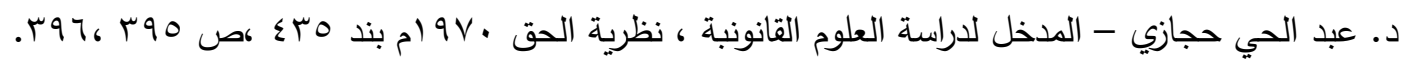




\section{الفرع الأول}

\section{تعميض الجنين عن التشهمات الثاقية}

الثريعة الإسلامية والقوانين الوضعية تمنعان الإعتداء على الجنين في أي مرحلة من مراحل

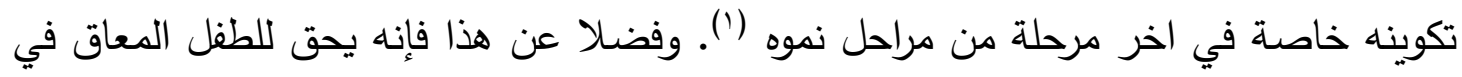

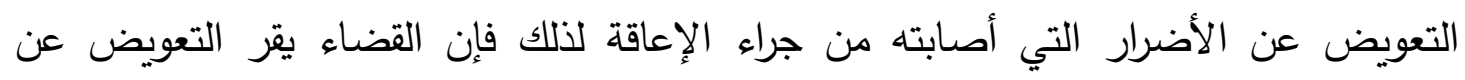
الأضرار الناتجة عن التشوهات الخلقية التى تصيب الجنين، وتطبيقا لاتفاقية فرساي بفرناء لإنساء

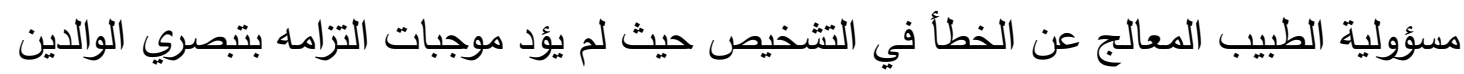

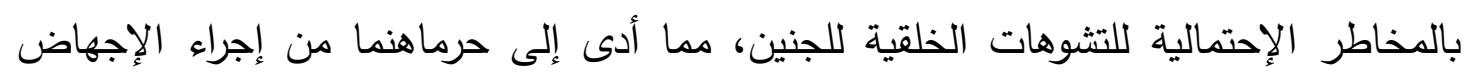

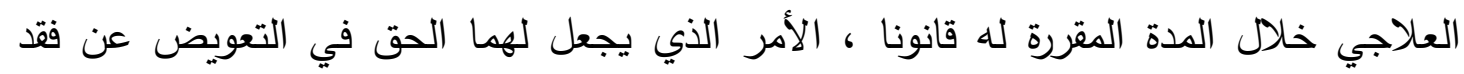

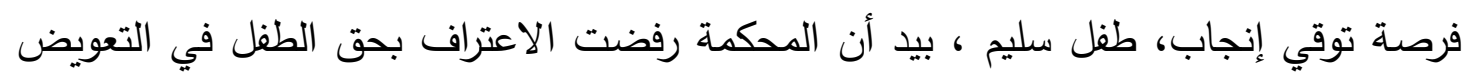
عن ولادته معاقا لأن السبب في إعاقته لا يرجع إلى خطأ الطبيب إنما يرجع إلى الخلى الخلل في الكروزومات وهو سبب داخلي بين الطفل وأمها(؟).

ولقد رفضت المحاكم الفرنسية في البداية الكثير من من أحكامها تعويض الطفل عن ميلاده معاقاً

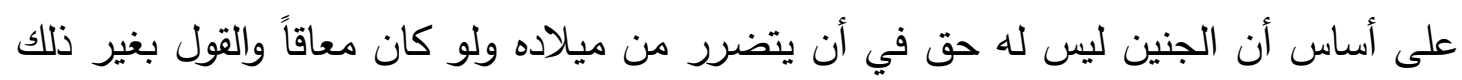

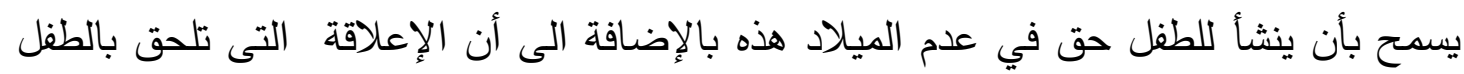

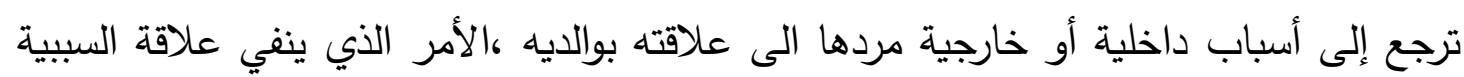

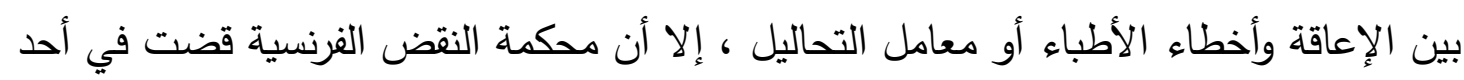

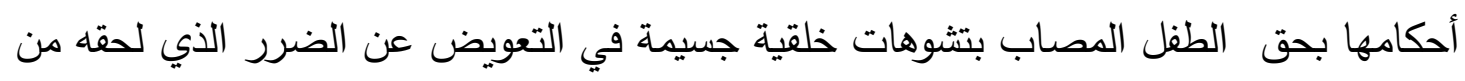

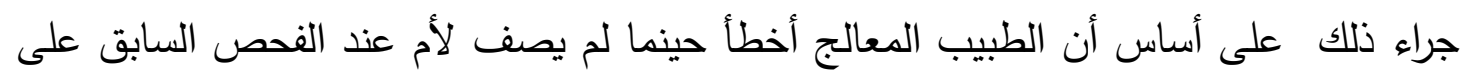

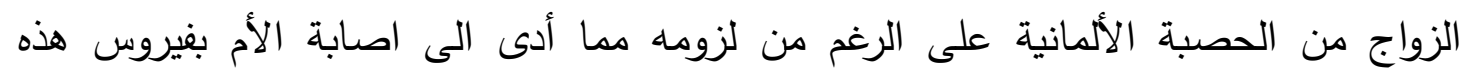

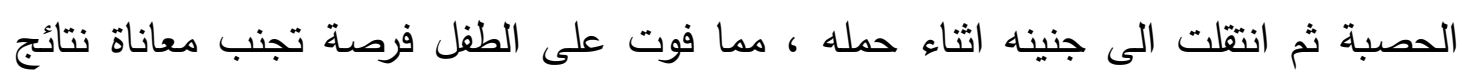

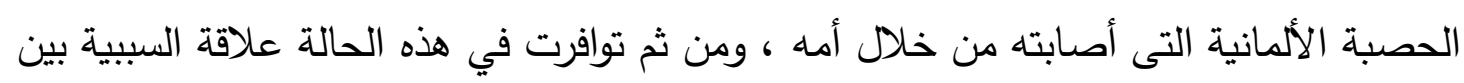

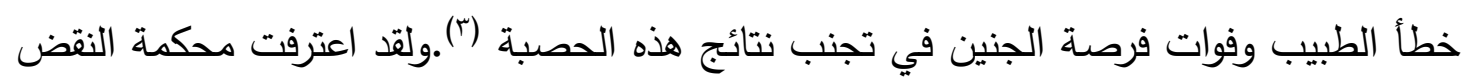

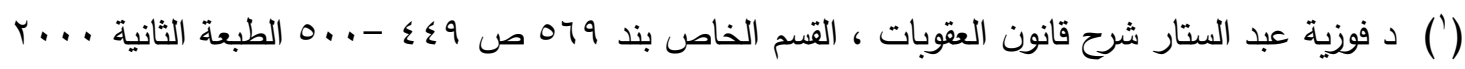

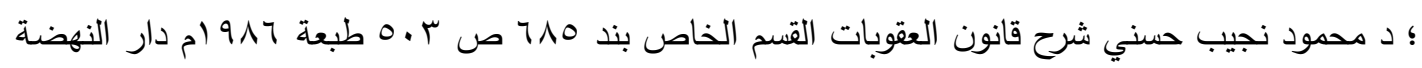

العربية

$\left({ }^{\top}\right)$ C. A. Paris. $1 \vee$ déc. 1994 , D. 1990 somm., p. $9 \wedge$, note Jean Panneau. $\left({ }^{r}\right)$.Cass civ la premiere 17 juillet 1991 -j.c. $p=199 r=11-r \mid 9 \leq \vee$ 


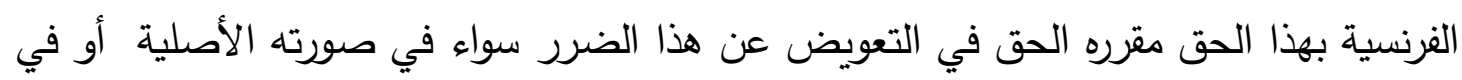

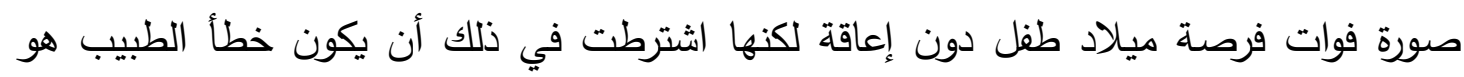
الذي أدى إلى هذا الضرر (').

كما قضت محكمة الاستئناف بفرساي بفرنسا بمسؤولية الطبيب المعاجل عن الخطأ في

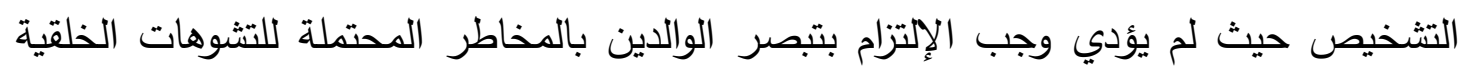

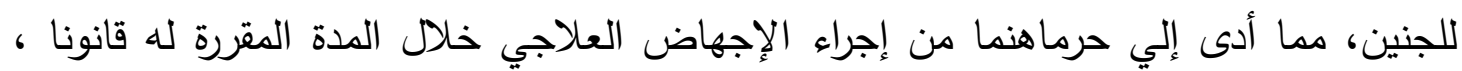

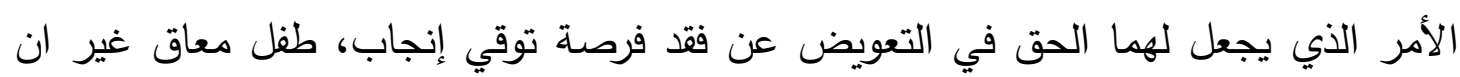

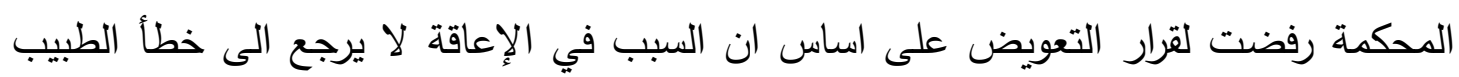

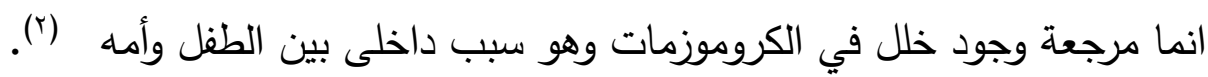
وتنعقد مسؤولية الطبيب أو معامل التحليل عن الخطأ في التشخيص الذي يكثف عن وجود تشوهات خلقية أو أمراض وراثية بالجنين (†).

(') Cass.Civ. 'er 17 juill. 1991, J.C.P. 199 Y, II, No. Y $19 \leqslant \vee$, note Dorsner Dolivet . أن خطأ الطبيب المتمثل في عدم طلب perruche Nicolas لذلك قضت المحكمة في قضية .

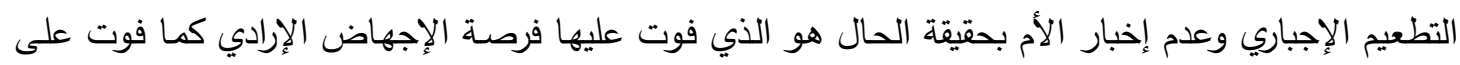

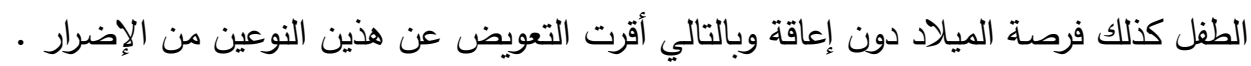

ينظر في ذلك 91 .Cuor d'appel de verssai ^ juillet 199

(") د. ثروت عبد الحميد "مدى الميؤولية عن الخطأ في اكتثاف تشوهات الجنين وأمراضه الوراثية" بحث مقدم

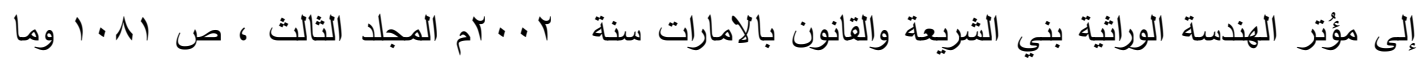




\section{الفرع الثاني}

\section{مدى حق الجنين في الرجوع على والدية بالتعويض عند تشههه في هرماة}

\section{الهمل}

يرى البعض انه لا مانع من تقرير مسئولية الوالدين تجاه الطفل المعاق اذا ثبت تقصيرهما أو إخلالهما بالإلتزامات الطبية التى توجب إجراء بعض الفحوصات الدورية على الجنين ومتابعة ظروفه الصحية خلال فترة حمله مما أدي الى إصابته باعاقة جسدية أو عقلية لمسئوليتهما المدنية عن تعويض طفلهما المعاق (').

مدى حق الطفل في الرجوع على والديه بالتعويض إذا آتخذا قرار إنجابه رغم تبصير الطبيب

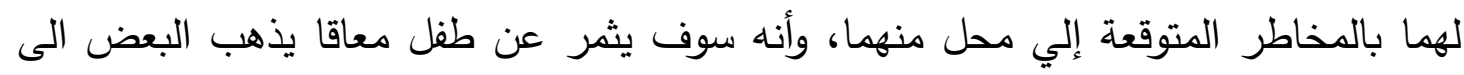

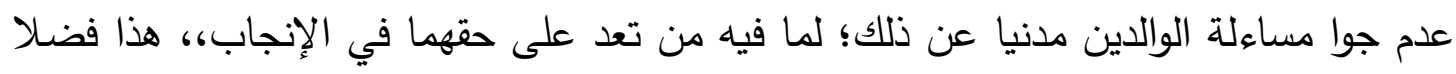

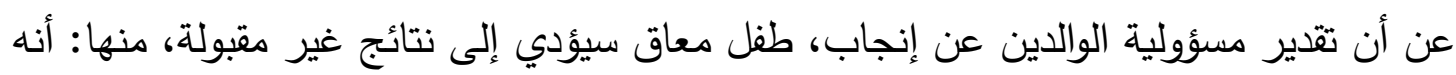

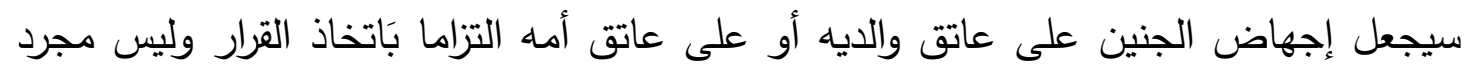

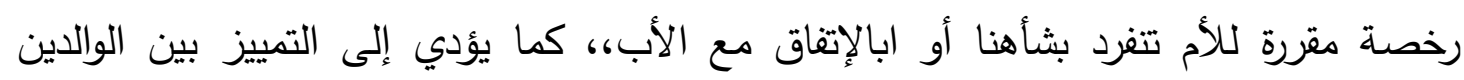

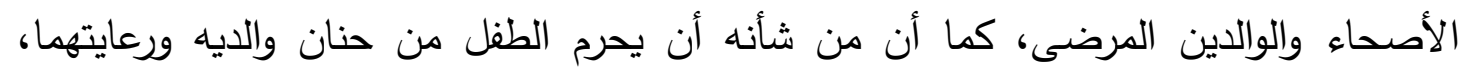

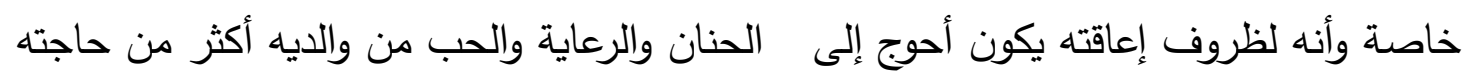

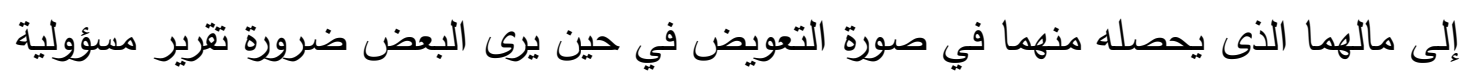

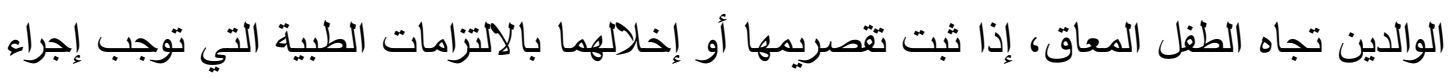

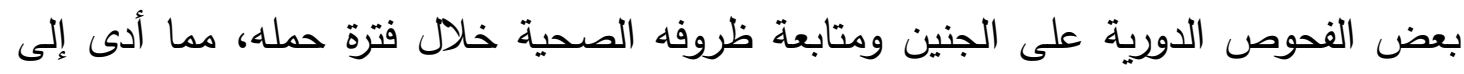

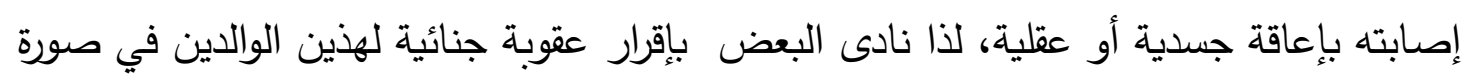

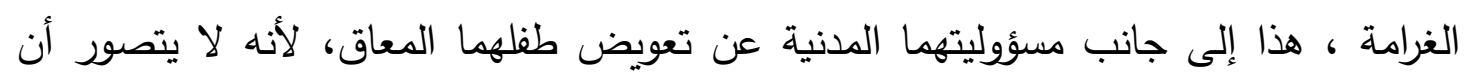


تعويض الأجنة عن الأضرار المدنية دراسة مقارنة بين القانون المدني المصري ، والشريعة الإسلامية

تكون دعوى تعويضه في مواجهة الطبيب أو المعمل أو المستشفى مقبولة، في حين أن دعواه لا تكون مقبولة في حق الوالدين، على الرغم من أنهما قد تسببا في إعاقته مثلهم (').

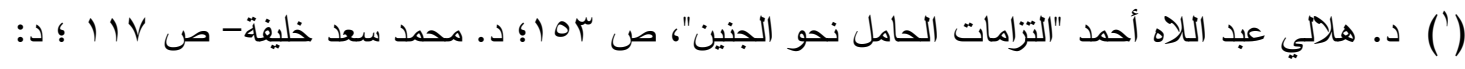

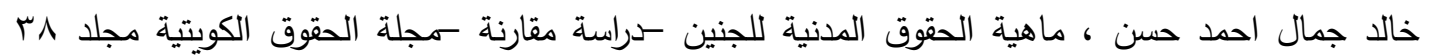

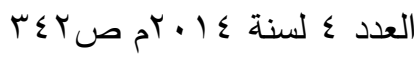




\section{الفرع الثالث}

\section{الشريعة الإسلامية تضمين الجنين عن ضرر القتل بتقرير الغرة}

يرى جمهور الفقهاء أن الغرة تستحق عن موت الجنين لورثته الثرعيين مثلها مثل الدية وهو ما

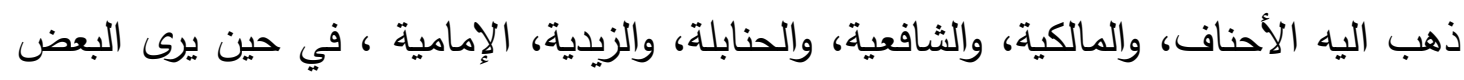

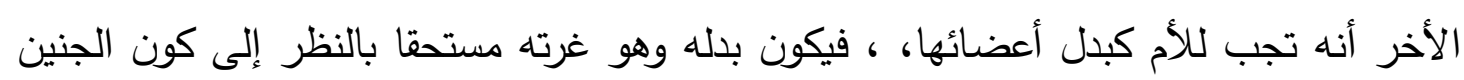

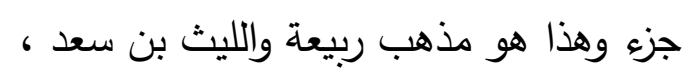

بينما يذهب رأي آخر إلى أنه إن وقعت الجناية قبل مائة وعشرين يوما كانت الغرة ألمه، وان وقعت بعد هذه المدة كانت الغرة حكم المواريث، وهذا هو رأي الظاهرية وقيمة الغرة، والتي تقدر بنصف عشر دية الرجل إن كان الجنين ذكرا وعشر دية الأنثى إن كان

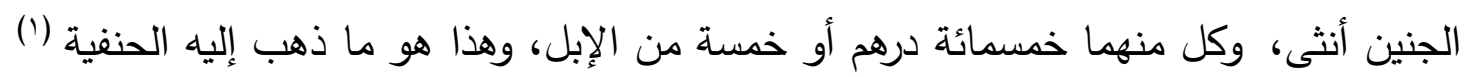

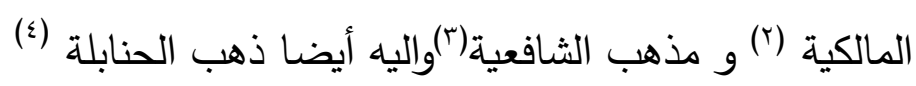
واجمع الفقهاء على انه: " إذا شربت الحامل دواء فألقت جنينها، فعليها غرة، لا ترث منها شيئ

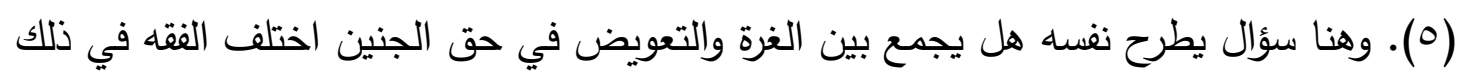
على اتجاهين : (0)

الاتجاه القائل بالازدواجية في الجمع بين الغرة والتعويض لاثكك أن تطبيق القوانين الوضعية المأخوذة من الدول الغربية أبان استعمارها وإحلاله

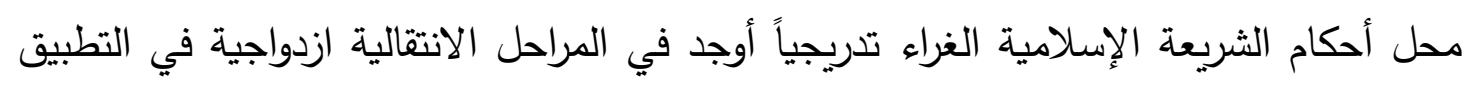

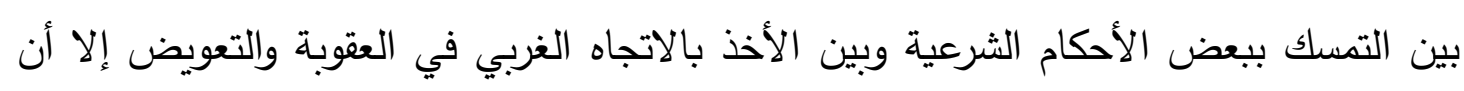
الأمر لم ييق على هذا الحال بل وجد اتجاه عند الباحثين المعاصرين بالفقه أجاز هذه الازدواجية لإنداه

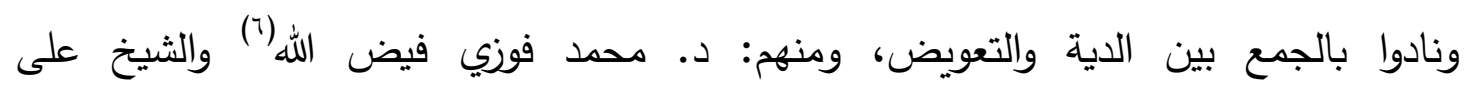

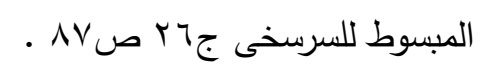

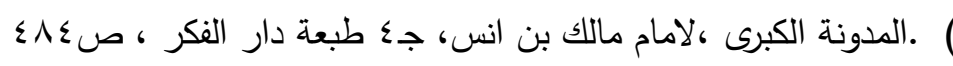

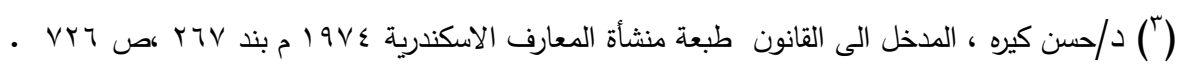

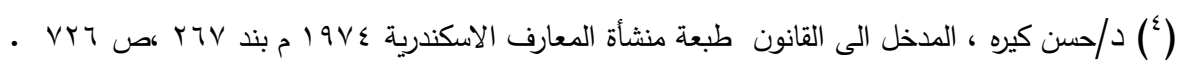

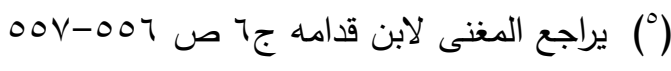

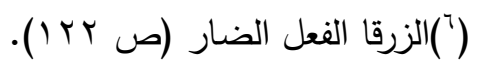


الخفيف(').وقد انطلقوا من جواز أخذ الزيادة على الدية (r) في قولهم بالجمع بين التعويض والدية

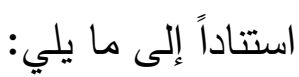

ما قرره الفقهاء في أرش الألم.حيث سمح بأن يتقاضى الثخص المصاب الذي اندملت جراحه

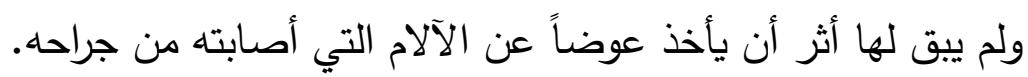

مراعاة لقاعدة عموم رفع الضرر .فقاعدة عموم رفع الضرر تقتضى أن يعوض تعويضاً كاملاً كل من أصيب بضرر سواء كان ضرراً مادياً أو معنوياً r- ترك أسباب التظليظ وتقدير الواجب بكل سبب من قبل القضاة مراعاة للظروف المتتوعة للمتقاضين وقوة العدوان.

ع- أن الدية لم تشرع تعويضاً كاملاً عن جميع ما يصيب المجني عليه، فلا تمنع القول بجواز

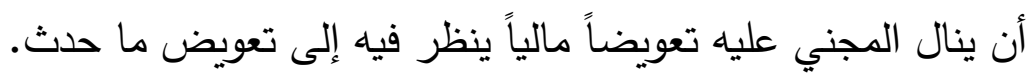

ه- إن في شرع التعويض إرضاءً للنفس وزوال للحقد ما لم يلاحظ في تشريع الدية فجاز أن يضم إلى الديات ما يرى وجوبه من تعويض مالي.

\section{الاتجاه الثاني : الاتجاه القائل بالإفراد بين الغرة والتعويض}

لما نظمت القوانين الوضعية الخاصة وطبقت في البلاد العربية تطلب الأمر تكييف

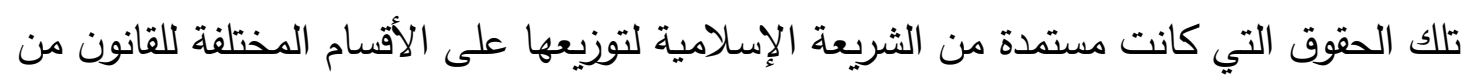

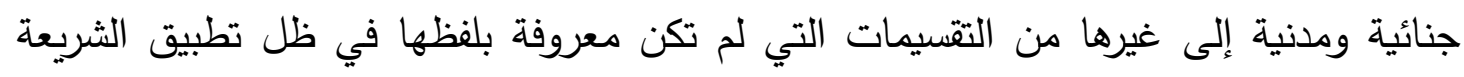

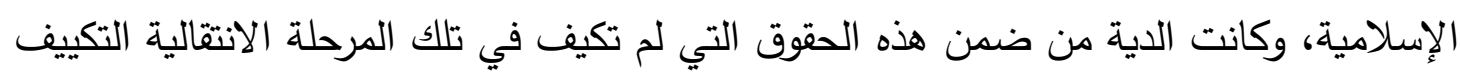

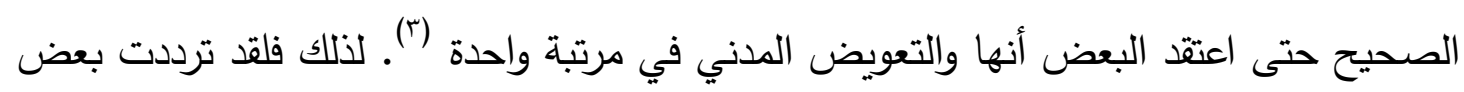

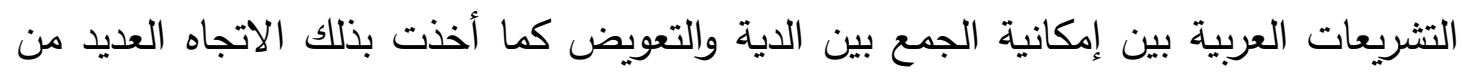

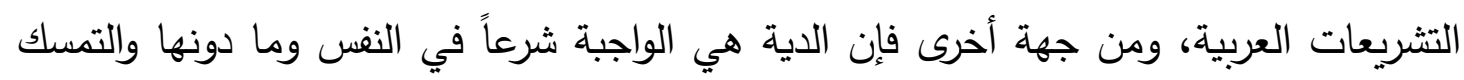
بالثريعة وما فصلته من أحكام يقتضي القول بالإفراد بعيداً عن التأثر .

$$
\begin{aligned}
& \text { (') (الثيخ علي الخفيف-الضمان في الفقه الإسلامي، (ص • (با) وما بعدها. }
\end{aligned}
$$

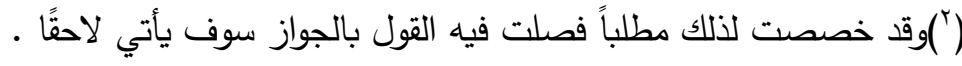

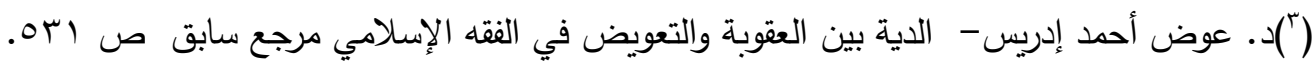




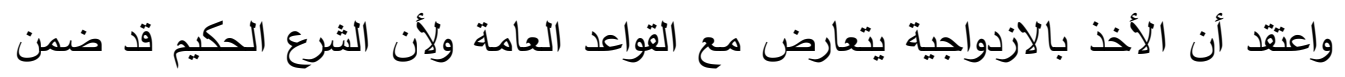

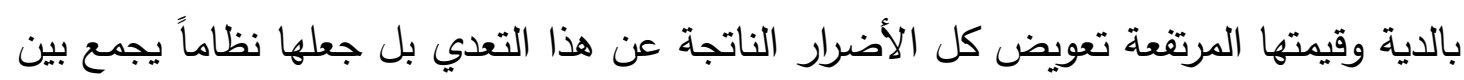

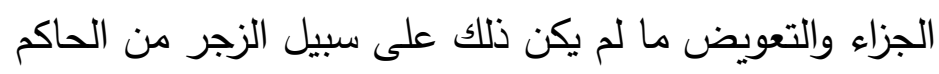
وتطبيقاً لذلك جاء نص المادة r r عقوبات مصري على أن: المرأة التي رضيت بتعاطي

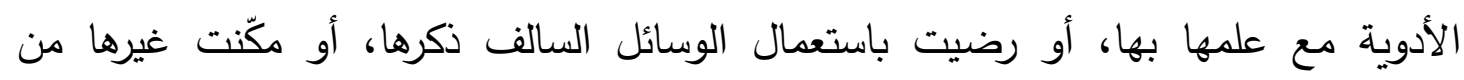
استعمال تلك الوسائل لها، وتسبب الإسقاط عن ذلك حقيقة، تعاقب بالعقوبة السابق ذكرها."( (1). والجنين الذي توفي والده اثناء فترة الحمل ارى انه احوج من غيره في تعويض الضرابل الضرر بنوعيه

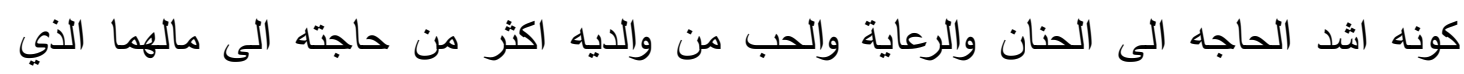
يحصله منهما في صورة التعويض (؟). 


\section{الإلب الثانى}

\section{تعميض الجنين عن الأضرار الأدبية}

عرف الفقهاء المعاصرون الضرر الأدبي بأنه : ما يصيب الإنسان في شعوره أو

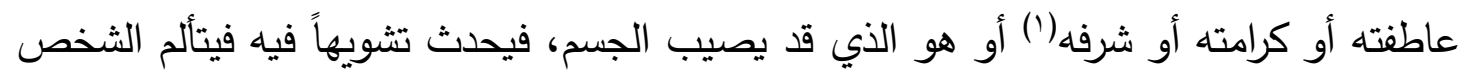
للذلك، أي انه عبارة عن الألم والحزن الذي يصيب الإنسان ويمكن تعريف الضرر الأدبي للجنين بأنه كل ما يصيب الجنين من ألام في شعوره

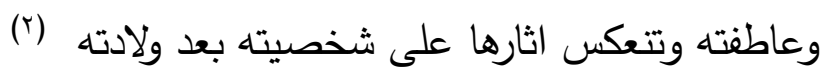

وذهب جانب من الفقه الفرنسي الى عدم استعمال مصطلح الضرر الأدبي أو المعنوي

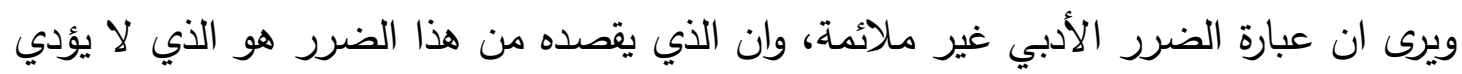

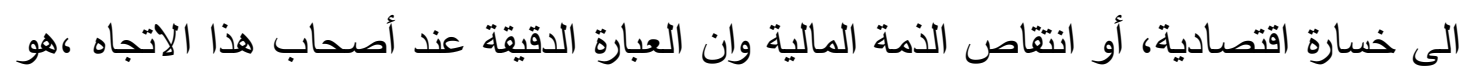

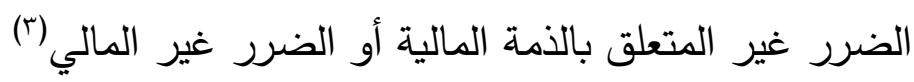

ومن الاضرار التى تصيب الجنين الضرر المعنوي أو النفسي أو الأدبي وهي ثلاثة

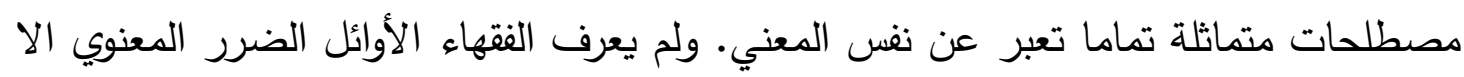
أن شراح القانون سعو إلى تعريف الضرر المعنوي بوجه عام ويمكن لنا تعريف الضرر الادبي الإني

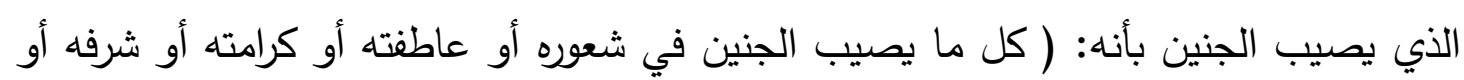
أي معني آخر من المعاني التي يحرص عليها أو هو : الضرر الذي يصيب مصلحة غير فير مالية للجنين

ويكون الضرر المراد التعويض عنه في حق الجنين محققاً بأن يكون الضرر قد وقع

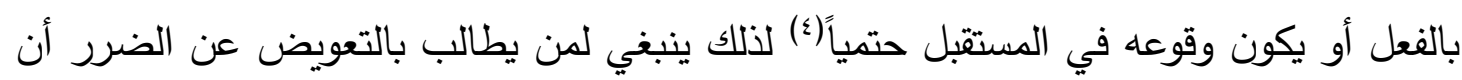

وهبه الزحيلي، التعويض عن الضرر بحث منشور في مجلة البحث العلمي والتراث الإسلامي، كلية

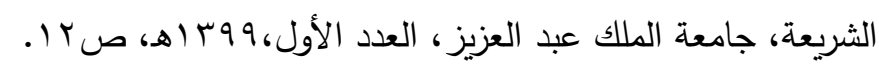

الباحث

(") Boris Starck Droit civil obligationParis l qvr p or

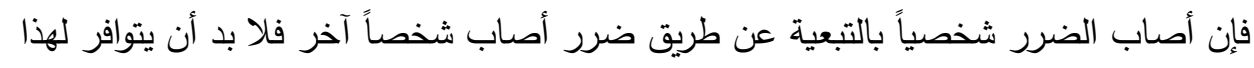

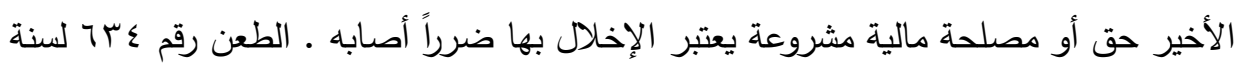

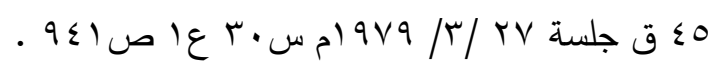


يكون هذا الضرر قد وقع بالفعل أو وقوعه حتمي لا محالة('). فلا يشترط في الضرر أن يكون

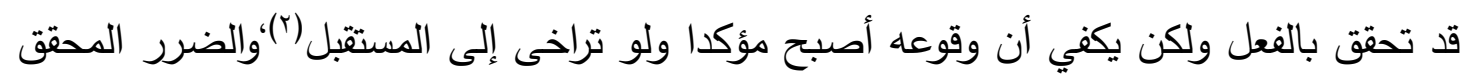
الذي يصيب الجنين قد يكون ضرراً مادياً(؟) وهي الخسارة المادية التي تلحق المضرور سوراء كان ذلك يشمل ما لحقه من خسارة وما فاته من كسب(๕). كما يشمل الضررالادبي الذي يصيب الجنين فيشمل الآم والمعاناة وحزن الفراق للضحية المباشرة(ْ). وقد يكون الضرر الذي يصيب الجنين ضرراً مستقبلاً ولا يمنع هذا التعويض عنه لأن الضرر المستقبل ضرر تحقق سببه وتراخت آثاره كلها أو بعضها إلى المستقبل فيكون في حكم الضرر المحقق ويستبع المسئولية والتعويض وقد أخذت محكمة النقض بذلك(؟).غير أن الضرر المحتمل لا يقبل التعويض وهو ما استقر عليه قضاء النقض في كل من مصر (Y). كما أن الفقه والقضاء الفرنسي التجأ في تأصيله لاقرار حق الجنين في التعويض الى ما اقره القضاء(^) والفقه الروماني في مبدأ موروث تنص على أن الجنين يعتبر مولوداً كلما كان الحدث في مصلحته وذلك بغية التغلب على

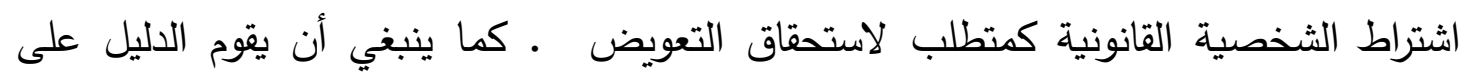

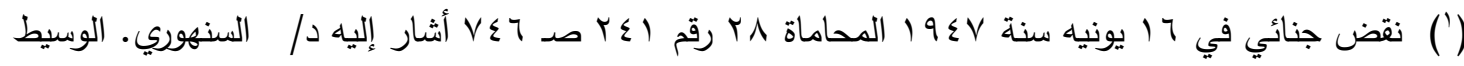

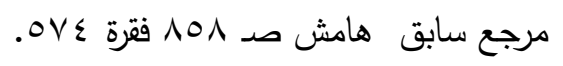

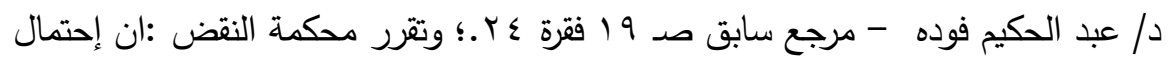

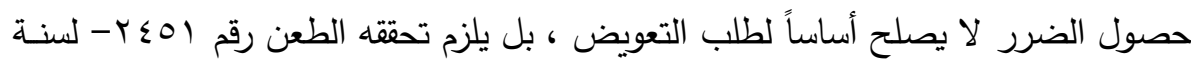

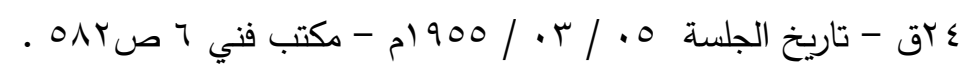

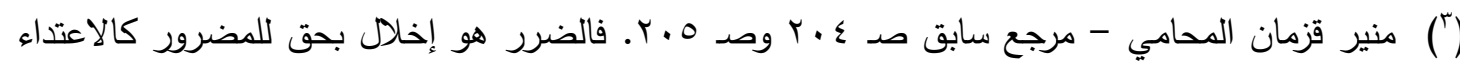

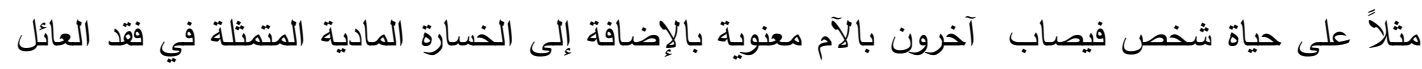
وفقد السند الذي كان سيقوم على إعانتهم طوال فترة حياته وهو أمر أكيد حيث أنه يمثل فوات فئل فرصة فألى فأجاز

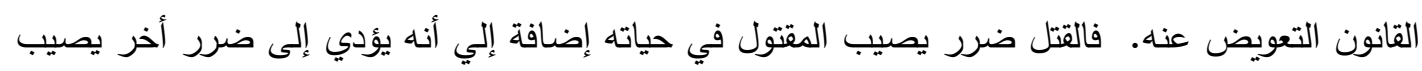

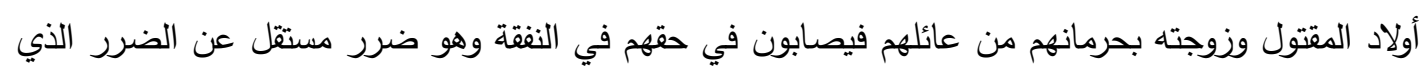
أصاب المقتول نفسه

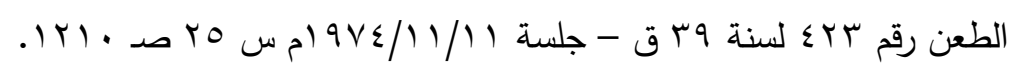

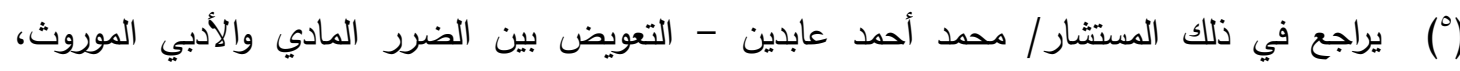

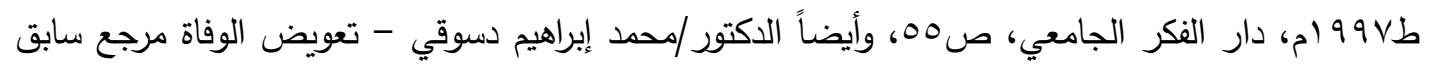

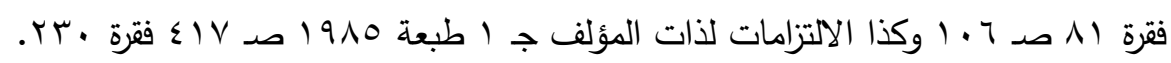

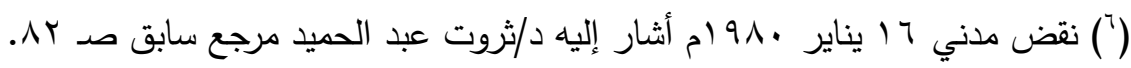

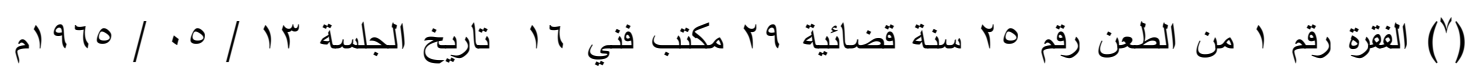

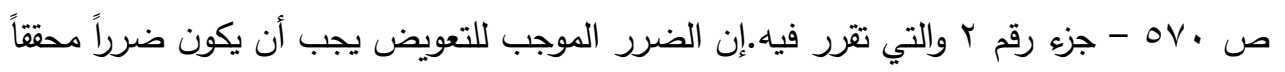

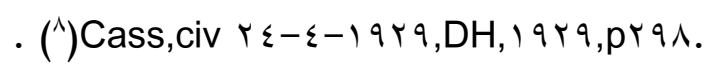


حدوث الضرر فإذا لم يقم الدليل على أن الضرر الذي أصاب المضرور الأصلي قد أخل

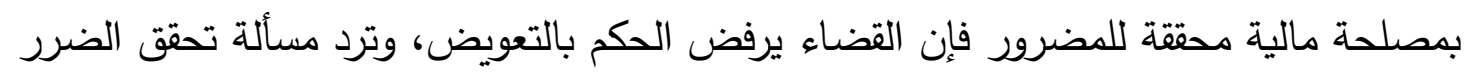

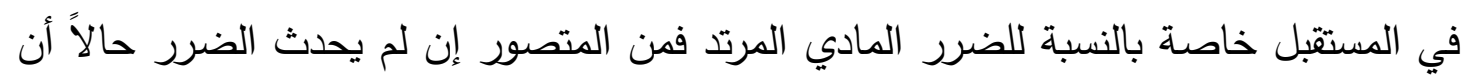

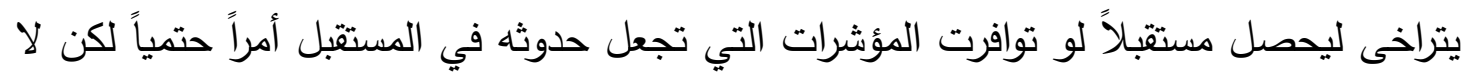

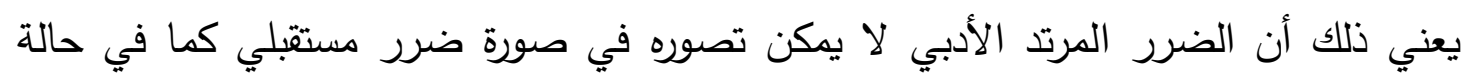

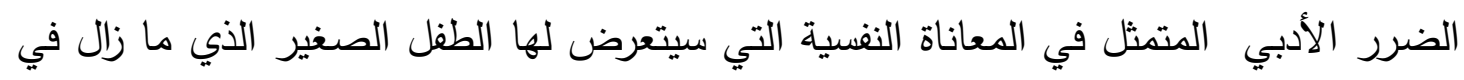

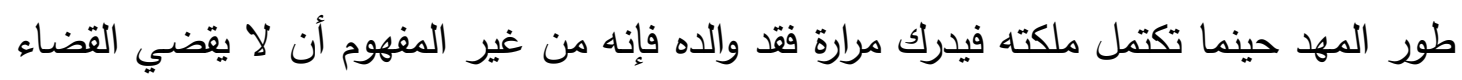

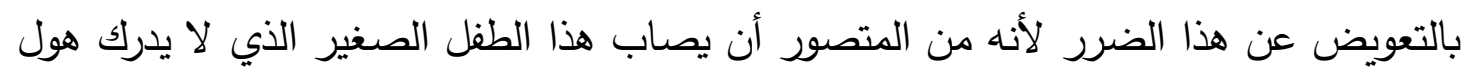

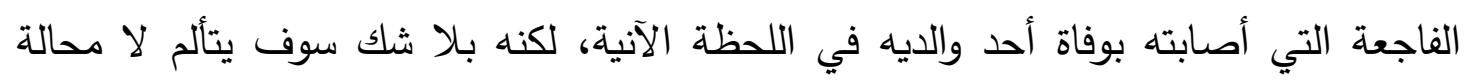

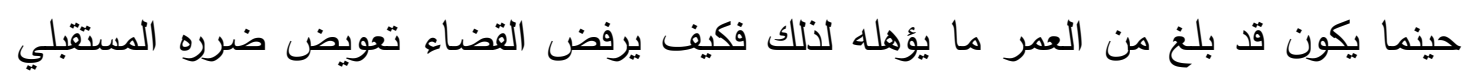

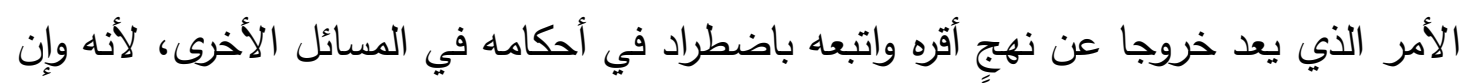

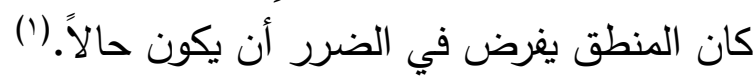
لكن ليس هناك ما يمنع أن يتأخر حدوثه في المستقبل كما لو كان المضرور بالارتداد

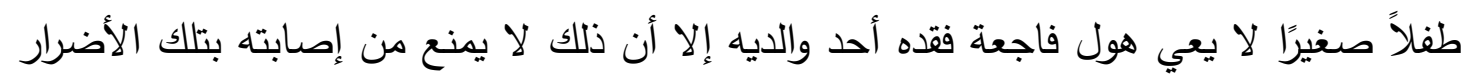

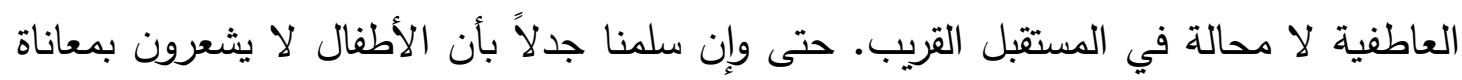

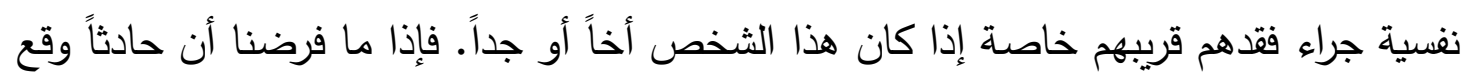

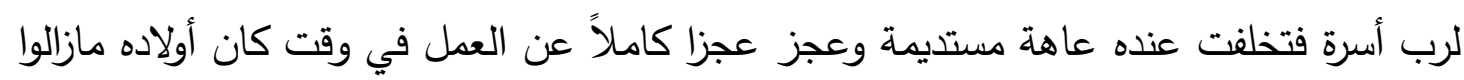
صغاراً لا يدركون ما وقع لوالدهم فإن التساؤل يتجلى عما إذا كان من الجائز الحكم لهؤلاء الهاء

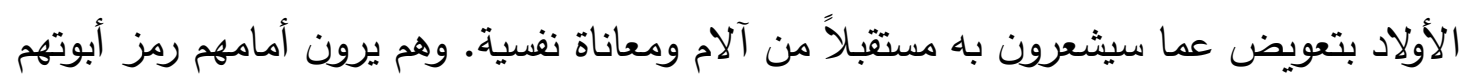

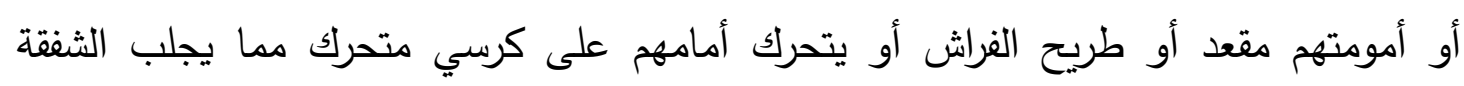
والحزن الثديد

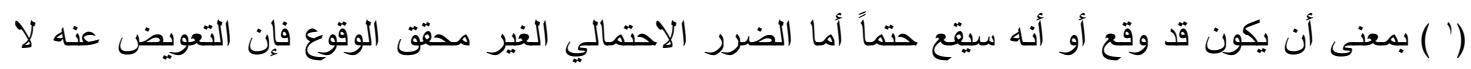

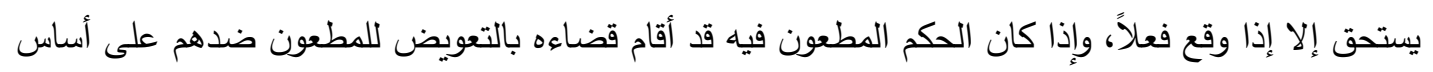

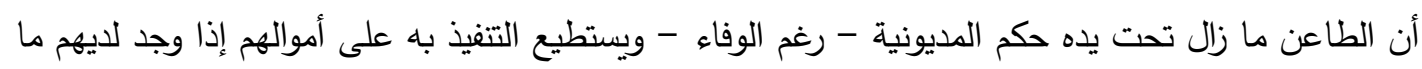

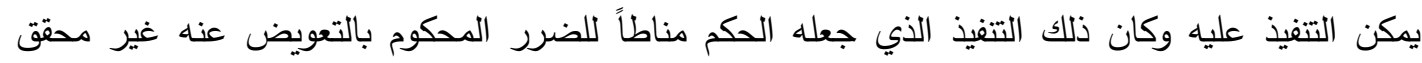

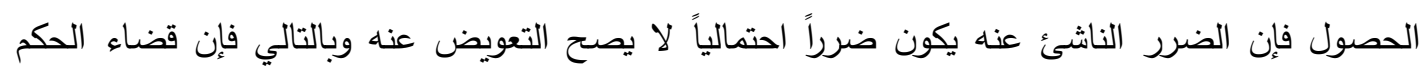
بالتعويض عن هذا الضرر يكون مخالفاً للقانون. 


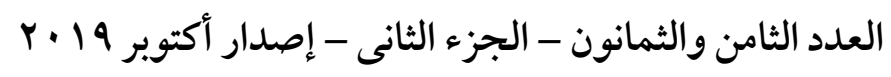

نلاحظ أن القضاء في مصر لا يقر لمثل هؤلاء حق التعويض عن الضرر الأدبي

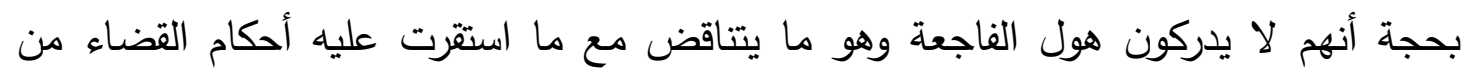

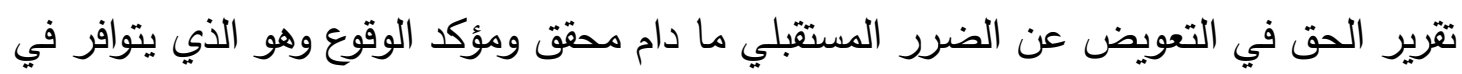

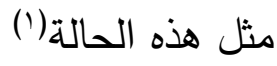

(') وهو الأمر الذي يخالفه البعض في الفقه د/ ثروت عبد الحميد - مرجع سابق صـ عـ., فقرة • عص.9,

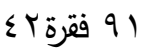




\section{خاتمة وأهم نتائج وتوصيات البمث}

يتقدم الباحث ببعض التوصيات التي يري في إضافتها والعمل بها ما يفسح المجال أمام

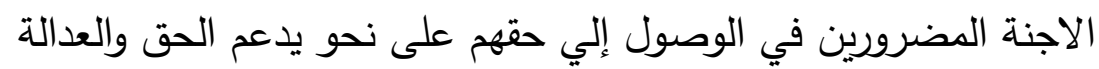

اولاً : الأجنة تتمتع بحقوق معنوية أو ادبيه لهم لذا تطلب الأمر وضغ نصوص تقرر حق

التعويض عن الضرر المادي والأدبي" المعنوي" الذي يصيب الأجنه في بطون امهاتهم .

ثانياً : مبلغ التعويض عن هذه الأضرار هو حق خالص للجنين في تعويض الأضرار المعنوية أو الأدبية التى تصيبه اثناء فترة الحمل وتتعكس على شخصيته وتكوينه النفسي بعد مولده .

ثالثاً :اعتماد مبلغ الغرة المقرر في الثريعة الاسلامية كتقدير عن تعويض ضرر الموت للجنين

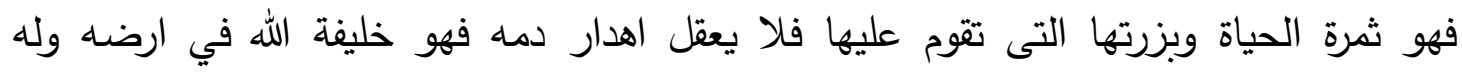
خصوصية خاصة الامر الذي يحتاج الى التوصية بمزيد من الحماية

رابعاً : مناشدة القضاء للعدول عما ذهب إليه من رفضه التعويض عن الضرر الأدبي إذا ما

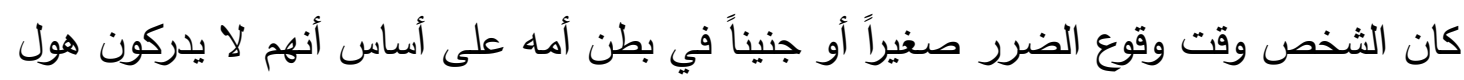

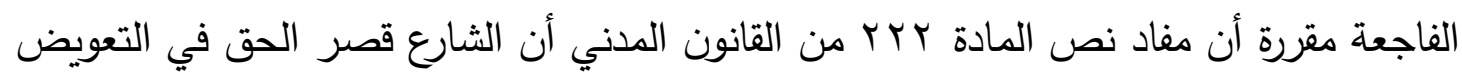

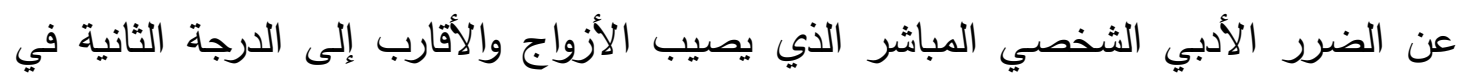

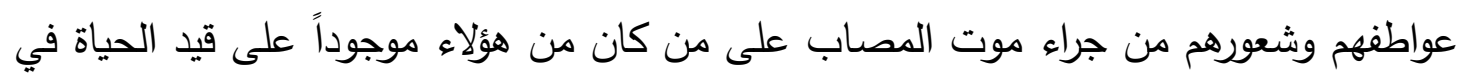

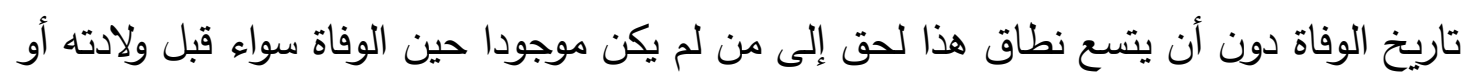

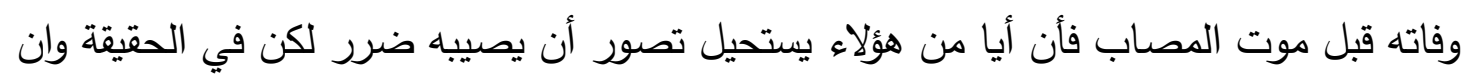

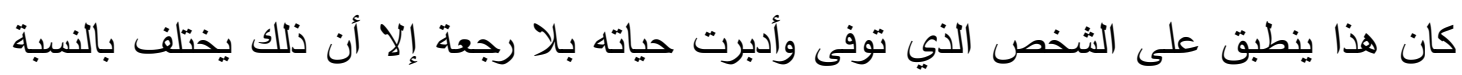

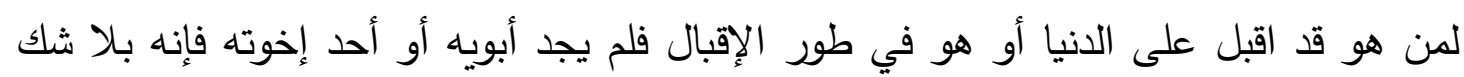

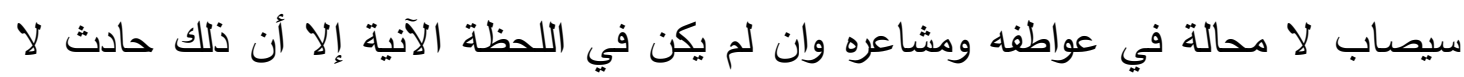

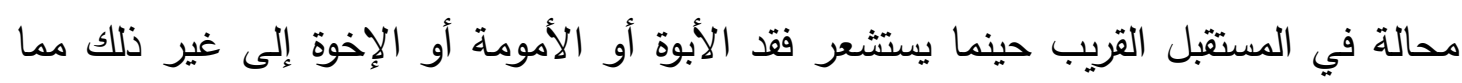

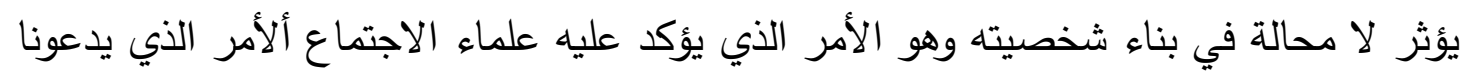

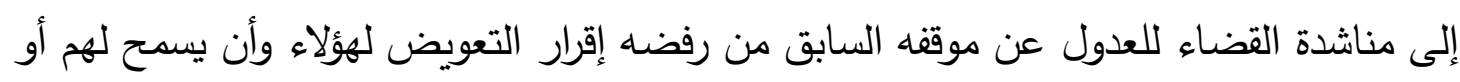
لمن يمثلهم في مقاضاة المسئول للحصول على تعويض يجبر أضرارهم المستقبلية الأكيدة

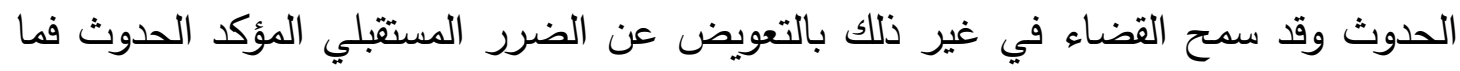

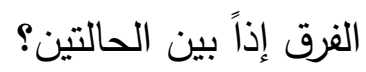


وأخيراً فإن هذا جهد المقل فإن كنت قد وفقت في ذلك فهذا بفضل الله تعالى وما أحسن عبارة عبد الرحيم البيساني إلى العماد الأصفهاني معتذراً عن كلام استدركه حيث قال: إني رأيت أنه لا يكتب إنسان كتاباً في يوم إلا قال في غده.لو غير هذا لكان لكان أحسن،

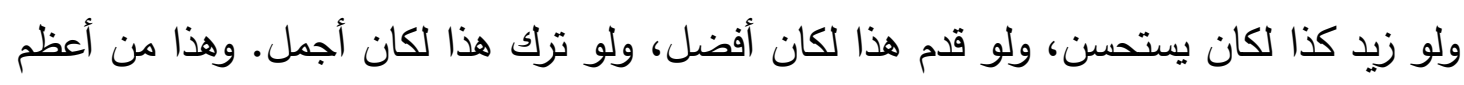

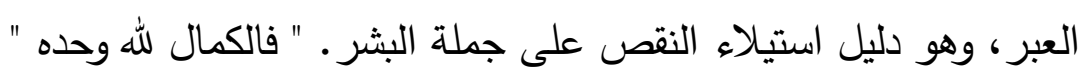
وآخر دعوانا أن الحمد لله رب العالمين 


\section{قائمة المسادر والمراجع والرسائل العامية}

\section{أولاً: القرآن الكريم (جل من أنزاله)}

- الجامع لأحكام القرآن " للإمام شمس الدين ابي عبدالله محمد بن احمد بن ابى بكر بن فرج الانصاري القرطبي طبعة دار الكتب جل

ثانيكا : كتب السنة :

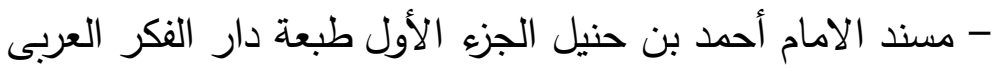

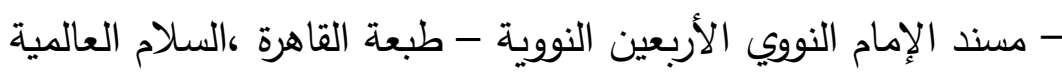

كتب الاغة :

- المصباح المنير ، احمد بن محمد اليومي ، مكتبة البنان ، بيروت ط اسنة 191V م.

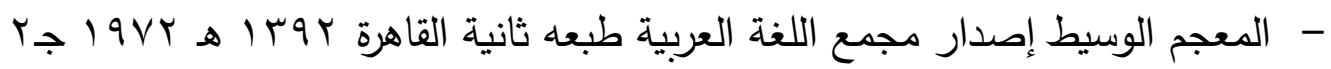

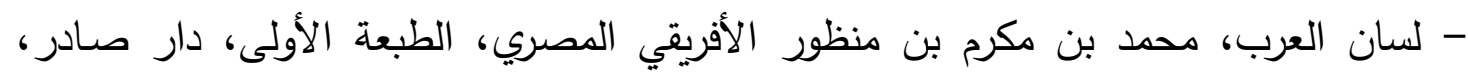

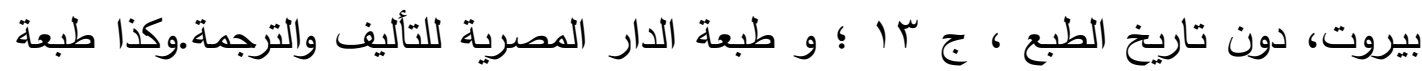

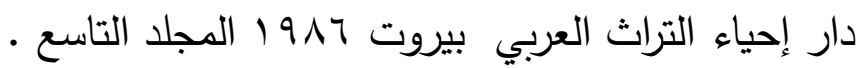

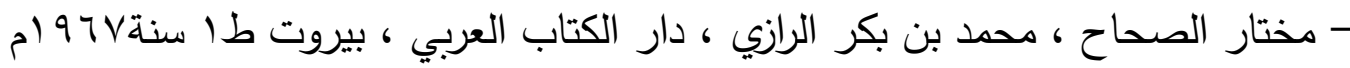
كتب الفقه :

- أصول السرسخي لأبي بكر محمد بن أحمد بن أبي سهل السرخسي تحقيق ابو الوفا الافغاني

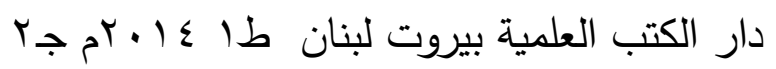

- الاشباه والنظائرالمؤلف: عبد الرحمن بن أبي بكر، جلال الدين السيوطي (المتوفى: 1) (9ه)

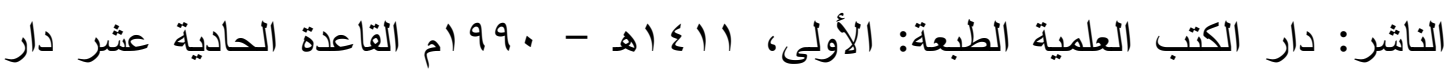

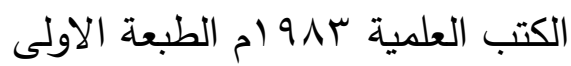
- البحر الرائق كنز الدقائق المؤلف: زين الدين ابن نجيم الحنفي - ابن عابدين، دار المعرفة بيروت طس r 1999 ـ ـ 
- البناية شرح الهداية المؤلف: أبو محمد محمود بن أحمد بن موسى بن أحمد بن حسين

الغيتابى الحنفى بدر الدين العينى جrا (المتوفى: 100هـ) الناشر : دار الكتب العلمية

-التقرير والتحبير ابن موفق ، ابو عبدالله شمس الدين محمد ، ، دار الكتب العلمية بيروت ط

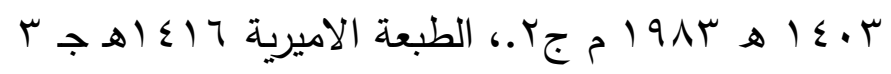

-التلويح على التوضيح المؤلف: سعد الدين مسعود بن عمر التفتازاني (المتوفى: بهوهـ) الناشر : مكتبة صبيح بمصر الطبعة: بدون طبعة وبدون تاريخ عدد جـ r. - الحاوي الكبير للماوردي في فقه مذهب الإمام الثافعي وهو شرح مختصر المزني المؤلف: أبو الحسن علي بن محمد بن محمد بن حبيب البصري البغدادي، الثهير بالماوردي ، جـ I - - الخرشي على مختصر سيدي خليل وحاشية الثيخ على العدوي على الخرشي ، دار الكتاب الاسلامي ، القاهرة جـي جـ

- المبسوط شمس الدين السرسخي المؤلف: محمد بن أحمد بن أبي سهل شمس الأئمة

$$
\text { السرخسي المتوفى: rیءء دار المعرفة بيروت ج؟ }
$$

- المجموع شرح المهذب المؤلف: أبو زكريا محيي الدين يحيى بن شرف النووي (المتوفى:

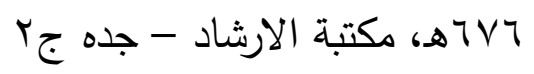

- - المدونة الكبرى ، لامام دار الهجرة المام مالك بن انس الصبحي رواية. الامام سحنون بن سعيد التتوخى عن الامام عبد الرحمن بن القاسم. العتقى عن الامام مالك بن أنس طبعة

مصطفى البابى الحلبي وأولاده ، سبل السلام للصنعانى جـا، جـ 17

- - المدونة الكبرى ،لامام مالك بن انس، طبعة دار الفكر ، جـ ،

- المغني لابن قدامة ـ المؤلف: أبو محمد موفق الدين عبد الله بن أحمد بن محمد بن قدامة

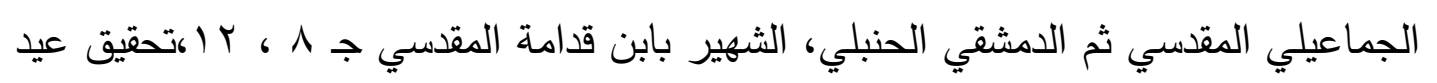

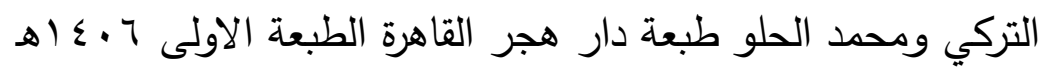

-بدائع الصنائع الكساني تصوير دار الكتب العربية المؤلف: علاء الدين، أبو بكر بن مسعود

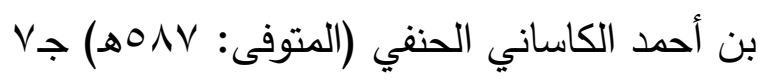

- بداية المجتهد أبو الوليد محمد بن أحمد بن محمد بن أحمد بن رشد القرطبي الثهير بابن رشد

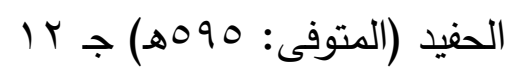

- حاشية الدسوقي على الثرح الكبير ، شمس الدين الدسوقي جء مطبعة دار احياء الكتب العربية 


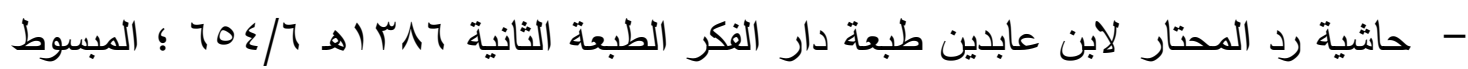

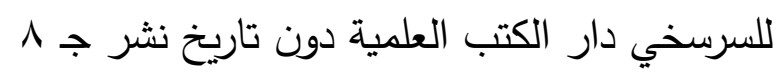

- غمز عيون البصائر شرح الأشباه والنظائر لأحمد بن محمد الحنفي الحموي ط دار الكتب

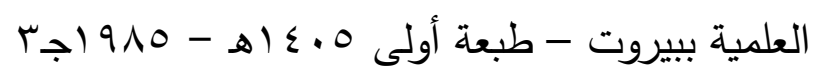

-فتح المبين ، لثهاب الدين ابى عباس احمد بن محمد بن على بن حجر الهيثمي ،دار احياء

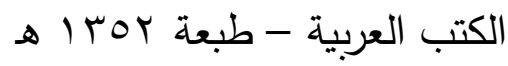

-مواهب الجليل للحطاب جr ، طبعة 1901 مطبعة مصطفى الخلبي ؛ فتح القدير للكمال بن

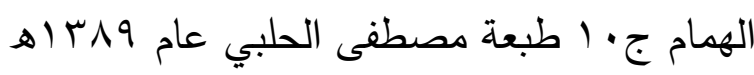

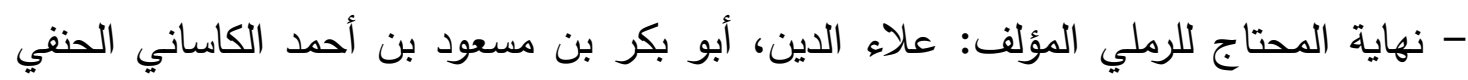

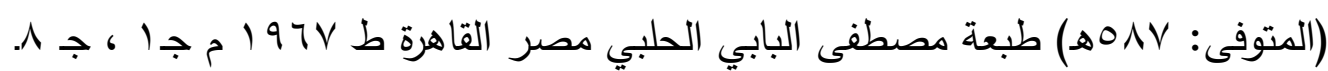

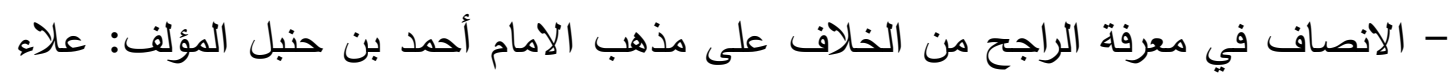

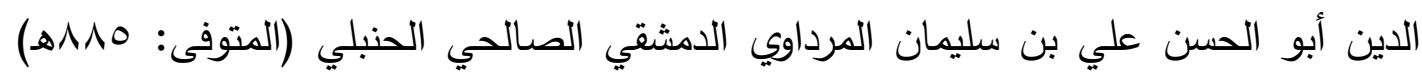

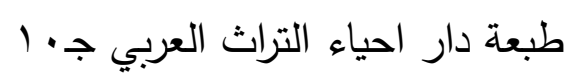

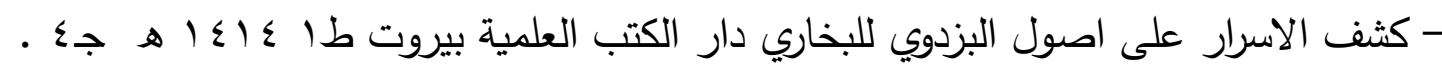
- كثف الأسرار عن اصول البزدوي طبعة دار الكتاب العربي المؤلف: عبد العزيز بن أحمد بن

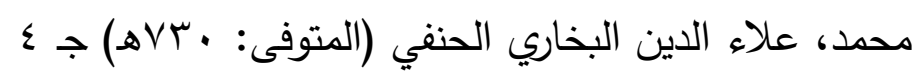

\section{كتب الفقة المعاصرة}

- أصول الفقه عبد الوهاب خلاف مكتبة الدعوى الإسلامية ، شباب الأزهر الطبعة الثامنة دون

$$
\text { تاريخ طبع }
$$

- أصول الفقه في الاسلام محمد ابو زهرة طبعة دار المعارف مصر .

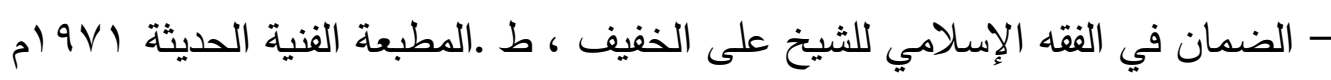
المدخل للفقه الإسلامى، للدكتور محمد سلام مدكور ، طبعه مكتب عبد الله وهبه القاهرة طبعة

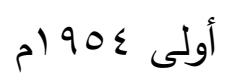

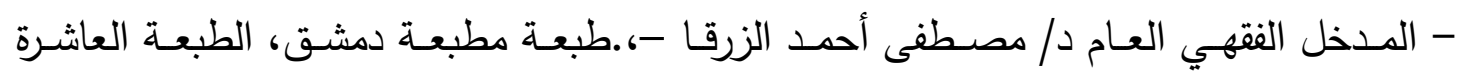

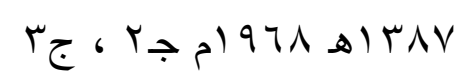

- المسئولية المدنية والجنائية في الثريعة الإنلامية محمود شلتوت - طبعه مطبعة الأزهر

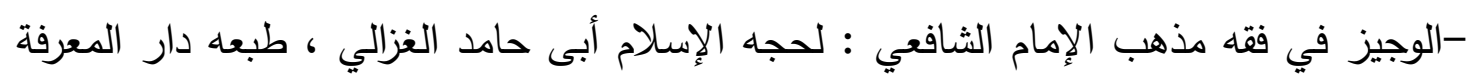

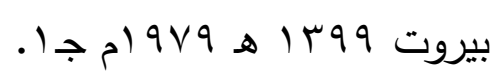


-الضمان في الفقه الإسلامي ، الثيخ علي الخفيف الناشر: دار الفكر العربي السلسلة طبعة r. 10 -شرح المجلة، لسليم بن رستم باز اللبناني، طبعة المطبعة الأدبية، بيروت ه^ه ام طبعة ثانية شرح المادة 19

\section{كتب القانون}

- - إسماعيل غانم محضرات في نظري الحق طبعة 974 ام القاهرة

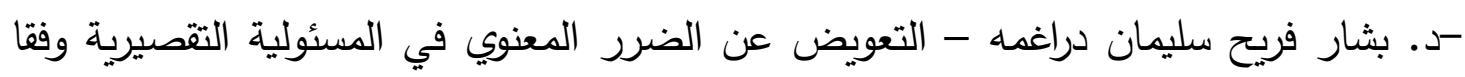

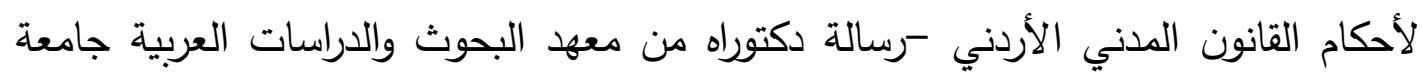

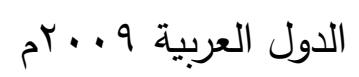

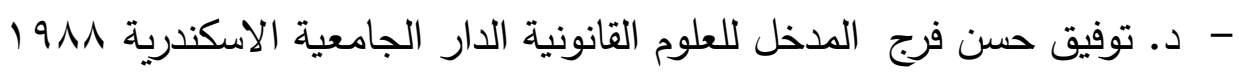
- د. ثروت عبد الحميد "مدى المسؤولية عن الخطأ في اكتثاف تشوهات الجنين وأمراضه

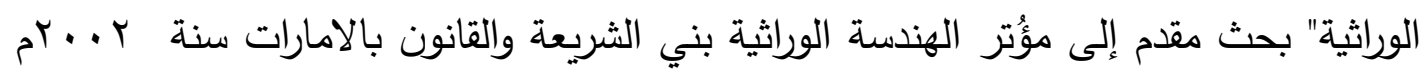
المجلد الثالث

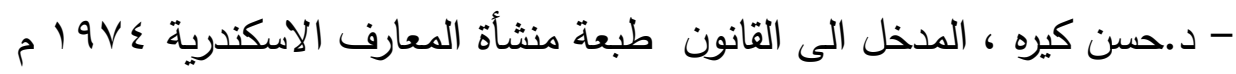

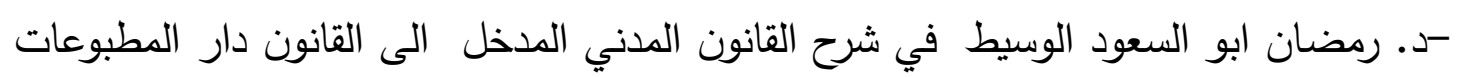

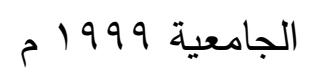

-د.عبد الرازق السنهورى :الوجيز فى شرح القانون المدنى , الجزء الأول , نظرية الألتزام بوجه عام , الطبعة الثانية , تنقيح المستشار مصطفى الفقى , الجزي الأول,. - د عبد الرازق السنهوري الوسيط في شرح القانون المدني الجديد ، جا مصادر الالتزام ،

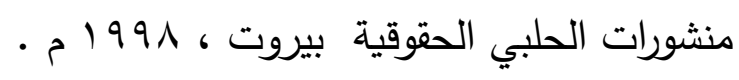

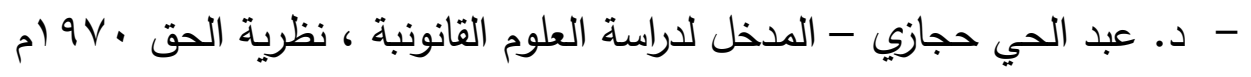

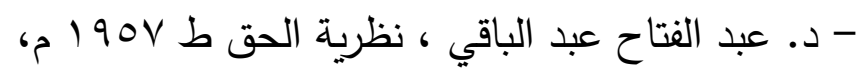

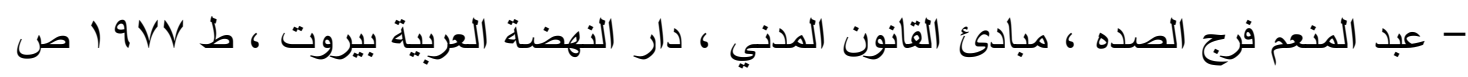
rIT

- د عبد المنعم فرج الصده، اصول القانون دار النهضة العربية بيروت ط 971 ام ام

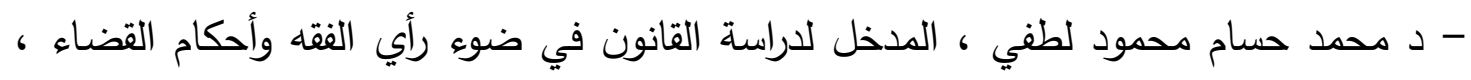

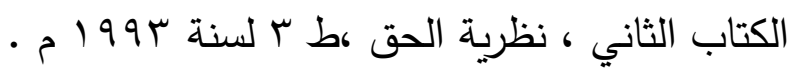

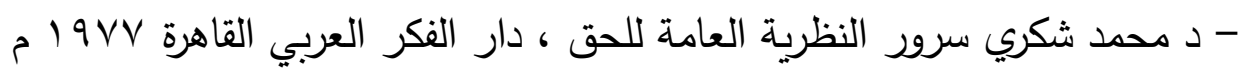


- د محمد محمود عبدالله ، المدخل الى علم القانون، طبعة 1999 م - د. محمد فتح الله النشار ،حق التعويض المدني بين الفقه والقضاء الإسلامي والقانون المدني

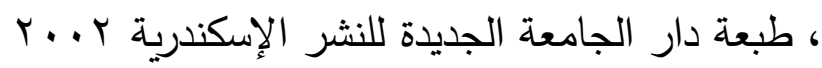
-د. مصطفى محمد الجمال القانون المدني في ثوبه الإسلامي مصادر الالتزام ط الأولى بدون تاريخ طبع الفتح للطباعة والنشر .

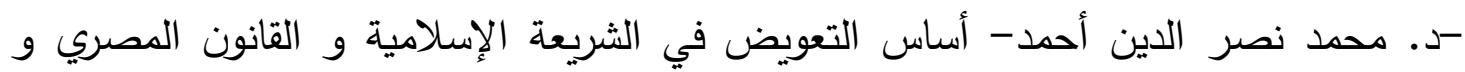

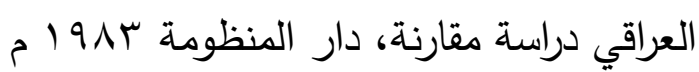

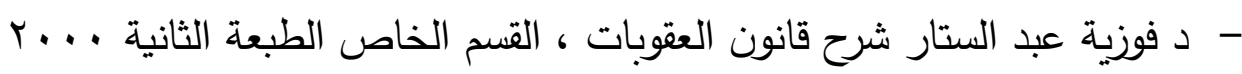

- د. منصور مصطفى منصور ، الدذخل للعلوم القانونية مجلد ب طبعة (197 م مرك -د محمود نجيب حسني شرح قانون العقوبات القسم الخاص طبعة ז191ام دار النهضة العربية - د. نعمان جمعه دروس في نظرية الحق ط 9 - 19 دون ذكر دار نشر - د. هلالي عبد اللاه أحمد "التزامات الحامل نحو الجنين بين التجريم الجنائى والاباحة ،طبعة

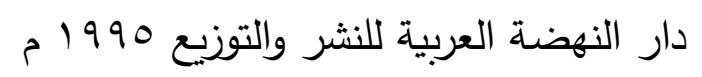
د. محمد إبراهيم دسوقي تعويض الوفاة للاصابة الناتجة ، دار النهضة العربية للطبع والنشر

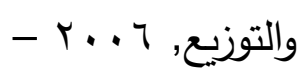

- د. محمد إبراهيم دسوقي الالتزامات جـ البعة طبعة 1910.

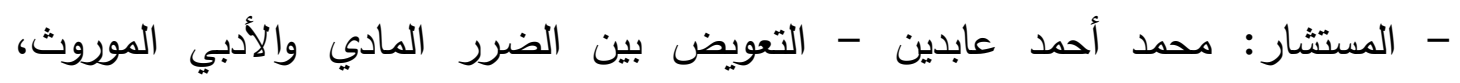

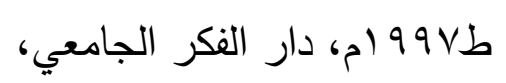
-د . محمد حسن عبد الرحمن - مصادر الالتزام دراسة مقارنة - طץ، • • + ب، دار النهضة العربية، القاهرة، مدان -د. مصطفى مرعي - المسئولية المدنية في القانون المصري ، مطبعة نوري ،بساول19 م

\section{الدوريات العربية}

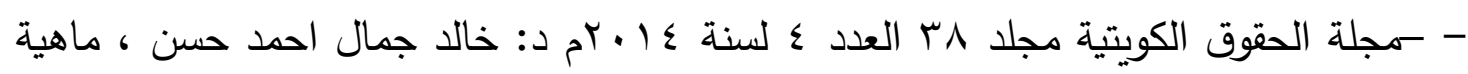
الحقوق المدنية للجنين -ـراسة مقارنة

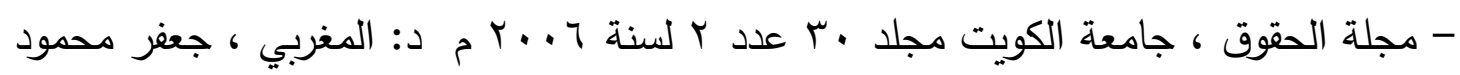

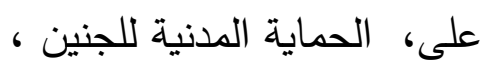


- مجلـة الأحكام العدليـة تأليف لجنـة مـن كبار ديوان الأحكام العدليـة طبعـة مطبعـة شعاركو بيروت

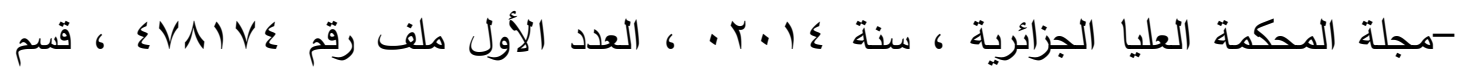
الوثائق و الدراسات القانونية و القضائية ، الرويبة 0 ـ ـ + ،

-المستحدث من المبادئ التى اقرتها الدوائر المدنية بمحكمة النقض المكتب الفني 990

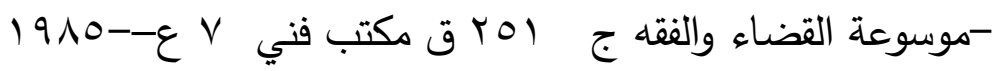
-مجلة البحث العلمي والتراث الإسلامي، كلية الثريعة، جامعة الملك عبد العزيز، العدد

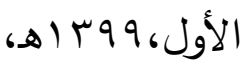

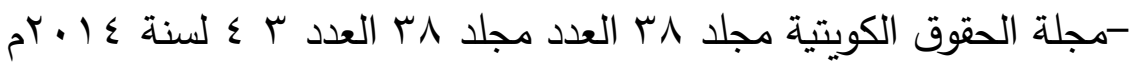

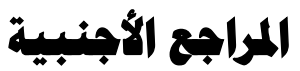

-Boris Starck Droit civil obligationParis I $9 \vee \mathrm{Y}$

-Le Tourneau (PH.), Droit de la responsabilité et des contrats, D. Y . ., ,Mazeaud (H.L.)Taité de la responsabilité civile, T. Y, тe éd.

-Mazeaud (H.J.) et Chabas (F.), Leçons de droit civil...

-MAZEAUD et (F) CHABAS,lecons de droit civil,T , rv,les personnes,les inacapacites ,ved Monchrestien,paris, $19 \wedge \uparrow$,.

-COUR. Adm. Appel paris r-eme ir juin $r \ldots r$

مواقع ذات صلة على شبكة الانترنت

http://www.egynews.net/wps/portal/newsdetails?WCM_GLOBAL_CONTEXT=/ wps/wcm/connect/migration/ertu/news_locals/ $/ . \Lambda 1.171 \leqslant 01.01 Y Y . Y \leqslant 9 \leqslant$

http:

//www.islamonline.net/servlet/Satellite?c=ArticleA_C\&cid= $1 / 9 \Gamma \cdot \leq 97)$. rVY\&pagename=Zone-Arabic-Shariah\% $\%$ FSRALayout

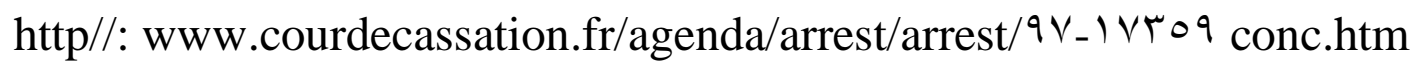


تعويض الأجنة عن الأضرار المدنية دراسة مقارنة بين القانون المدني المصري ، والشريعة الإسلامية

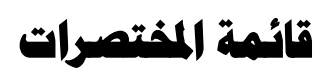

D. Recevil dalloz

Gaz.Pal Gazette des Palais

J.C.P. Juris-Classeur Periodique (la semaine juridque).

S.- Receuil Sirey

Somm Sommaire.

Bull. Bulletin des arrest du la cour de cassation

Bull. Civ. Bulletin Civil

Cass. Civ. Cour de Cassation, chambre Civile

Cass. Cim.. Cour de Cassation, chamber Criminelle

P. page

N Numéro

op. cit - ouvrage cite 